\author{
UNIVERSIDADE DE SÃO PAULO \\ FACULDADE DE FILOSOFIA, LETRAS E CIÊNCIAS HUMANAS \\ DEPARTAMENTO DE HISTÓRIA \\ PROGRAMA DE PÓS-GRADUAÇÃO EM HISTÓRIA SOCIAL
}

LUIZ HENRIQUE SOUZA DE GIACOMO

\title{
A 'restauração republicana' de Augusto: Discurso romano, alteridade oriental e teatrocracia política
}

(VERSÃO CORRIGIDA) 


\section{UNIVERSIDADE DE SÃO PAULO \\ FACULDADE DE FILOSOFIA, LETRAS E CIÊNCIAS HUMANAS \\ DEPARTAMENTO DE HISTÓRIA \\ PROGRAMA DE PÓS-GRADUAÇÃO EM HISTÓRIA SOCIAL}

Luiz Henrique Souza de Giacomo

A 'restauração republicana' de Augusto: discurso romano, alteridade oriental e teatrocracia política

\section{(VERSÃO CORRIGIDA)}

Dissertação apresentada ao Programa de PósGraduação em História Social do Departamento de História da Faculdade de Filosofia, Letras e Ciências Humanas da Universidade de São Paulo como requisito para a obtenção do título de mestre.

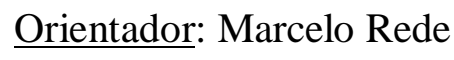




\section{FOLHA DE APROVAÇÃO}

Luiz Henrique Souza de Giacomo

A 'restauração republicana' de Augusto: discurso romano, alteridade oriental e teatrocracia política.

Dissertação apresentada ao Programa de PósGraduação em História Social do Departamento de História da Faculdade de Filosofia, Letras e Ciências Humanas da Universidade de São Paulo como requisito para a obtenção do título de mestre.

Área de concentração: História Social

Aprovado em:

\section{Banca Examinadora}

Professor(a) Doutor(a)

Instituição

Assinatura

Professor(a) Doutor(a)

Instituição

Assinatura

Professor(a) Doutor(a)

Instituição

Assinatura 
Àqueles que amo. 


\section{AGRADECIMENTOS}

Primeiramente, tenho muito a agradecer à minha família, que sempre foi o meu principal suporte. Tenho muito a agradecer à educação recebida, a qual me possibilitou abrir muitas portas. Ao carinho com o qual sempre fui criado e que continuei sempre recebendo mesmo estando longe de casa, muito importante num período de estranhezas como o de se mudar de uma cidade de médio porte em Minas para a maior do país, São Paulo.

À minha mãe devo agradecer, primeiramente, por ter acreditado que tudo seria possível, por sempre me incentivar a sonhar e correr atrás dos meus sonhos e escolher a educação como o caminho de realizações. Ela sempre foi um modelo de garra e perseverança para mim, sendo sempre alguém a ser imitada. Em segundo lugar, por ter me sustentado financeiramente durante todo o processo, algo nem sempre possível a todos.

Aos meus irmãos agradeço pelo apoio, muitas vezes mudo, para que este trabalho se concretizasse. Ao meu pai, em memória, agradeço por sempre ter me desafiado a buscar o meu melhor durante toda minha vida.

Agradeço à minha prima, Cristina, que abriu as portas de sua casa em São Paulo e me ajudou muito numa fase de adaptação e de imprevistos durante a época em que vivi nesta cidade.

À minha ex-orientadora de graduação e amiga da vida e de profissão, professora Ludmilla Savry Almeida, agradeço por ter me feito ficar encantado com a Antiguidade e transformar este período do passado em meu objeto de estudo. Também agradeço pelos primeiros incentivos a vir para a USP em busca da continuação de meus estudos e pelo carinho dedicado em todo o percurso do mestrado.

Agradecer aos meus amigos é fazer uma longa lista interminável de pessoas que de diversas maneiras estiveram presente durante esses anos, sempre me incentivando e apoiando. Àqueles que ficarem de fora da lista, não significa que não estejam em minha alma com grande carinho.

Começo por uma amiga de infância, Livia, que desde que eu falei que viria para São Paulo, me apoiou, mas também ficou triste pela distância que nos separaria. No entanto, o seu apoio foi essencial para que eu pudesse correr atrás de meus objetivos. 
À Joana, Luan e Vanessa, agradeço pelos diversos momentos de descontração que passamos juntos nessa caminhada, muito importantes para que eu pudesse distrair um pouco de Roma e viver fora dos textos, bem como também pelos constantes incentivos na execução da pesquisa.

Aos meus amigos de graduação, em especial Franciany, Letícia, Nívea e Thalles, que tiveram parte importante na minha formação enquanto historiador e que sempre me ajudaram e apoiaram na caminhada trilhada até aqui.

Ao Mateus e à Giovana, pelas trocas de conhecimento e pela amizade. À Alessandra, Edna e Aline, pelo apoio e momentos de descontração compartilhados. À Juliana, por ter sido sempre uma amiga tão alegre e permitido que através de suas aulas meu corpo aguentasse as tensões do processo de escrita de uma dissertação.

Ao Fábio, meu caro companheiro de estudos da Antiguidade e do Medievo em uma universidade mineira que pouco espaço nos lega para nossas pesquisas, pelas trocas de conhecimento e amizade.

À Andréia, meu carinho mais especial por sempre me fazer rir e incentivar minha pesquisa, desde a época da seleção, com grande confiança no trabalho final. Ao Filipe, pela grande companhia deste último ano de mestrado e pelo constante e importante incentivo para que a escrita da pesquisa fosse realizada.

Agradeço aos amigos que fiz na USP: Alan, Lucia e Rodrigo. Foram muito prazerosas as conversas, as aulas e os momentos de troca de experiências acadêmicas e de vida. Apesar da distância, encurtada pela Internet, sempre lembro com carinho dessa fase. Em especial agradeço ao Rodrigo, meu fiel companheiro de caminhada, desde a entrevista até a fase da defesa, sempre compartilhando informações preciosas, conselhos importantes para o desenvolvimento da pesquisa e pela amizade construída não só nos corredores da USP.

Aos meus professores na pós-graduação Norberto Guarinello, Laura de Mello e Souza e Maria Luiza Corassin, pelos ensinamentos no interior das salas de aula, os quais me foram muito enriquecedores como profissional. Em especial a esta última, que me proporcionou a grande oportunidade de ser seu aluno em um curso sobre Augusto e que tanto me fez crescer nos estudos sobre meu tema. À professora Corassin, mais uma vez, e ao professor Carlos Augusto Machado pelos conselhos da qualificação, os quais fizeram minha pesquisa de fato alavancar e tomar o formato que aqui apresento.

E por último, mas não menos importante, de forma alguma, tenho muito a agradecer ao meu caro orientador, Marcelo Rede. Mais que um profissional de primeira linha, um homem exemplar. Aprendi muito nos diversos momentos em que estive em sua presença. 
Obrigado pela oportunidade, pela confiança, pelos conselhos, pela amizade e, principalmente, pela grande paciência, muito requisitada durante o processo de pesquisa.

Também agradeço ao povo brasileiro pelo apoio financeiro propiciado através da bolsa de mestrado concedida pela CAPES. 


\section{RESUMO}

O presente exercício reflexivo visa fazer uma análise do papel político desempenhado por César Augusto durante a construção, a consolidação e a legitimação do sistema político do Principado romano. Tomaremos como base analítica os discursos e as ações de Augusto na cena política romana em prol da restauração da República. Para tanto, propomo-nos abordar o modo como o príncipe se apropriou da artimanha de construção dos estereótipos de seus rivais, Marco Antônio e Cleópatra, no intuito de elevar sua própria posição na cena política romana. A forma como ele se utilizou de discursos do eu e do outro permeia nosso olhar, sobretudo com relação ao mundo oriental que serviu como elemento num plano discursivo e prático de difamação de seus rivais e de apresentação deles como uma ameaça à República romana, a qual ele pretendia salvaguardar e elevar aos melhores tempos.

Palavras chave: Augusto. Marco Antônio. Cleópatra. Oriente. Restauração da República. 


\begin{abstract}
This reflective exercise aims to analyze the political role performed by Caesar Augustus during the construction, consolidation and the legitimacy of the political system of the Roman Principality. We will take as analytical basis the discourses and actions of Augustus in the Roman political scene on behalf of restoration of the Republic. Therefore, we propose to board the way how the Prince appropriated the trick of construction of stereotypes of his rivals, Marc Antony and Cleopatra, in order to raise his own position in the Roman political scene. The way he used speeches of me and other permeates our gaze, especially concerning the Eastern world that served as an element in a discursive and practical plan to defamation his rivals and their presentation as a threat to the Roman Republic, which he intended to safeguard and raise the best times.
\end{abstract}

Keys-word: Augustus. Marc Antony. Cleopatra. Orient. Restauration of Republic. 


\section{RÉSUMÉ}

Le présent exercice réflexif prétend faire une analyse du rôle politique exercé par César Auguste pendant la construction, la consolidation et la légitimation du système politique du Principat romain. On prendra pour base analytique les discours et les actions d'Auguste dans la scène politique romaine en faveur de la restauration de la République. Pour ce faire, on se propose d'aborder la façon dont le prince s'est approprié de l'artifice de la construction des stéreótypes de ses adversaires, Marc Antoine et Cléopâtre, dans le but de hausser sa propre position dans la scène politique romaine. La manière dont il a employé les discours du moi et de l'autre traverse notre perspective, surtout en ce qui concerne l'Orient qui a servi d'élément dans un plan discursif et pratique de diffamation de ses adversaires et de leur présentation en tant que ménaces à la République romaine, laquelle il prétendait sauvegarder et ériger aux meilleurs temps.

Mots-clés: Auguste. Marc Antoine. Cléopâtre. Orient. Restauration de la Republique. 


\section{SUMÁRIO}

Introdução

Capítulo 1 - Otaviano, Marco Antônio e a República .................................................. 21

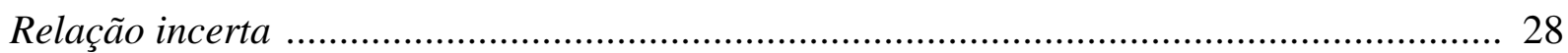

A degeneração dos padrões civis e o compromisso com a República ................................. 34

Capítulo 2 - Augusto e a 'ameaça da realeza' ............................................................. 65

Entre romanos e estrangeiros: alteridade e identidade ................................................. 67

O retrato de Cleópatra: uma ameaça aos romanos? ......................................................... 78

$\underline{\text { Capítulo } 3}$ - O comportamento social de Augusto ......................................................... 103

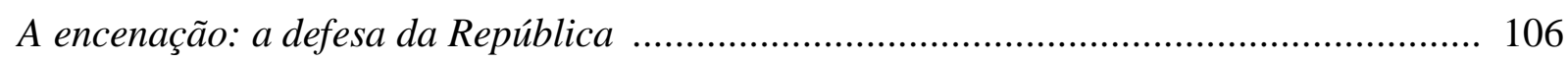

Cargos, poderes e honras de Augusto .................................................................... 122

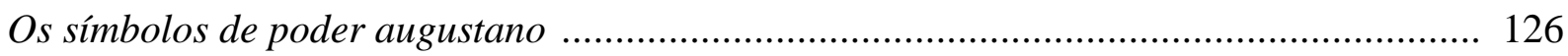

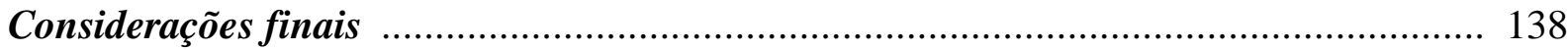

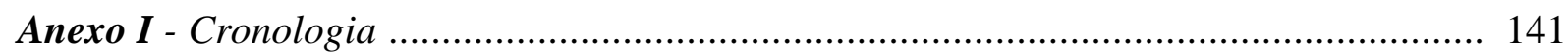

Referências Bibliográficas ............................................................................... 143 


\section{$\underline{\text { INTRODUCẼ̃O }}$}

Roma, a partir do século II a.C., se tornou uma grande cidade que detinha o domínio de uma grande porção das terras às margens do mar Mediterrâneo. De uma pequena aldeia no Lácio ela se tornou a capital de um grandioso império. Com isso, passou a ser o destino de muitos daqueles que viajavam pelo mundo mediterrânico, independente dos motivos (econômico, político/diplomático ou outro). Um homem que, no último século da República, decidisse andar pelas ruas e vielas da Urbs veria que o cenário urbano estava passando por uma grande transformação, cada vez mais o espaço público se tornava um ambiente de expressão de toda a grandiosidade de Roma e dos homens romanos, havendo uma profusão de objetos de artes (estátuas e utensílios cotidianos, por exemplo), de novos edifícios e obras públicas, locais que também se tornaram vetores de ações discursivas nas disputas políticas.

A cidade é um cenário de espaços múltiplos, onde o homem estabelece suas relações em sociedade, com as divindades e com a natureza. É onde diversos discursos estão presentes, onde o tempo está marcado. São espaços onde observamos, assim, o intercruzamento entre a materialidade, a sociabilidade e a sensibilidade. Espaços que passaram por grandes modificações não apenas pelas ações cotidianas de seus cidadãos e visitantes, mas também por aqueles que detinham o poder político e religioso (PESAVENTO, 2007, p.11-23).

A Roma da época de Otaviano/Augusto nos legou muitos fragmentos arqueológicos arquitetônicos, numismáticos, de utensílios e objetos cotidianos, a partir dos quais podemos, juntamente com a tradição literária, construir uma leitura sobre as ações dos homens desse período, mais do que daqueles de séculos anteriores, por exemplo. Temos a possibilidade de conhecer o cenário em que o príncipe agiu. Espaço o qual, pela própria ação de Otaviano/Augusto ${ }^{1}$, passou por transformações durante sua ação política e serviu de ambiente

\footnotetext{
${ }^{1}$ Os historiadores se referem ao homem que conhecemos como Augusto de diversas maneiras. De acordo com Corbier, "o personagem que os historiadores chamam, por convenção, de Otávio, antes de 44, de Otaviano, de 44 a 27, e de Augusto, de 27 a.C, até sua morte em 14 d.C., nascido C(aius) Octavius, tornou-se, por adoção testamental, C(aius) Julius Caesar Octavianus" (CORBIER, 1992/1993, p.169). As fontes, geralmente, o denominam de César. Optamos aqui por esse formato de Otaviano/Augusto quando estivermos nos referindo ao
} 
para a sua mise en scène. Como Belayche aponta, a Urbs era um lugar de poder e as disputas políticas da República, como permaneceu durante o principado de Augusto, apesar de sua posição individual, foram traduzidas para esse espaço urbano (BELAYCHE, 2001, p.3).

Estrabão, um escritor da época de Augusto, que narrou suas viagens pelo Mediterrâneo em sua obra 'Geografia', se dedicou também a descrever Roma e, assim, ele nos apresenta a grande transformação urbanística pela qual o Campo de Marte, antiga região militar romana, estava passando naquela época, e nos descreve um dos edifícios públicos mais imponentes da Urbs, o mausoléu de Augusto:

\begin{abstract}
"O mais notável de todos [os monumentos do Campo de Marte em homenagem a homens e mulheres ilustres] é aquele que chamamos de Mausoléu, imponente túmulo construído sobre uma alta base de mármore branco às margens do rio, recoberto até o cume de árvores sempre verdes e dominando em seu topo uma estátua de bronze de César Augusto. Neste monumento foram depositadas as cinzas do imperador, de seus parentes próximos e de seus amigos íntimos, e nos fundos se estende um vasto bosque sagrado que oferece admiráveis caminhadas" (ESTRABÃO, Geografia, V, 3.8).
\end{abstract}

O autor, no entanto, não descreve que diante do mausoléu de Augusto existiam duas placas de bronze e que nelas estavam gravadas o texto epigráfico que conhecemos como Res Gestae diui Augusti. Esse documento era uma apresentação, feita pelo próprio príncipe, de seus feitos em prol do Senado e do povo de Roma. Logo no início temos:

\footnotetext{
"Aos dezenove anos, formei um exército por minha iniciativa e às minhas custas. Com ele restituí a liberdade à república oprimida pelo domínio de uma facção. Por isso, o senado admitiu-me a sua ordem com decretos honoríficos, ao mesmo tempo concedendo-me, no consulado de C. Pansa e A. Hírcio, a prerrogativa de sentenciar dos cônsules, e entregou-me o poder. Ordenou ainda que, sendo eu pró-pretor, juntamente com os cônsules providenciasse para que a república não sofresse qualquer desgaste. O povo, no mesmo ano, fez-me cônsul, já que os dois cônsules haviam tombado numa guerra. Fez-me também triúnviro com a incumbência de que a república houvesse de se consolidar.” (Res Gestae, I, 1).
}

Como o próprio príncipe aponta logo no princípio de suas res gestae, ele estava agindo em prol da República contra aqueles que queriam o seu mal. Ele se põe como um romano em função do bem coletivo, da ciuitas romana, e que foi através dessa ação virtuosa que ele ascendeu politicamente e que foi nomeado triúnviro, um dos três homens responsáveis por restituir a República. Temos nesse pequeno fragmento inicial explicitado o principal discurso de Augusto, o da restauração da República, e que o seu poder não era uma usurpação dos a.C.. 
poderes das magistraturas, mas uma honra concedida por suas ações pela República, algo que é desenvolvido e reforçado no interior do documento.

Contudo, como observamos ao analisar todo o texto de Augusto, ele não cita nominalmente contra quem lutava, mesmo que por meio das associações possamos saber a quem ele se referia em cada crítica. Isso é uma característica do próprio texto epigráfico que visava engrandecer Augusto e apenas seus feitos deveriam estar ali apresentados, não elaborando uma narrativa 'completa' dos acontecimentos. Gagé se refere às res gestae como texto apologético (GAGÉ, 1935, p.34), o que muito condiz com o conjunto arquitetônico do mausoléu do qual fazia parte, um documento/monumento conforme as concepções de Le Goff, ou seja, de que aquele texto ali gravado e depositado, somado ao edifício, representava uma ação do poder político e se destinava a perpetuação de uma memória específica, a das boas ações de Augusto em prol da República (LE GOFF, 2003, p.526).

Entretanto, devemos nos perguntar contra quem ele lutava para que houvesse de consolidar a República e mostrar que seus poderes não eram usurpados. A Urbs não viu em seu conjunto arquitetônico nenhuma mensagem que mostrasse um temor interno ou externo, não diretamente. O que observamos é o surgimento de diversas construções e artefatos artísticos no intuito de elevar Roma e transmitir uma mensagem de superioridade e paz romana. Para Millar, havia sim uma espécie de mensagem arquitetônica, em que o príncipe transmitiu tanto seu discurso, quanto sua posição política para o mundo físico. Uma cidade de tijolos transformada em uma cidade de mármore ${ }^{2}$ (material nobre e muito mais durável):

\begin{abstract}
"Se eles [os romanos] ainda estivessem confusos quanto à mensagem que estava sendo entregue, eles poderiam sempre passear pelo norte do Campo de Marte, passado o Saepta e o Panteão construídos por Agripa, passada a Ara Pacis, dedicada em janeiro de um grande ano ( 9 a.C.); em paralelo com isso - provavelmente dedicado ao mesmo tempo - o grandioso relógio solar traçado por Augusto com 150 metros do Campo, sua sombra fornecida por um obelisco trazido de Heliópolis, o qual o situou, com sua base, por volta de 30 metros de altura. Eles poderiam então contemplar a imensa massa do Mausoléu de Augusto, com 88 metros de base, ele foi a maior tumba romana que conhecemos (...). Em 9 a.C. o Mausoléu já continha os restos de dois membros da família imperial, Marcelo e Agripa, e em breve receberia os de Druso. Um quarto de século depois, quando as cinzas de Augusto também foram colocadas lá, os transeuntes tinham a chance de ler suas Res Gestae, inscritas em placas de bronze e afixadas em pilares externos a ele. (...) os transeuntes também podiam, de tempo em tempo, levantar seus olhos do texto e observar, de uma altura de 40 metros sobre a qual ele estava de pé, uma imagem de César Augusto que havia subido sobre a tumba. Retornando ao texto, ele era provavelmente não tão esperto para lê-lo como um documento republicano" (MILLAR, 1984, p.57-58).
\end{abstract}

\footnotetext{
${ }^{2}$ Suetônio nos aponta que Augusto, devido às realizações arquitetônicas empreendidas em seu principado, se vangloriava com a seguinte frase: "Deixei de mármore a Cidade de tijolos que recebi" (SUETÔNIO, Augusto, 28).
} 
No entanto, não é bem assim que as fontes escritas nos apresentam a ação política de Augusto. Ele teve com e contra quem agir até se tornar superior a todos em auctoritas. Uma superioridade que foi construída aos poucos (e que esteve constantemente sendo reafirmada durante seu principado) e que mesmo ao ser traduzida ao povo romano (aqui no termo mais geral incluindo senadores, soldados, plebeus, estrangeiros, provinciais, libertos e escravos) teve que seguir determinados preceitos que não entrassem em desacordo com toda a encenação ao seu redor. Como Zanker aponta, o meio escolhido por Augusto ao ornamentar a Urbs foi o de não fazer nenhuma referência direta aos rivais. No entanto, um dos principais referenciais utilizados pelo príncipe estava ligado a sua principal vitória militar e a que possibilitou, grosso modo, a implantação do Principado: a batalha do Actium (ZANKER, 1988, p.79-100).

A presente pesquisa tem como objetivo central entender a ação política de Otaviano/Augusto, empreendendo uma análise de toda a sua vida política, de sua ascensão após os Idos de março de 44 a.C. até sua morte em 14 d.C., visto a necessidade de seu principado só poder ser compreendido em conjunto com a sua ascensão política e a sua ação enquanto triúnviro. O que nos provoca a análise é ver como Augusto, ao implantar o sistema político do Principado romano, mesmo que durante seus 40 anos de ação como princeps senatus ainda não houvesse se consolidado como o centro da cena política, como vemos nos principados posteriores ao dele, agiu manipulando símbolos, discursos e estabelecendo um comportamento social que deveria ser, grosso modo, aquele que serviria de modelo aos governantes posteriores. E como tais atitudes foram tomadas tendo o outro (estrangeiro) como elemento presente na preservação do nós (romanos).

Destacamos três pontos no presente trabalho de pesquisa que nos nortearam e que procuraremos articular no intuito de trazer nosso olhar sobre Otaviano/Augusto. O primeiro deles é o discurso do príncipe de restauração da República, algo essencial para sua consolidação na cena política romana em uma fase tão conturbada de desarticulação da República. A historiografia já muito abordou este ponto, no entanto, cremos que podemos contribuir mais um pouco para o entendimento do porquê da escolha desta via como caminho de chegada e manutenção no poder. O segundo deles é a visão de certo perigo que representavam os contatos com o exterior e como esses contatos foram traduzidos para o contexto político romano. Algo importante nessa fase de crise civil romana e de contatos com outras realidades políticas, as quais poderiam provocar um não retorno à antiga República romana através da influência de determinados aristocratas que poderiam estar se corrompendo 
e visando um poder individual, causando talvez a instauração de uma monarquia ou tirania. $\mathrm{O}$ último é a noção de 'teatrocracia política', pois vemos a cena política como permeada por uma encenação em que discursos, construções de retratos, comportamento social, símbolos e interesses políticos estão intimamente ligados, ainda mais numa época conturbada politicamente e de consolidação da dominação romana em diversas regiões do Mediterrâneo.

Desse modo, nosso exercício reflexivo busca compreender com e contra quem Otaviano/Augusto atuou em sua 'restauração da República' e o que esse papel de restaurador significou para ele. Não nos preocuparemos apenas em ver como foi a ação de Augusto com os romanos. Entender a sua relação com os seus rivais, principalmente Marco Antônio e Cleópatra, é para nós um ponto central para o próprio entendimento de muitos dos caminhos escolhidos por Augusto em sua mise en scène. Esses três personagens devem ser visualizados como peças de um mesmo quebra-cabeça, o de transição da República para o Principado, e fruto de um mesmo movimento narrativo sobre o passado da Urbs, em que alguns receberam os louros e outros as críticas. Assim, tomamos para nossa análise a compreensão de como a construção de um retrato de Marco Antônio como um romano degenerado e a caracterização de Cleópatra enquanto uma rainha desejosa por dominar Roma permitiram a Otaviano/Augusto se colocar como um bom romano.

Durante o último século da República, houve uma maior difusão do temor de uma dominação da Urbs através da instauração de uma tirania ou monarquia, visto o crescimento da importância política, social e econômica que os generais aristocráticos estavam obtendo junto ao corpo civil romano. Somado a isso, devemos destacar a maior intensidade nas trocas culturais entre romanos e os estrangeiros devido à própria ação romana em grande parte do Mediterrâneo. Roma passou a estar em franco contato com elementos do exterior, seja nos reinos ou cidades estrangeiras, seja na própria $U r b s$, e esses estiveram intimamente ligados ao cenário político e alguns deles compuseram uma cartilha de críticas entre os aristocratas romanos nas disputas políticas existentes.

Cícero, por exemplo, ao mostrar as razões que tornavam os gregos ${ }^{3}$ inferiores aos romanos, nos aponta que os excessos, as formas dos banhos, os exercícios nos ginásios, as ações libidinosas, as reuniões noturnas (CÍCERO, Sobre a República, IV, 3), eram alguns desses pontos do comportamento social mal vistos e não permitidos a um bom romano, visto a ciuitas e o ócio produtivo, em prol do povo romano, estarem acima de tudo, de acordo com a prática discursiva moralizante de alguns membros da aristocracia romana. A esses pontos de

\footnotetext{
${ }^{3}$ Grosso modo, a matriz cultural compartilhada no Mediterrâneo era de origem grega, por isso da escolha dessa passagem de Cícero.
} 
críticas, podem ser acrescidos a adoção de práticas religiosas estrangeiras e de uma vida luxuriosa, por exemplo, aos romanos que 'fugiam' ao modelo dos costumes da Urbs, o mos maiorum. Esses elementos do exterior foram parte do discurso de temor da deturpação dos mores romanos, o que exigia um contra-discurso de restauração da República, que foi o que Otaviano/Augusto fez e o que o possibilitou se consolidar em Roma e implantar o Principado romano como nova forma de se jogar a cena política romana, numa fase de adaptação da Urbs a sua condição de caput mundi e detentora de um grande império territorial que se estendia por quase toda a bacia mediterrânica, mesmo que através de um discurso de que os costumes antigos que estavam sendo restaurados e que ele, Augusto, não possuía nada de excepcional em relação aos demais a não ser sua auctoritas (Res Gestae, VI, 34).

No entanto, quando observamos as primeiras críticas aos opositores de Otaviano/Augusto, não é apenas críticas a uma matriz grega que é tomada nos processos de criação de estereótipos de Marco Antônio e Cleópatra, mas sim elementos culturais dos povos que eram dominados pelas monarquias helenísticas e que não haviam sido absorvidos pela parcela política da aristocracia, como associações com deuses estrangeiros, por exemplo. As realidades orientais foram traduzidas para o interior do cenário político romano tendo como intuito demonstrar o perigo que a adoção de elementos delas pudesse causar uma maior desarticulação da própria estrutura republicana dos romanos. Ao agir politicamente, Augusto procurou reforçar seu pacto com a Urbs e com os romanos, respeitando os mores, o que reforçava a dominação aristocrática e o afastava de uma possível acusação de haver empreendido a absorção de padrões estrangeiros para atuar politicamente em Roma, não que não tenham ocorrido algumas apropriações de elementos exteriores, os quais já eram prática recorrente entre os republicanos.

Buscamos observar como se operou o processo de tradução do outro oriental na época augustana e compreender as intenções envolvidas nessa dinâmica interpretativa. As realidades orientais foram peças nesse cenário, mas podemos argumentar que existiu uma ameaça oriental a Roma? E se existiu, no que ela consistiu? Cleópatra pode ser vista como representante de um mundo completamente oposto ao romano e como alguém que visava dominar Roma? A historiografia aponta esse perigo oriental, apesar das considerações sempre vagas, mas ele deve ser inserido dentro da lógica teatral do poder em Roma. O Oriente era como um mosaico cultural e político, em que as estruturas dessas sociedades que viviam no Mediterrâneo oriental eram traduzidas, através de um prisma político-moral, para a sociedade romana. Existiram diferentes modos de se transmitir aos romanos os estrangeiros. Apenas 
determinadas características foram consideradas de modo negativo, de acordo com os próprios interesses de cada autor e de cada época.

Também devemos apontar que é preciso ter cautelas com a visão do outro oriental, mostrando que esse arcabouço é mais um fruto do nosso tempo do que da Antiguidade, pois os romanos não possuíam a visão que temos hoje dessa região geográfica, até por que eram outras as realidades sociais que existiam nesse período. Nosso olhar é muito permeado pela visão de mundo orientalista advinda, sobretudo, do século XIX, como Said (2007) bem expõe.

Não nos cabe aqui, afirmar se houve ou não uma ameaça estrangeira, termo que seria mais apropriado do que ameaça oriental, ao poder romano na Urbs. O que pretendemos é analisar como tal argumento foi construído e utilizado no interior de uma disputa pela primazia do poder numa fase política conturbada. Devemos inserir os personagens históricos, os nossos principais objetos de estudo, como bem aponta Bloch, em seu tempo (BLOCH, 2002, p.54-55), ou seja, no cenário político romano, nosso palco de ação por excelência. No entanto, não nos focaremos apenas em fazer uma apresentação biográfica desses personagens. Pelo contrário. Nosso objetivo é olhá-los através do prisma que permeia nossa pesquisa, vendo-os dentro de um discurso político romano no contexto da disputa pela 'restauração' da República. Pretendemos através do elencar de alguns pontos presentes nos retratos destas três figuras, legados a nós pelas fontes greco-romanas e pela numismática, por exemplo, mostrar como o mundo oriental foi uma peça importante no quebra-cabeça da luta do poder romano, mas no sentido de vê-lo como o pano de fundo para a caracterização de Marco Antônio e Cleópatra, de forma negativa, e de Augusto, de forma positiva.

O quadro de atuação de Augusto é muito mais complexo do que aquele que ele próprio apresenta em suas res gestae ou na estrutura material da Cidade. Tratar dos opositores foi delicado e precisou ser bem elaborado por Augusto, pois os partidários de Marco Antônio também eram homens que detinham cargos e influência dentro da estrutura da República. No entanto, ao ser realizado, se tornou num importante artifício para sua ação na cena política.

Cabe agora um breve panorama dos capítulos da dissertação. Nosso texto foi dividido em três blocos analíticos. Os títulos adotados para cada capítulo de nosso trabalho resumem, de certo modo, a temática que procuramos abordar em cada um deles no intuito de montar o quebra-cabeça da análise proposta.

No primeiro capítulo, 'Otaviano, Marco Antônio e a República' tomamos como tema a relação entre Otaviano e Marco Antônio. O recorte cronológico que analisamos é o do Triunvirato romano, o qual foi o pano de fundo de atuação dos dois em conjunto. 
Inicialmente, procuramos mostrar como o relacionamento entre eles se deu de modo incerto desde antes da ocupação pelos dois, juntamente de Lépido, do Triunvirato até o rompimento definitivo no momento de preparação para o confronto bélico entre eles em Actium. Foram anos em que diversos acordos e desacordos estiveram presentes e deram a tônica da relação. Num segundo momento, nos dedicamos a analisar a construção da depreciação da imagem de Marco Antônio, realizada no interior do período de posse da magistratura do Triunvirato, justificativa utilizada para o rompimento entre ele e Otaviano, por este último, devido ao seu desvio dos padrões de comportamento civil, tanto pela adoção de elementos estrangeiros, quanto pela preferência apresentada com relação à rainha Cleópatra, em detrimento da Urbs, como nos apontam as fontes. Este primeiro espaço de análise traz justamente como foi realizada uma apropriação da imagem de Marco Antônio no cenário político romano e como a depreciação dele foi utilizada no processo de implantação e legitimação do Principado de Augusto.

Nosso segundo capítulo, 'Augusto e a ameaça da realeza', tem como objeto a rainha Cleópatra e a busca por mostrar como a sua tradução, de modo nefasto, era importante para a justificativa, primeiro, da degeneração de Marco Antônio, segundo, de uma ação salvadora de Otaviano/Augusto diante de uma ameaça dela ao Capitólio romano. A monarquia durante os últimos séculos da República passou a ser mal-vista por parcelas da aristocracia romana ao denunciarem que seus inimigos apresentavam comportamentos que saíam de um padrão moral, o mos maiorum, um importante pilar da dominação aristocrática. Esses romanos degenerados poderiam se constituir em opositores à República, já que não seguiam determinados modos de agir dos antepassados, o que fazia com que os denunciantes se colocassem como aqueles que defendiam de fato a ciuitas romana. Esse jogo de se (des)construir os rivais era muito importante e foi apropriado por Otaviano/Augusto. Não devemos nos esquecer que a guerra vencida em Actium foi declarada à Cleópatra, apesar de ser Marco Antônio o alvo do confronto, e que para que fosse possível esta batalha seria necessário ter ocorrido, de antemão, a construção e difusão de um discurso de legitimação da ação do defensor da República, o qual era baseado na desconstrução da rainha.

O último capítulo da pesquisa, ' $O$ comportamento social de Augusto', procura justamente entender como foi a mise en scène de Otaviano/Augusto, como ele atuou no cenário político romano. Não nos focamos apenas em seu principado, mas este, por ser o momento em que ele esteve numa posição de destaque político, acaba por ser nosso principal período. Observamos como Otaviano/Augusto agiu na teatrocracia política e soube construir, legitimar e manter sua posição proeminente perante os demais homens da República. Assim, 
tomamos suas relações com outros setores sociais, seus cargos, suas honras e seus símbolos de poder numa fase tão importante da história romana, em que a República passava por mais uma adaptação. Como prisma analítico, utilizamos também o mundo oriental e buscamos apontar como ele foi um elemento que esteve presente não só para a (des)construção dos retratos de seus rivais, mas também como um importante arcabouço em sua própria forma de ação política, mesmo que, em muitos casos, através da negação de alguns referenciais. $O$ viés utilizado por Augusto foi o da valorização dos costumes romanos, mas alguns dos elementos utilizados foram conscientes num intuito de não relembrar um ideal monárquico, modelo de governo contra o qual ele combatera. 


\title{
OTAVIANO, MARCO ANTÔNIO E A REPÚBLICA
}

\begin{abstract}
"Finalmente [Otaviano] rompeu a aliança sempre dúbia e incerta com M. Antonio, mal restabelecida por várias reconciliações, e, para que pudesse melhor provar que ele tinha degenerado dos padrões de comportamento civil, fez abrir e ler em público o testamento que ele deixara em Roma e que também nomeava os filhos de Cleópatra como seus herdeiros. Contudo, depois que ele foi julgado inimigo público, enviou-lhe todos os seus parentes e amigos" (SUETÔNIO, Augusto, 17).
\end{abstract}

O pequeno excerto acima da biografia de Augusto, escrita por Suetônio, expõe uma visão de como estava estruturada a relação entre Otaviano e Marco Antônio. O biógrafo romano aponta que a aliança entre esses dois homens era dúbia, incerta, repleta de reconciliações e que ela foi rompida por Otaviano devido a ações inadequadas de Marco Antônio para com os costumes romanos. Os dois enquanto triúnviros, o que foram por 10 anos, deveriam zelar pelo bem da República e buscar amenizar os problemas civis pelos quais os romanos estavam passando, principalmente no que diz respeito à disputa política, que durava quase um século.

Durante o Triunvirato os dois atuaram na cena política romana não apenas em Roma, mas no Mediterrâneo, estando em contato com diversos setores sociais da Urbs e com diversos governantes de outros povos, sendo eles as referências de Roma na época. Portanto, analisar a relação entre os dois é importante para entendermos o equilíbrio de forças desse período tão importante para a história romana e para a República romana.

Os relatos do passado nos apresentam que essa relação se deu de modo tumultuado e ambíguo, com diversas reconciliações entre eles até a ruptura final. No entanto, devemos observar Otaviano e Marco Antônio como frutos de um mesmo movimento, de uma manipulação dos símbolos e da criação de discursos na ação teatral da disputa política. Os dois ocuparam um espaço de grande importância no cenário romano no período posterior à morte de César e as ações desses dois homens são importantes para entendermos a própria forma como o Principado foi estabelecido. 
Nosso exercício reflexivo no presente capítulo se inicia com uma exposição do que foi o Triunvirato e como esses homens são vistos por alguns autores romanos antigos enquanto ocupantes de tal magistratura. Devemos saber suas origens e como as tramas da ação política foram ocorrendo nesse período, pois foi, grosso modo, no intervalo desses 10 anos, que ligam a morte de César ao estabelecimento do confronto direto entre Otaviano e Marco Antônio, que permitiu o surgimento mais sólido das bases da auctoritas do futuro Augusto.

O excerto de Suetônio nos será a mola reflexiva principal na divisão empreendida para se analisar a relação entre Otaviano e Marco Antônio. Através de suas palavras, temos dois eixos temáticos possíveis de análise: a relação incerta entre os triúnviros e as acusações de degeneração dos comportamentos civis de Marco Antônio por Otaviano. Esses dois blocos analíticos serão desenvolvidos no decorrer de nosso texto no intuito de mostrar como a encenação política se deu nesse período, como algumas regras eram importantes para a mise en scène e como elas foram utilizadas nessa disputa política.

Nosso principal objeto é visualizar como a construção de uma imagem negativa de Marco Antônio era essencial para que Otaviano se estabelecesse na cena republicana. O mecanismo utilizado foi o de oposição entre o eu e o outro, enquanto o primeiro, no caso Otaviano, se mostrava superior ao outro, Marco Antônio, trazido como inferior, principalmente devido às suas ações no mundo oriental. Não ocorreu apenas um processo de construção da auto-imagem enquanto um homem que agia em prol da República romana. Para Otaviano era necessário diminuir o rival, pois o que existia era um jogo em busca da maior auctoritas, importante na cena política.

$* * *$

Nosso trabalho se inicia em 44 a.C., com os episódios que se sucederam após os Idos de março. Temos um cenário conturbado na Urbs: o principal homem da República romana de então, Julio César, que ocupava o cargo de dictator perpetuus, estava morto após ter sido assassinado por uma conspiração senatorial em uma sessão do Senado junto à estátua de Pompeu. Como Cosme apresenta o período, entre os senadores tal acontecimento não teve, inicialmente, uma repercussão tão violenta, devido aos acordos pacíficos realizados entre os pares, no entanto, no funeral de César, houve uma ação mais calorosa por parte da plebe e dos veteranos do antigo general, o que foi agravado com a posterior leitura de seu testamento, pelo qual, ambos os setores, plebeus e soldados, haviam sido agraciados com uma quantia per capita pelo falecido ditador. Alguns senadores acabaram fugindo de Roma em decorrência de 
um temor de ataques das camadas mais populares. É nesse ínterim que de Otaviano ${ }^{4}$, filho de Átia, sobrinho neto de Júlio César, que se encontrava em Apolônia aprimorando seus estudos e que então contava com 18 anos, se dirigiu à $U r b s$ em busca de seus direitos junto ao espólio do antigo ditador. Entretanto, muitos membros da elite senatorial também haviam permanecido em Roma, sobretudo aqueles ligados a Julio César e aos populares, como, por exemplo, Marco Antônio e Lépido, que junto com o jovem herdeiro do antigo ditador serão muito importantes para a cena política dos anos posteriores. (COSME, 2005, p.20-36).

A escolha do momento posterior à morte de César como marco cronológico inicial de nosso recorte se faz por entendermos que os eventos que sucederam ao assassinato do ditador são de grande importância para a compreensão de como e por que se estabeleceu o acordo conhecido como Segundo Triunvirato. Nada na História acontece ao acaso, há sempre uma razão, pois os eventos estão todos encadeados de alguma forma, mesmo que não consigamos visualizar por completo os motivos que levaram a determinado fato histórico ${ }^{5}$.

O Triunvirato foi um momento crucial para a República romana. No entanto, a encenação do equilíbrio de forças do poder romano se iniciou antes do estabelecimento do acordo, depois ratificado pela Lex Titia, entre os triúnviros em novembro de 43 a.C.. Com a chegada de Otaviano em Roma e a sua transição entre os senadores e Marco Antônio através de laços políticos, já temos um primeiro exemplo de sua mise en scène. O relato de Dion Cássio $^{6}$, apesar de ser muito posterior aos acontecimentos, e por isso, pouco utilizado pelos historiadores, mas que, a nosso ver, não merece total descrédito, nos mostra bem como esse início, assim como todo o período de 10 anos do Triunvirato e os anos seguintes de preparação e de guerra em si (que ocorre em Actium, em 31 a.C.) são marcados por uma constante instabilidade nas relações políticas, sendo acordos feitos, refeitos e desfeitos.

Para Millar, o Triunvirato foi uma fase de violência, ilegalidade e arbitrariedade no exercício do poder, em que os triúnviros usurparam os poderes da República. No entanto, o autor argumenta que mesmo assim, as estruturas básicas do funcionamento dos negócios públicos continuaram existindo e sendo os meios de ação desses homens, o que também é

\footnotetext{
${ }^{4}$ Mais uma ressalva quanto a denominação de nosso personagem se faz necessário aqui. O nome Otaviano pelo qual o denominamos neste capítulo, para o presente é anacrônico. O nome Otaviano só foi adotado após a efetivação da adoção por Julio César, de acordo com as regras jurídicas romanas, em 42 a.C.. Nos eventos pós Idos de março ele ainda se nomeava Otávio Turino. Para maiores detalhes de como os autores antigos abordam a questão, Cf: SUETÔNIO, Augusto, 7; DION CÁSSIO, História Romana, XLVI, 47.

5 Pelling, por exemplo, começa sua análise sobre o período triunviral a partir do estabelecimento do próprio acordo, sem abordar nada com relação a César, apenas apontando sobre a sua divinização (PELLING, 2001, p.1). No entanto, a grande maioria dos autores começa em 44 a.C. seus textos.

${ }^{6} \mathrm{Na}$ obra de Dion Cássio denominada de 'História Romana', os eventos pós-Idos de março, Triunvirato e fase de Actium são narrados pelos livros 44 a 51, os quais nos chegaram de forma integral.
} 
visto na época imperial. Ou seja, o Triunvirato foi um período importante para as mudanças do sistema político. Digamos que tenha sido como uma fase em que os romanos passaram a se acostumar com o poder nas mãos de cada vez menos pessoas, o que em muito ajudou para o estabelecimento do Principado (MILLAR, 1973, p.50-67).

Conforme Scheid, essa foi uma época de gestação das características institucionais da figura do princeps (SCHEID, 1990, p.8). Alföldy, em sua análise sobre a sociedade romana, aponta que nessa fase de mudanças (a de expansão da República de um modo mais amplo, não apenas o Triunvirato, sendo esse apenas a parte final de todo um processo), o que mudou de fato foi a estrutura de poder na qual a sociedade romana se apoiava (ALFÖLDY, 1989, p.81-83), o que nos mostra como não houve nenhuma grande ruptura social com a República.

Pelling também apresenta uma visão negativa do Triunvirato. Segundo o autor, "Em 27 de novembro de 43 a.C., a Lex Titia iniciou o período de governo absoluto em Roma”. Ele argumenta que apesar dos triúnviros serem responsáveis pela restauração da República, esta, de fato, se encontrava morta, pois os três detinham superpoderes. Eles poderiam aprovar ou anular leis sem consultar o Senado ou o povo, exercer a jurisdição sem nenhum direito de apelo, escolher os magistrados e ainda haviam dividido as terras romanas entre eles. E aponta que o mundo romano estava em mudança (PELLING, 2001, p.1).

Esta foi uma fase de encenação importante, sobretudo para Otaviano, pois nesses 10 anos de Triunvirato ele conseguiu se estabelecer na cena política romana e ser considerado o defensor da República contra um romano degenerado dominado por uma rainha estrangeira, de acordo com seu discurso. O Triunvirato deve ser observado sob esse prisma de um período de negações, de conquistas, criação de visões de mundo, de estabelecimento de algo novo no seio dos poderes republicanos.

Desse modo, é nesse contexto que devemos visualizar a disputa entre Otaviano e Marco Antônio, principalmente após o isolamento de Lépido realizado pelo primeiro, em 36 a.C.. Também deve ser acrescido a tal processo o papel que foi exercido por Cleópatra. Mais do que outrora, a relação entre a coroa egípcia e os magistrados romanos se estreitava. Como nunca antes visto, as decisões tomadas em Alexandria ou em Roma, se viam como decisivas para o outro lado, pois de uma linha de reis clientes dos romanos, Cleópatra se mostrou como um importante aliada de Marco Antônio, ao ponto de ser considerada inimiga dos romanos. Assim, de vários caminhos a serem seguidos, uma proposta de que todos estariam livres com o retorno da libertas e a restauração da República foi instaurada e adotada pelos romanos: o Principado. Uma alternativa que foi construída e continuou sendo perpetuada com o passar dos anos através de constantes processos de legitimação. 
Como argumenta Silva, a fase do Triunvirato foi uma fase de incertezas, sem que Otaviano pudesse construir um projeto de si mesmo que simbolizasse o título que ele recebeu anos depois de Augustus, ou seja, ele não tinha a projeção de se constituir na figura que o título simboliza (SILVA, 2014, p.61). Ora, como as fontes nos apresentam, os anos de Triunvirato foram permeados por um conjunto de relações múltiplas e dúbias entre os triúnviros e outros romanos, tanto aristocratas quanto senadores.

A vida política de Otaviano/Augusto foi marcada por um conjunto de experimentações, que a cada novo episódio tinham que ser executadas ou elaboradas. Eder nos aponta que o Principado não foi oferecido 'ao Senado e ao povo romano' numa espécie de cartilha fechada (EDER, 2005, p.16-17) e isso diz muito a respeito da própria situação delicada de Otaviano, como continuou sendo até sua morte. O Triunvirato é um momento ímpar para que possamos entender o estabelecimento do Principado, pois foi no seu interior que todos os discursos e retratos foram gerados, mesmo que em alguns casos de forma embrionária para serem mais bem desenvolvidos em oportunidades posteriores. E sua relação com Marco Antônio se insere nesse contexto conturbado em que todo um aparato simbólico precisava ser construído.

O que significava ser triúnviro e quais as obrigações de tal magistratura?

O título adotado pelos três foi triumviri rei publica constituendae, triúnviro para que a República se reconstitua, ou seja, os três homens responsáveis pela restituição da constituição da República. Assim sendo, o primeiro ponto que merece atenção é o compromisso para com Roma. Ora, ambos eram cidadãos romanos investidos de magistraturas romanas e membros da elite senatorial. Deveriam se dedicar ao restabelecimento do sistema republicano, algo reforçado pela própria função de triúnviro, e engrandecer Roma. Contudo, não é propriamente isso que os relatos antigos nos trazem a respeito dos dois principais triúnviros. A nosso ver, este é o principal ponto que distingue os retratos dos dois romanos. As principais críticas a Marco Antônio pelos escritores antigos se inserem dentro dessa ótica, a de que ele era um romano degenerado e, em oposição, Augusto é retratado, exceto mais claramente por Tácito (Anais, I, 10), como um romano modelo e compromissado com a República ${ }^{7}$, com um discurso político de defesa da República, como podemos observar através de algumas passagens de suas res gestae.

\footnotetext{
${ }^{7}$ Reinhold e Swan nos apontam a ambiguidade com a qual Otaviano é trazido por Dion Cássio na sua 'História Romana': enquanto triúnviro, Otaviano era visto negativamente, no entanto, como príncipe, Augusto passa a ser visto positivamente, pois permitiu aos senadores voltarem ao jogo político (REINHOLD; SWAN, 1993, p.159).
} 
O acordo inicial de Bononia, ratificado pela Lex Titia, previa um comando de cinco anos dos três homens para, segundo Dion Cássio, "administrar e organizar a República [...] com o direito de governar sem comunicar o povo e o Senado e dar magistraturas, assim como outras honras, a quem eles quisessem", além de ter havido uma divisão das terras romanas, cabendo a Otaviano a Líbia, a Sardenha e a Sicilia; a Lépido a Espanha e Gália Narbonesa e a Marco Antônio o restante da Gália, tanto a Cisalpina quanto a Transalpina (DION CÁSSIO, História Romana XLVI, 55). Logo após disso eles começaram a se preparar para a guerra contra os cesaricidas e iniciaram também o processo de proscrições.

Logo no início das res gestae, Augusto trata do Triunvirato, dizendo que foi triúnviro e quais as prerrogativas de tal cargo: "Fez-me [o povo] também triúnviro com a incumbência de que a república houvesse de se consolidar" (Res Gestae, I, 1). No entanto, a cena política não foi tão cheia de honras como ele aponta nesse primeiro parágrafo de suas res gestae. Houve muita negociação e arbitrariedade. O importante é Augusto ressaltar que era em prol da República que ele agia enquanto triúnviro, um ponto importante para reforçar sua vida política e mostrá-lo em oposição a muitos que poderiam não querer o bem da República.

Contudo, são poucos os documentos antigos que tratam a respeito do que foi o Triunvirato. Millar se preocupa em entender quais os poderes e a relação dos triúnviros com as estruturas republicanas e aponta que as fontes falam pouco a respeito dos poderes, sendo Apiano e Dion Cássio, autores tardios, a tratarem da questão, o que não se observa nas fontes contemporâneas aos fatos. No que concerne às magistraturas e às assembléias, como já visto, elas continuaram existindo e sendo o meio de ação desses homens, apesar de algumas atribuições extras que eles possuíam (MILLAR, 1973, p.50-54). Essa pouca importância dada pelos autores da Antiguidade a uma apresentação sistemática do que viria a ser o Triunvirato diz muito do próprio objetivo delas e também pelo fato de talvez ser senso comum sobre o que se tratava ser a referida magistratura. As questões que pomos a elas hoje são diferentes daquelas que elas se propunham a responder quando foram concebidas ${ }^{8}$, o que em parte dificulta o métier do historiador.

Exemplos disso, apesar de posteriores, são as duas biografias que possuímos sobre Marco Antônio e Augusto, que também não se dedicaram a uma apresentação sistemática do

\footnotetext{
${ }^{8}$ Os antigos possuíam uma visão da História como objeto de ensino e de transmissão de um passado glorioso, o que não pressupunha um rigor com o uso das fontes e a transmissão da informação como possuímos atualmente. Apesar de muitos autores recorrerem a referências a outras pessoas do passado ou autores, o tom moralizante dos escritos que importava mais. Para eles, a história era a magistra vitae, ou seja, um lugar de onde se tiravam os exemplos a serem seguidos ou não (CIZEK, 1995, p.9-11). Como Koselleck aponta, apenas no século XIX que a História deixa de ser vista unicamente como um compêndio moralizante, o que ocorreu por mais de dois mil anos, e passa a ter um estatuto mais científico e com isso, mais rigoroso quanto às referências e personagens (KOSELLECK, 2011, p.41-47).
} 
Triunvirato ou das ações dos triúnviros. O texto de Plutarco sobre a vida de Marco Antônio, contido nas 'Vidas Paralelas', não tem como foco narrar as ações do personagem principal enquanto triúnviro. A preocupação do autor é muito mais fazer uma apresentação do retrato moral de Marco Antônio. Para ele, esta foi uma época negativa para os romanos, sendo as críticas ao comportamento de Marco Antônio o que de pior podia existir (PLUTARCO, Marco Antônio, 21). Apesar disso, ele nos fornece elementos da ação de Marco Antônio enquanto triúnviro, narrando as relações dele com os reis e com as cidades orientais. Mostranos suas preparações para as guerras, principalmente a guerra contra os partos, e como ele estabeleceu sua ligação com aquelas sociedades. Plutarco também nos mostra algumas etapas dos novos acordos do Triunvirato ao narrar as relações entre os triúnviros, como a paz de Brindes, em 40 a.C., e o acordo de Miseno com Sexto Pompeu, em 39 a.C. (PLUTARCO, Marco Antônio, 30-32; 35).

Com relação a Suetônio, sua biografia de Augusto, contida em 'As vidas dos doze Césares', também não se dedica a narrar maiores detalhes da época do Triunvirato. A própria estrutura temática da biografia de Suetônio, diferente da de Plutarco, que é baseada no decorrer cronológico, impõe certos limites à narrativa dos eventos do Triunvirato, tocando em muitos aspectos daquela época, mas sem de fato construir uma narrativa sobre seus eventos. $\mathrm{O}$ que temos de mais específico é a apresentação de que Augusto foi triúnviro quando da explicitação do cursus honorum do biografado e também na descrição das guerras empreendidas por ele (Módena, as três enquanto triúnviro - Filipos, Perúsia e contra Sexto Pompeu - e Actium) (SUETÔNIO, Augusto, 8-18; 27).

Tomemos agora o trecho acima citado de Suetônio (Augusto, 17) que abre o presente capítulo como mola propulsora para nossa análise sobre o Triunvirato e a relação entre Otaviano e Marco Antônio 9 . De acordo com o biógrafo romano, a relação entre esses dois homens era instável e sempre necessitava ser reafirmada a cada problema entre eles; e que foi o testamento de Marco Antônio o motivo do rompimento final, devido às disposições lá contidas, o que afirmava seu corrompimento dos padrões civis. Dessa forma, temos duas linhas de pensamento a desenvolver a partir do fragmento de Suetônio. O primeiro dos pontos que merece atenção é o equilíbrio de forças entre os triúnviros, a forma como o acordo entre eles se estabeleceu e foi sendo restabelecido através de reconciliações até o rompimento final. O segundo ponto diz respeito ao desvio dos padrões civis, o não cumprimento do mos

\footnotetext{
${ }^{9}$ Para uma apresentação mais cronológica dos acontecimentos da época de Augusto, tanto do Triunvirato, quanto do Principado, Cf: COSME, 2005; CROOK, 2001a, p.70-112; CROOK, 2001b, p.113-146; PELLING, 2001, p.1-69. Ou utilizar nossa breve linha cronológica ao final do trabalho, Cf Anexo 1.
} 
maiorum e uma quebra de compromisso de Marco Antônio para com a República. E, aqui, temos um grande elemento de análise, sendo nosso objeto de estudo as ações de Marco Antônio e discursos de Otaviano com relação ao mundo oriental.

\section{Relação incerta}

O acordo do Triunvirato foi estabelecido em um momento muito conturbado, após os eventos de Módena, confronto entre Marco Antônio e Otaviano, em 43 a.C.. Apesar de sua ação virtuosa em prol da República, Otaviano se sentiu insatisfeito após as disposições senatoriais que concederam diversas honras aos cesaricidas, enquanto ele não obteve o reconhecimento que pretendia. Por isso, ele acabou se aliando ao seu antigo rival, juntamente com Lépido, e estabeleceram um acordo entre eles, o acordo do Triunvirato.

Como observado, os três se uniram após serem rivais em uma batalha militar e por se sentirem insatisfeitos com as disposições senatoriais, seja por causa da recusa da posse da Gália, no caso de Marco Antônio, seja devido ao não recebimento das honras desejadas, no caso de Otaviano. Claro que os rancores dos tempos pré-Triunvirato continuaram existindo durante o período em que os três agiram conjuntamente na cena política romana, sendo agravados com o passar dos anos ao calor dos eventos que se seguiram.

Foram 10 anos em que muitas batalhas aconteceram, muitas desconfianças surgiram e muitos laços foram estabelecidos entre eles no intuito de o pacto inicial, de duração inicial por 5 anos e que teve uma renovação em 37 a.C., não fosse rompido de forma inapropriada. No entanto, ao fim do período triunviral, o que ocorreu foi justamente um confronto bélico entre Marco Antônio e Otaviano, a batalha de Actium, em 31 a.C., após Lépido ser excluído do acordo em 36 a.C..

Inicialmente, o que observamos é que, no período de estabelecimento do pacto, os três homens procuraram se associar como três pessoas capazes de reorganizar a República, uma das prerrogativas da magistratura, mostrando que havia harmonia entre eles, o que reforçava a credibilidade do acordo. Um espaço que serviu como instrumento para esse intuito foram as moedas. Esses pequenos espaços da cultura material, importantes para a transmissão de mensagens, idéias e ideais passaram a ser amplamente utilizados entre os poderosos romanos no século I a.C., quando, principalmente, do início de uma atribuição mais pessoal do poder a determinados magistrados, o que também foi feito pelos triúnviros na exposição da relação entre eles. 
A imagem a seguir (Imagem 1) é um dos poucos exemplos que temos de uma peça monetária cunhada pelos três triúnviros conjuntamente. Apesar da temática do reverso tratar da deusa Artemis, o que nos importa é a representação dos três romanos no anverso. Neste exemplar podemos visualizar como os três procuraram ser associar um ao outro. A apresentação dos três mostra um equilíbrio entre eles, visto suas efígies estarem em igualdade de tamanho na representação, o que era essencial para dar uma visão legitimadora da nova posição política deles junto ao corpo civil romano.
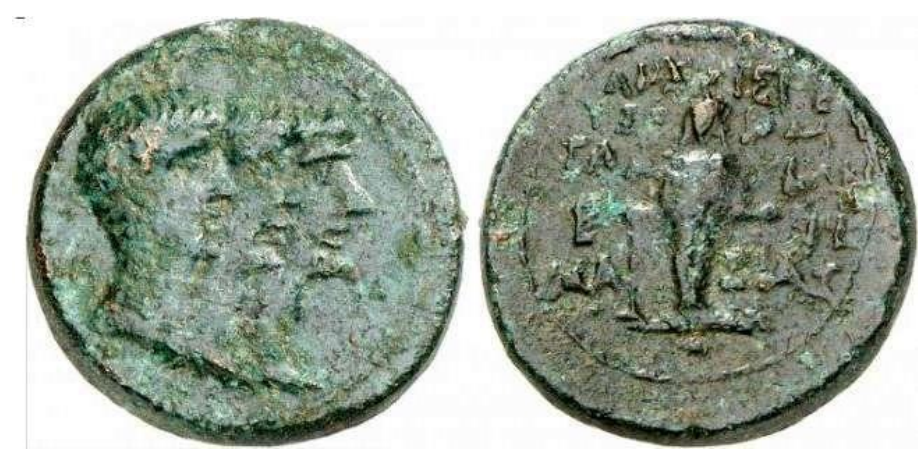

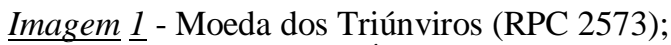

- denário (Éfeso);

- cunhada em 43 a.C.;

- Anverso: bustos dos triúnviros Otaviano, Marco Antônio e Lépido;

- Reverso: estátua do culto da deusa Artemis Efésia;

No entanto, a associação entre os triúnviros não se deu de uma única forma tentando mostrar o equilíbrio e a igualdade entre eles. Como exemplo disso, temos a peça numismática abaixo (Imagem 2). Nela observamos a representação de Marco Antônio e Otaviano como triúnviros como é explicitado pelas legendas junto ao busto de cada um (III VIR R P C triumviri rei publica constituendae). Contudo, o retrato de Otaviano é menor que o de Marco Antônio, o que mostra o intuito de representar o segundo como inferior, possivelmente em auctoritas e também pela pouca idade, Otaviano contava com 21 anos na época da cunhagem, o que é claro de se visualizar pelo seu retrato muito mais jovem ao do primeiro. Com isso, podemos perceber como havia uma construção de imagens e uma disputa também simbólica entre eles, sendo um utilizado como oposição para a auto-imagem do outro. O mais interessante é ver uma cunhagem de Marco Antônio, o que nos mostra como ele também se apropriou de um processo discursivo de construção de sua imagem sobre a dos seus aliados ou rivais, não somente através da prática oral. 

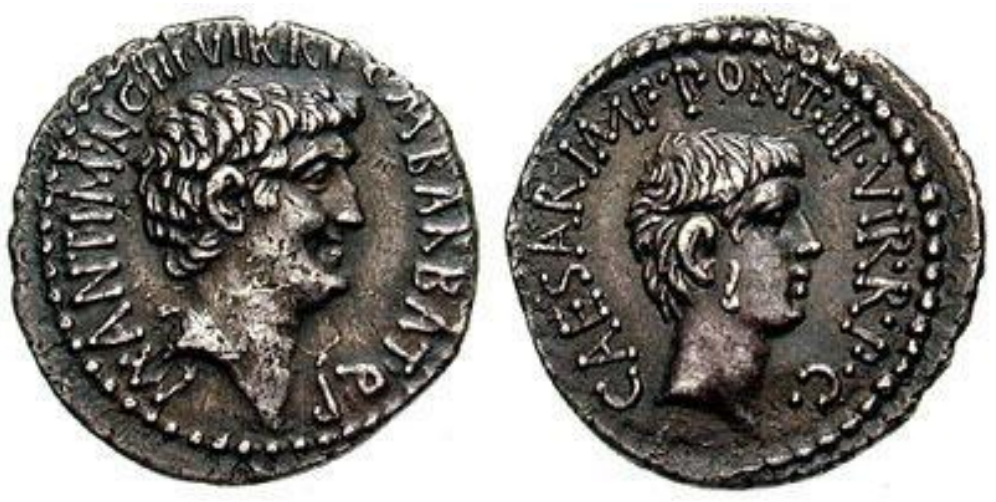

$\underline{\text { Imagem }} \underline{2}$ - Moeda dos Triúnviros Marco Antônio e Otaviano (RSC 8); - denário (Éfeso); - cunhada em 41 a.C.;

- Anverso: M ANT IMP AVG III VIR R P C M BARBAT Q P - bustos de Marco Antônio; - Reverso: CAESAR IMP PONT III VIR R P C - busto de Otaviano;

Esta peça é um exemplo de que as relações entre os triúnviros não era tão pacífica e equilibrada quanto se pretendeu mostrar na época do estabelecimento do acordo. $\mathrm{O}$ Triunvirato foi, na verdade, um período ambíguo e complexo, em que diversos outros personagens estiveram envolvidos na atuação política. As tramas estabelecidas entre os três triúnviros e outras pessoas que tinham participação na estrutura política da República fizeram com que as relações entre os três fossem sempre abaladas e reconstruídas.

Um exemplo do clima de instabilidade e de tensão que existia no mundo romano nessa época pode ser simbolizado pelo processo de proscrição instaurado no seio da elite romana logo após o estabelecimento do Triunvirato. Como Dion Cássio nos aponta, foi uma época cruel em que havia duas listas de proscritos, sendo difícil para os aristocratas romanos saberem a quem apoiar, pois se associar a um dos triúnviros significava deixar de ser partidário dos outros dois e, com isso, acabar caindo no desagrado deles e sendo inscrito em uma das listas (DION CÁSSIO, História Romana, XLVII, 3-14).

Desse modo, já observamos que uma magistratura que era para se basear no equilíbrio de forças se tornou numa disputa entre eles, o que foi agravado pelo desenrolar de eventos subsequentes. O primeiro deles foi a reorganização do cenário político após a batalha de Filipos, em 42 a.C., em que os cesaricidas foram vencidos. Com os antigos assassinos de César mortos, os poucos que sobraram passaram a apoiar Sexto Pompeu, tornando a cena política romana mais favorável para os triúnviros. Quando Marco Antônio e Otaviano venceram a guerra, as províncias orientais, que estavam sob domínio de Bruto e Cássio, entraram no bojo de terras romanas que poderiam ser partilhadas entre os triúnviros. Inicialmente Marco Antônio ficou com a Gália e as províncias orientais, enquanto Otaviano 
com a Hispânia e a tarefa de assentar os veteranos, sendo que Lépido apenas ganhou posteriormente a província da África.

O episódio seguinte foi o cerco a Perúsia, em 41 a.C., em decorrência de uma agitação social provocada por Fúlvia e Lúcio Antônio, respectivamente esposa e irmão de Marco Antônio. Este triúnviro se encontrava no Oriente cuidando de reorganizar politicamente a região e restabelecer os laços de dominação romana, bem como angariando fundos para uma futura guerra contra os partos. Marco Antônio nada teve com o cerco de Perúsia, apenas sua esposa e seu irmão que decidiram se opor a Otaviano, tomando à frente dos descontentes, tanto com os assentamentos dos veteranos, quanto com a carestia imposta por Sexto Pompeu. A vitória se deu por Otaviano e a relação entre os triúnviros, apesar da não participação de Marco Antônio, foi abalada.

Em decorrência disso, houve o estabelecimento de um acordo de reconciliação entre os dois, conhecido como a paz de Brindes, efetuado em 40 a.C., após os tumultos provocados pela batalha de Perúsia, no ano anterior. Este é um momento importante na relação dos dois. Como meio de selar o compromisso de amizade entre eles foi estabelecido o novo casamento de Marco Antônio, que se deu com a irmã de Otaviano, Otávia, e, assim, unia os dois pelo laço matrimonial e familiar. A peça monetária abaixo (Imagem 3) é um dos elementos difundidos pelos triúnviros, o de equilíbrio entre eles, o que é bem representado pelo caduceu do reverso, que é justamente um objeto que simboliza esse intuito.
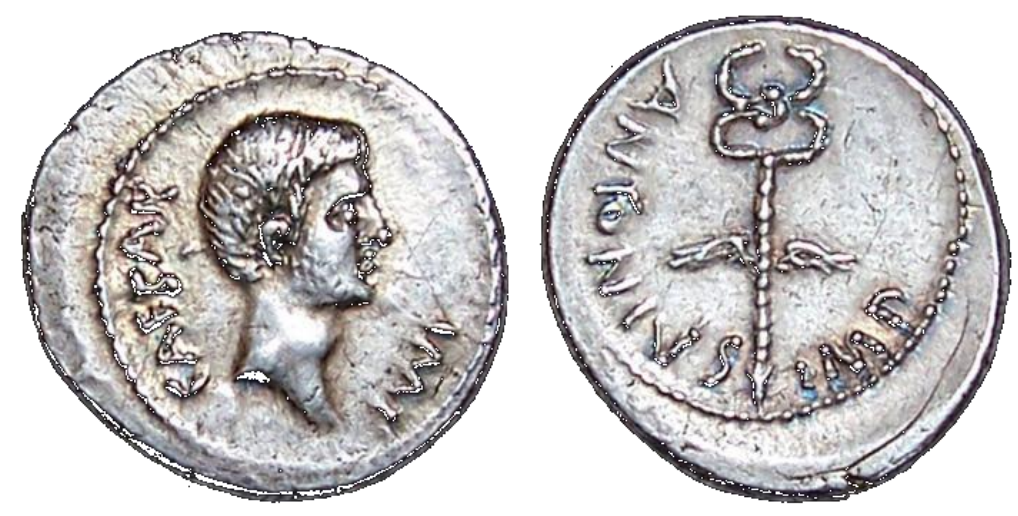

Imagem $\underline{3}$ - Moeda dos Triúnviros Marco Antônio e Otaviano (Crawford 529/2c); - denário (provavelmente Gália); - cunhada em 40-39 a.C.;

- Anverso: CAESAR IMP - busto de Otaviano com a cabeça nua; - Reverso: ANTONIVS IMP - caduceu alado; 
Em 39 a.C., um acordo foi estabelecido com Sexto Pompeu, o qual foi um personagem que causou grandes instabilidades nas relações políticas do período, em que ele passava a ter posse das províncias da Sicília e da Sardenha, bem como havia sido nomeado para um consulado futuro, o acordo de Miseno. Aparentemente, nesse momento, as relações políticas estavam mais harmoniosas, o que permitiu com que o Triunvirato fosse renovado por mais cinco anos a partir de 37 a.C..

Tomemos a biografia de Suetônio para análise. No interior da descrição da vida de Augusto, não há nenhuma referência direta a personalidade de Marco Antônio, sendo ele apenas um apêndice na construção do retrato de Augusto, ou seja, não há uma apropriação de possíveis desvios de conduta de Marco Antônio com o objetivo de narrar ações virtuosas de Otaviano/Augusto. No entanto, a forma como Marco Antônio é citado na biografia é interessante. O biógrafo latino se utiliza do personagem de Marco Antônio para trazer algumas críticas a possíveis desvios de conduta do príncipe e para isso traz algumas cartas ou acusações que Marco Antônio teria proferido contra Otaviano.

Quanto ao comportamento civil de Otaviano, temos Marco Antônio fazendo críticas a sua postura diante das batalhas e assim cita dois episódios, a sua fuga durante as batalhas de Filipos, em 42 a.C., e sua crise de sono durante as batalhas na Sicilia, em 36 a.C., contra Sexto Pompeu (SUETÔNIO, Augusto, 10; 16). Marco Antônio, com isso, acaba por tentar arranhar a imagem do então aliado de magistratura, procurando mostrar que ele não possuía habilidades militares, algo muito estimado entre os romanos.

Outro evento que foi criticado não somente por Marco Antônio, mas também por autores anônimos, de acordo com o biógrafo, foi a chamada 'festa dos doze deuses', um banquete no qual os convidados deveriam ser fantasiar de deuses. Otaviano fora travestido de Apolo. No entanto, Roma passava por uma grave época de carestia devido aos embargos feitos por Sexto Pompeu, tanto que Otaviano recebeu o apelido de Apolo torturador em consequência desse festim (SUETÔNIO, Augusto, 70). Suetônio, porém, argumenta que as ações de Otaviano no Egito, ao recusar qualquer objeto luxuoso da corte alexandrina, se mostra virtuoso e contrário as acusações de gostos exagerados por obras de arte e jogos (SUETÔNIO, Augusto, 71).

Contudo, o principal ponto de críticas de Marco Antônio se refere aos adultérios de Otaviano. Como Suetônio nos apresenta, os amigos de Otaviano não negavam esses deslizes de conduta e diziam que eram mais por cálculo político do que propriamente por luxúria. Já Marco Antônio focou em criticar a forma como Augusto procedeu com Livia em meio a um jantar ao levá-la para o quarto enquanto seu marido se encontrava junto aos convidados e ao 
apontar que Escribônia, primeira esposa de Otaviano, havia sido repudiada após reclamações de que uma das amantes de seu esposo detinha muito poder (SUETÔNIO, Augusto, 69).

Entretanto, dentro desse quadro de acusações de ações adúlteras de Otaviano, temos uma carta de Marco Antônio que Suetônio transcreveu e que nos é muito significativa, isso antes de terem se tornado inimigos: “O que mudou? É porque me deito com uma rainha? Ela é minha esposa. Comecei a fazê-lo agora ou há nove anos?” e continua, “Tu te deitas apenas com Drusila? Passar bem, se, ao leres esta carta, não tiveres dormido com Tertula, Terentila, Rufila, Salvila, Tisticênia ou com todas elas! Acaso importa quando ou diante de qual tens uma ereção?” (SUETÔNIO, Augusto, 69). Aqui fica transcrita uma clara acusação de adultério por Otaviano. Quanto a Marco Antônio, ele já havia repudiado Otávia. Mas, mais do que isso, temos aqui, como será analisado posteriormente, um elemento das críticas de Otaviano a Marco Antônio, o relacionamento deste com a rainha egípcia, e como se isso que de fato fosse inaceitável.

Um último bloco temático se refere às críticas à baixa ascendência de Augusto, pois Marco Antônio se dirigia a Augusto como Turino, o qual era seu cognomen (SUETÔNIO, Augusto, 7), e criticava suas origens familiares (SUETÔNIO, Augusto, 1; 4), já que o príncipe descendia de uma linhagem equestre da família dos Octavii. Aqui cabe ressaltar que a demonstração da inferioridade de Otaviano/Augusto, apesar de ser filho adotivo de César, servia justamente para a encenação do poder no intuito de arranhar sua imagem pública e sua auctoritas.

Plutarco é outro autor que nos apresenta a relação entre Marco Antônio e Otaviano (a quem ele chama de César desde sua entrada na cena política romana em 44 a.C.) como conturbada desde o princípio. O biógrafo aponta que Marco Antônio era contra a tomada de Otaviano dos negócios públicos e de sua herança de César. Esse desprezo de Marco Antônio foi a razão pela qual Otaviano se aproximou de Cícero para tentar vencer o então cônsul romano, o que se deu na batalha de Módena, em 43 a.C.. No entanto, como nos aponta Plutarco, o fato de Cícero querer apenas a restauração dos negócios públicos foi o que causou a aproximação de Otaviano com Marco Antônio e Lépido e o subseqüente estabelecimento do acordo do Triunvirato e das proscrições (PLUTARCO, Marco Antônio, 19-21).

Como Dion Cássio nos apresenta, após as questões 'pessoais' terem sido resolvidas por cada um dos triúnviros, ou seja, Otaviano ter vencido Sexto Pompeu e Marco Antônio ter lutado contra os partos, apesar de sua derrota, e ter vencido os armênios, que os dois amigos de Triunvirato passaram a se tornar rivais e a disputar entre si a primazia política (DION CÁSSIO, História Romana, L, 1). O ano era 36 a.C.. Como Pelling aponta, esse ano é crucial 
para entendermos a reestruturação do Triunvirato, já que na cena política agora existiam apenas dois membros do acordo inicial, visto Lépido ter sido excluído por Otaviano das prerrogativas da magistratura que partilhavam, e também por cada um deles estar agindo em um pólo diferente do Mediterrâneo, Otaviano no Ocidente e Marco Antônio no Oriente (PELLING, 2001, p.66). Também não podemos deixar de ressaltar que esse ano foi importante para a teatrocracia política, pois a partir dele as auctoritates passaram por mudanças, com Otaviano se sobrepondo a Marco Antônio, que era quem detinha maior auctoritas, principalmente após as ações na batalha de Filipos, em 42 a.C..

\section{A degeneração dos padrões civis e o compromisso com a República}

Passemos agora ao segundo elemento presente no fragmento de Suetônio: a acusação de degeneração dos padrões civis. Isso deve ser compreendido dentro de um panorama geral de desestruturação da República romana e de acirramento das relações entre os senadores de Roma, devido à expansão das fronteiras romanas pelo Mediterrâneo, o que causou também um maior contato com referenciais culturais diferentes do mos maiorum.

Um primeiro ponto que devemos abordar é: o que seria esse padrão moral dos romanos, o mos maiorum? Os costumes dos antepassados, ou seja, o comportamento exemplar das gerações anteriores do povo romano, os mores, nos é sempre apresentado como sendo um elemento muito importante para os romanos. De acordo com Daviault, ele seria o regulador de toda a vida pública, dizendo respeito a um conjunto de comportamentos de diversas áreas da atividade humana: militar, política, técnica, intelectual e religiosa; uma espécie de promoção de uma identidade coletiva com referenciais destinados a se sobreporem aos valores individuais, sendo seus objetivos a coesão, a inspiração e a imitação (DAVIAULT, 1996, p.59-65). Portanto, esse arcabouço moral visaria ser uma forma de colocar a República acima dos interesses pessoais de cada um daqueles que estavam investidos de magistraturas. A partir disso, não podemos deixar de abordar a face política do mos maiorum. Mais do que apenas uma regra de conduta, era o suporte da dominação aristocrática, pois permeava todos os elementos cívicos, como a Religião e o Direito, por exemplo, e de gerência dos negócios públicos, cabendo aos censores, magistrados romanos, a observação de seu cumprimento.

Daviault também aponta que a cultura do mos maiorum não era avessa às inovações, naturais aos contatos entre sociedades e dá como exemplo disso as mudanças ocorridas 
durante a República no espaço urbano de Roma, em que adaptações foram necessárias, mas sob a vigilância daquilo comumente aceito. $\mathrm{O}$ autor argumenta que o conservadorismo aristocrático mascarou a necessidade de mudanças das estruturas romanas numa fase de expansão, mas não era totalmente avesso às adaptações, que sempre ocorreram, das estruturas romanas na sua posição expansionista (DAVIAULT, 1996, p.63-71). O problema foi o temor aristocrático de perda do domínio político.

Dentro desse ambiente político agitado que foi o último século da República, principalmente após os tribunatos dos irmãos Gracos, observamos uma maior utilização dos padrões dos antepassados como instrumento de crítica de determinado setor aristocrático mais conservador aos seus opositores. Podemos tomar como exemplo desse movimento de acusações da elite senatorial à corrupção dos costumes antigos a descrição de Salústio presente em sua obra sobre a conjuração de Catilina ${ }^{10}$. O autor traz não apenas um retrato do personagem central da narrativa, Lucio Catilina, um homem de origem nobre, porém que tinha mais vícios que virtudes, de acordo com o autor (SALÚSTIO, Conjuração de Catilina, 5), mas também um relato sobre a situação do mundo romano naquele período de expansão. Salústio apresenta uma Roma corrompida pelo luxo e pela cobiça, em que os cidadãos não se preocupavam mais com o bem coletivo, mas sim com os interesses individuais, mesmo que isso causasse o fim da República ${ }^{11}$. Assim, Catilina é inserido em um contexto nefasto em que a Urbs se encontrava (SALÚSTIO, Conjuração de Catilina, 5, 10, 53). A República que estava "transformando-se paulatinamente, tornou-se da mais bela e melhor das repúblicas na pior e mais vergonhosa de todas" (SALÚSTIO, Conjuração de Catilina, 5), o que em muito se aproxima das palavras de Cícero,

\footnotetext{
“Antes da nossa época, vemos a força dos costumes elevar varões insignes, que por sua parte procuravam perpetuar as tradições dos antepassados. Nossa idade, pelo contrário, depois de ter recebido a República como uma pintura insigne, em que o tempo começara a apagar as cores, não só não cuidou de restaurá-la, dando novo brilho às antigas cores, como nem mesmo se ocupou de conservar ao menos o desenho e os últimos contornos. Que resta daqueles costumes antigos, dos quais se disse terem sido a glória romana? O pó do esquecimento que os cobre impede, não já que sejam seguidos, mas conhecidos. Que direi dos homens? Sua penúria arruinou os costumes; é esse um mal cuja explicação foge do alcance da nossa inteligência, mas pelo qual somos responsáveis como por um crime capital. Nossos vícios, e não
}

\footnotetext{
${ }^{10}$ A conjuração de Catilina ocorreu no ano de 63 a.C., durante o sempre lembrado consulado de Cícero, o cônsul responsável por conter a revolta de um pequeno grupo de aristocratas, conjuntamente com membros de outras esferas sociais, liderados por Catilina, contra as instituições republicanas.

${ }^{11}$ Conforme Salústio, o começo dos anos ruins, que vieram com o afrouxamento dos costumes, se deu com as ações do exército de Sila na Ásia (uma região muito rica do Mediterrâneo, onde se localizava Pérgamo) que se habituara ao luxo e a uma disciplina indulgente, em que as práticas de roubar e pilhar eram comuns (SALÚSTIO, Conjuração de Catilina, 11).
} 
outra causa, fizeram que, conservando o nome de República, a tenhamos já perdido por completo" (CÍCERO, Sobre a República, V, 1).

Ambos os relatos, bem como as críticas de outros membros da elite aristocrática romana, têm seus limites, pois nos apresentam um olhar específico, obviamente, algo inerente a todo relato humano, no caso o olhar aristocrático, porém, ele ilustra bem o pensamento de uma parcela da elite que via seus pilares de dominação serem minados por membros da própria elite. Os poucos que comandavam a República, justificativa que é colocada na boca de Catilina como a razão para a sua conjuração, ou seja, o fato de o poder da República romana ter caído nas mãos de poucos (SALÚSTIO, Conjuração de Catilina, 20), viam os poderes republicanos em xeque por essas novas camadas sociais, como os soldados, que vinham ganhando muito prestígio com a expansão romana, pela plebe sempre propícia a agitações populares e por membros da própria aristocracia que com o comando militar ganhavam um grande prestígio face ao poder dos patres.

Galinsky argumenta que o problema republicano era o desvio moral. Os autores antigos viam a República em perigo não por causa da deturpação ou 'declínio' dos mores, o pilar central de sustentação do sistema republicano e, consequentemente, da aristocracia romana, em si, mas no descompasso das ações dos homens romanos que usavam o público em prol de seus interesses privados e não do modo contrário, visando à coletividade, como deveria ser. Com isso, essa corrupção dos homens afetava toda a coletividade, que vinha a compartilhar daqueles elementos culturais e sociais. Segundo o autor, os antigos afirmavam que era necessário um retorno a utilização dos mores pelos homens romanos, ou seja, uma espécie de moralização social. O que demonstra isso é o fato de Augusto se consolidar na cena política romana, apesar de todas as alterações feitas por ele no sistema políticoadministrativo dos negócios públicos, justamente com o discurso e ações que remetessem a um retorno dos costumes dos antepassados, voltando a mise en scène a ser regida pelo mos maiorum (GALINSKY, 1996, p.58-59). O Principado só foi aceito pela elite dirigente romana pelo fato de o novo governo estar fundado no retorno ao passado e num respeito ao mos maiorum, o que podemos ver através dos autores da época, como Horácio, Virgílio e nas res gestae do príncipe. Aparência republicana e reafirmação dos valores antigos, ao menos no discurso, eram as palavras de ordem. E aqui devemos ter cuidado para não tomar os escritos de uma parcela da sociedade como um plano generalizado. O que temos é um discurso consciente de setores sociais no interior da disputa política, o qual foi apropriado por Otaviano/Augusto e difundido pelos autores contemporâneos ou posteriores. O herdeiro de 
César soube se utilizar dos instrumentos que tinha em mãos para se apresentar em sua encenação política, a qual não deve ser encarada tão inocentemente.

A sociedade romana havia um século que enfrentava uma grande desordem política interna com a transformação dos problemas sociais advindos, principalmente, da expansão de suas fronteiras, em querelas políticas internas, como expõe Alföldy (1989, p.81-109). Nesse cenário, uma parcela da aristocracia tomou a moralização, seja como plano de acusação dos rivais, seja como instrumento para justificar suas atitudes no cenário romano, seja como suporte político.

Para alguns romanos, os elementos que os uniam não eram propriamente uma questão cultural. Claro que não podemos deixar de reforçar o grande papel exercido pelo mos maiorum junto à sociedade romana e como ele, mesmo durante o período imperial, foi um grande freio para as ações sociais dos romanos. Mas ele era muito mais um pilar da dominação de um determinado setor social do que algo compartilhado por todos os membros da sociedade romana. Não era o seguimento ou não do mos maiorum que permitia a um romano agir politicamente. Isso lhe era permitido pela posse da cidadania romana. Ser cidadão romano, pertencer a ciuitas romana, que era o elemento distintivo entre os romanos. De acordo com Nicolet, “(...) o cidadão é, pela própria natureza das coisas, um soldado que pode ser mobilizado, um contribuinte, um eleitor e eventualmente um candidato a determinadas funções", sendo a cidadania romana mais do que um modo de vida, o que era representado pelo mos maiorum, ou um ofício, sendo um estatuto jurídico (NICOLET, 1992, p.24-26). Um estatuto jurídico essencial, tanto que ela foi a moeda de troca, ao menos até o edito de Caracala, em 212 d.C., para que as elites locais aderissem à causa romana e se tornassem, ao menos mais pacificamente, os sustentáculos locais da dominação romana ${ }^{12}$.

O caso de Ênio, citado por Wallace-Hadrill, é muito interessante. Ênio era osco de nascimento, compartilhava de uma identidade cultural grega, mas era um cidadão romano. De acordo com o autor, nenhuma das três identidades era excludente; as três poderiam ser coexistentes, pois cada uma dizia respeito a uma esfera de ação do indivíduo (WALLACEHADRILL, 2008, p.3), não sendo necessário saber falar latim perfeitamente. Obviamente que aqui esbarramos na etiqueta social pré-estabelecida pelo mos maiorum em que um romano não poderia, mesmo que possuidor de uma matriz cultural grega, deixar que esta interferisse na sua correta ação em prol da coletividade romana. Foi justamente o que ocorreu com os

\footnotetext{
${ }^{12}$ Para uma interessante análise sobre a cidadania romana, as implicações de ser ou não cidadão romano nas províncias e os status das cidades provinciais (ciuitates perigrinae) ou cidades romanas nas províncias (municipia ou coloniae), Cf: HASSALL, 2002, p.685-698.
} 
aristocratas dos séculos II e I a.C. considerados nefastos à República, bem como com os aristocratas, senadores ou membros da domus imperial, como, por exemplo, Júlia, a filha de Augusto, ou Calígula e Nero, fora dos padrões morais. Então, o mos maiorum não era o vetor de ação, não era o que contava, mas a forma de agir deveria segui-lo, pois seria o suporte para as críticas dos senadores, visto os relatos aristocráticos, em sua maioria, serem permeados por essa visão política-moral.

Dentro desse contexto de agitação política e de críticas de não seguimento do mos maiorum por alguns membros da elite aristocrática romana, como observamos pelas palavras de Salústio e Cícero acima, temos mais um elemento a inserir na análise. Muitas das acusações se referiam a um relaxamento moral devido à adoção de práticas culturais como as advindas do mundo oriental, principalmente da Grécia, como o gosto pelo luxo, por exemplo. Os séculos II e I a.C. foram os quais os romanos expandiram as fronteiras de sua República pelo Mediterrâneo e conquistaram um gigantesco império territorial. Obviamente que nesse processo muitas trocas culturais foram realizadas, até porque muitos dos principais magistrados da República estiveram lutando em diferentes regiões do Mediterrâneo sob os estandartes romanos.

No entanto, devemos tomar cuidado para não pensarmos que as fontes nos mostrem uma visão unânime sobre a ameaça dos conhecimentos ou comportamento dos estrangeiros, principalmente com relação ao modus vivendi dos gregos, principal padrão cultural difundido no Mediterrâneo antigo, sobre o mos maiorum romano. A admiração romana pelos costumes gregos não era desprovida de críticas. Havia uma censura muito grande ao modus vivendi grego, visto por alguns como imoral devido ao gosto dos gregos pelo luxo e pela licenciosidade. Contudo, como aponta Branigan, a resistência aos elementos estrangeiros advindos do mundo grego não incluíam uma resistência à língua, à literatura ou à educação grega clássica, mas sim à cultura helenística, que já possuía elementos das culturas nativas dos povos mediterrânicos, vista como inferior à cultura romana, tendo como base o mos maiorum (BRANIGAN, 2002, p.42). Como dito, há muito mais um perigo político por se desestruturar uma forma de governo nas mãos de poucos do que de fato um medo de que os conhecimentos romanos fossem corrompidos por aqueles advindos do exterior.

Turcan, ao analisar as religiões orientais, mostra como elas se entremearam no interior do corpo romano, advindas dos contatos com pessoas de mais fácil circulação pelo Mediterrâneo, coexistindo com a religião oficial da Urbs (TURCAN, 1989, p.8-33). WallaceHadrill, em sua obra 'Rome's Cultural Revolution', discorre sobre a utilização desses contatos com os greco-orientais pelas elites italianas em sua disputa com a elite de Roma por maior 
espaço no cenário político da República, fazendo com que essas idéias e objetos advindos do Oriente compusessem seus discursos, ações, construções e objetos em busca de seus objetivos político-sociais dentro da SPQR, o que se dava sem se corromper o mos maiorum, pois o que se operava era uma forma diferente de absorção e apropriação pelo discurso político dos senadores de Roma ${ }^{13}$. Como o autor muito bem aponta, a cultura romana que conhecemos é uma cultura da elite, sendo necessário um trabalho mais cuidadoso para se ter uma visão mais global da pluralidade cultural do mundo romano com a inserção de outros elementos na (re)construção desse cenário cultural (WALLACE-HADRILL, 2008, p.11-12). Os textos nos apresentam muito mais uma descrição da gestão política do que propriamente uma recomposição de todos os traços culturais romanos, o que torna a análise historiográfica mais complexa, pois para a reconstrução do cenário precisamos de objetos de naturezas diferentes.

Os romanos empreendiam, na maioria das vezes, uma releitura através da adaptação, modificação e transformação das idéias, estilos e técnicas gregas (BRANIGAN, 2002, p.42). Cícero aponta que o verdadeiro valor da sabedoria dos antepassados foi transformarem as coisas tomadas do exterior em melhor do que o eram a princípio, sendo a prudência e a disciplina, conjuntamente com a fortuna, as razões do esplendor dos romanos, não sendo fruto do acaso, pois não foram as coisas importadas do além mar, mas as virtudes domésticas, seguidas pelos principais varões, que elevaram a República (CÍCERO, Sobre a República, II, 15-16). Como aponta Momigliano, "os intelectuais gregos e romanos tiveram de aprender que em Roma a helenização subentendia respeito pela ordem dominante" (MOMIGLIANO, 1991, p.24). Segundo o mesmo autor,

"Roma, não a Grécia, preparou as condições que iriam tornar as relações entre
ambas um caso tão especial. Os gregos não foram além daquele mínimo de atenção
que a sua posição exigia (...). Os romanos resolveram decifrar os gregos, tentaram
aprender a língua, aceitaram deuses gregos (...). Os gregos não reagiram - ou
melhor, não foram além da superfície da vida romana - até se acharem diante de
uma potência de primeira classe que derrotara os exércitos gregos de Pirro em
campo aberto" (MOMIGLIANO, 1991, p.20).

Um exemplo disso é o uso da língua grega como um instrumento de poder muito utilizado pela maioria dos magistrados romanos em suas ações políticas. Ela era a língua franca na região oriental do Mediterrâneo, tanto nas cidades, quanto nos reinos helenísticos e deveria ser aprendida para um bom estabelecimento dos contatos durante as expansões, com comerciantes, escravos e habitantes locais, o que demonstra um contato além do interno com

\footnotetext{
${ }^{13}$ A helenização da península Itálica, de acordo com o autor, era um processo indissociável da romanização, visto que se adotava a paideia (língua e modo de vida) sem abandonar o costume dos antigos (WALLACEHADRILL, 2008, p. 19-26, 58).
} 
os professores de grego. Um magistrado romano deveria ser capaz, o que não pressupõe que todos o eram, de falar em grego e em latim, sendo através disso buscada uma superioridade e afirmação da identidade latina sobre a grega ${ }^{14}$.

Wallace-Hadrill também nos demonstra outro exemplo desse processo de releitura dos elementos estrangeiros gregos através da apresentação de como foi criado entre os romanos um sistema de honras como premiação para os bons feitos realizados em prol da República semelhante, apesar da leitura ter se dado de modo romano, àquele existente, por exemplo, em Atenas (WALLACE-HADRILL, 2001, p.51-84).

Dessa forma, tomado esse panorama, muitos romanos foram vítimas das críticas morais de determinados grupos senatoriais que os enxergavam como ameaças à República romana, construindo assim um retrato moral nefasto, ressaltando ou talvez até mesmo criando pontos negativos do comportamento social desses homens, algo não apenas visível na República, mas também no Império como bem sabemos através das nossas fontes que acabam por promover uma damnatio memoriae de alguns imperadores através de seus escritos. Podemos citar da época republicana os irmãos Gracos, César e Marco Antônio como exemplos de homens que estiveram em algum momento no centro da cena política e sofreram críticas, foram alvos da escrita aristocrática moralizante, muitos outros de menor importância na história política romana também tiveram seus retratos realizados sob esse olhar, positiva ou negativamente. Portanto, Marco Antônio, para tomarmos mais explicitamente nosso objeto de análise, se insere num contexto de críticas que tomavam o comportamento social como um elemento central para difamações.

Inicialmente, não podemos deixar de ter em mente que o processo de (des)construção da imagem de Marco Antônio se deu em duas fases diferentes e com planos discursivos também diferenciados, o que não nos permite enxergar Marco Antônio puramente como um homem degenerado, mas como alguém que, por estar na cena pública, foi alvo de críticas em determinadas épocas. Cabe a nós entendermos cada fase e observar quais as críticas elencadas. Como Bloch expõe, não cabe ao historiador um julgamento do passado, mas sim uma análise criteriosa sobre as fontes, buscando trazê-las a luz e apresentar seus reais, quando possível isto, propósitos (BLOCH, 2002, p.125-128).

\footnotetext{
${ }^{14}$ Momigliano insiste na importância da capacidade de expressão em língua grega na época helenística. De acordo com o autor, os bárbaros deveriam se expressar em grego para que pudessem ter voz dentro desse cenário cultural grego que se espalhou pelas terras orientais do Mediterrâneo. Ele aponta a pouca importância dada pelos gregos a um real conhecimento dos bárbaros que eles estavam dominando, sendo a visão sobre os povos nativos muito estereotipada. A sagacidade romana foi agir de modo diferente dos gregos, do mesmo modo que os bárbaros agiram, usando a língua grega para se expressarem nesse mundo antigo, mesmo após a conquista militar dessas regiões (MOMIGLIANO, 1991, p.13-14).
} 
Um autor antigo que foge à regra é Plutarco, em sua biografia sobre Marco Antônio, escrita no século II d.C., pois ele nos relata que o comportamento degenerado do romano se iniciou em sua adolescência, quando do contato com companhias não tão positivas, como Curio e Clódio (PLUTARCO, Marco Antônio, 2) e que isso foi evoluindo com o tempo. Até mesmo quando já ocupava funções públicas, como é o caso de quando era chefe de cavalaria de César, fazendo com que este preferisse a Lépido como colega de consulado quando retornou da Espanha, em 46 a.C. (PLUTARCO, Marco Antônio, 9-10). Assim sendo, Plutarco faz uma leitura de algo pontual como estrutural, tornando algumas características que poderiam ter sido observadas no comportamento do biografado em determinados momentos ou de discursos específicos como algo presente em toda a vida de Marco Antônio. Não devemos deixar de ressaltar mais uma vez que isso se deve a própria estrutura e objetivo de suas biografias que eram de descrever as ações de um homem romano e um homem grego através de um quadro moral e posteriormente comparar suas ações.

A primeira das duas fases de (des)construção do retrato de Marco Antônio coube a Cícero. Entre os anos de 44 e 43 a.C. o orador romano foi responsável pelo conjunto de quatorze discursos conhecido como 'Filípicas', pronunciados tanto no Senado quanto para o povo, em que o autor faz ataques diretos ao então cônsul em 44 a.C., quando dos quatro primeiros discursos, e senador romano, quando dos dez seguintes, Marco Antônio.

A motivação inicial da primeira 'Filípica' foi um discurso de Marco Antônio no Senado reclamando da ausência de Cícero, que havia acabado de retornar da Grécia, para onde fugira durante as agitações do funeral de César, e de ter ameaçado ir até a casa dele e destruí-la (CÍCERO, Filípicas, I, 5). Sendo assim, o tom de Cícero é moderado neste discurso inicial proferido no Senado logo no dia posterior aos ataques do cônsul, apesar das injúrias, que é como ele denomina as palavras proferidas contra ele, recebidas. O orador romano se defende das acusações alegando ser permitida a ausência às reuniões do Senado e que ele rogava “[...] ao menos de me tratar, em sua cólera, como um cidadão", visto Marco Antônio ser um homem perigoso e armado (CÍCERO, Filípicas, I, 11). No entanto, essa primeira 'Filípica' mais elogia o cônsul do que o critica. Cícero, logo no princípio de seu discurso, louva o ato de extinção da ditadura promovido por Marco Antônio que assim afastava o mal da força do poder real das instituições romanas, visto a memória da ditadura de César ainda estar muito viva, sobretudo entre os senadores de oposição, como é o caso do orador (CÍCERO, Filípicas, I, 1). E no interior de sua fala afirma sobre Marco Antônio e sua relação com ele, "[...] do qual eu sou amigo. [...] eu sempre o reconheci altamente" (CÍCERO, 
Filípicas, I, 4), mas "qual então o motivo desta mudança repentina? [...] Eu nunca reconheci em você nada de vil nem de sórdido" (CÍCERO, Filípicas, I, 13). Ora, temos nessa fala inicial de Cícero uma visão positiva de Marco Antônio e o reconhecimento de que ele possuía traços de qualidade, não sendo apenas um mal à República. Contudo, isso não se mantém nos discursos posteriores quando os ataques se tornam diretos e as acusações de que Marco Antônio era um mal à República e que desejava instaurar uma tirania sobre ela começam a ser proferidos.

Para se entender o porquê da mudança do teor dos discursos subsequentes, devemos entender quais as razões que levaram Cícero a proferi-los. A segunda 'Filípica' também é uma resposta a um discurso de Marco Antônio em que o cônsul abordava sua inimizade com o orador e pode ser dividida em duas partes, a primeira seria a defesa de Cícero às acusações sofridas e a segunda um conjunto de críticas a vida (pública e privada) de Marco Antônio. O seu tom é bem diferente da primeira e já mostra uma oposição entre os dois, sendo objetos do plano discursivo elementos que construíam uma visão de Marco Antônio como um mal à República e a causa de todas as agitações que a Urbs passara com César e estava passando naquele momento posterior ao seu assassinato.

As palavras de Cícero nos mostram um homem cheio de vícios, isso desde quando vestira a toga civil. Sua juventude e seu cursus honorum, principalmente seu consulado, que ainda estava sendo exercido quando deste discurso, foram desonrosos para os romanos (CÍCERO, Filípicas, II, 17-21). No entanto, o ápice da descrição de Cícero é quando Marco Antônio é apresentado como o pomo da discórdia entre Pompeu e César e acusado de ser o causador da guerra civil e de todos os males à República advindos do confronto entre os dois antigos triúnviros. Cícero chega a comparar Marco Antônio a Helena de Tróia (CÍCERO, Filípicas, II, 22). Dos discursos, este é o que há os maiores ataques a imagem de Marco Antônio, uma vez que procura fazer um panorama difamatório, mostrando os vícios e os males à República que causavam o então cônsul.

Os discursos posteriores seguem a mesma linha e buscam trazer o cônsul como nefasto à República, sendo que Cícero se justifica quanto aos ataques: “[...] nós podemos à minha voz e ao meu exemplo nos aquecer da esperança da liberdade" (CÍCERO, Filípicas, IV, 6). O então cônsul passa a ter seu retrato construído como o de um homem que visava escravizar a República e aos seus concidadãos, causando males à libertas romana, pois, de acordo com Cícero, “[...] ele não sonha nada menos [do] que [com] a ruína da República" (CÍCERO, Filípicas, IV, 2), sendo que “[...] uma dominação não só cruel e soberba, mais ainda desonrosa e criminal pesa sobre nós. Vocês [pais conscritos] conhecem a insolência de Marco 
Antônio, seus amigos, vocês conhecem toda sua casa. Debochados, insólitos, impuros, impudicos, jogadores, bêbados [...]” (CÍCERO, Filípicas, III, 14). O orador até faz uma comparação entre Marco Antônio e Tarquínio, o soberbo, apontando que este tinha mais pontos positivos que aquele (CÍCERO, Filípicas, III, 4), o que é muito simbólico, visto o último dos reis romanos não ser tão bem estimado na história romana.

Entretanto, o que mais nos interessa nesses discursos é como Otaviano é inserido neles. Um primeiro ponto a ser tocado é o fato de Cícero apenas chamar o jovem de C. César, o que demonstra uma escolha bem estruturada no intuito de diminuir a auctoritas de Marco Antônio, que não possuía boas relações com Otaviano. Assim, o orador se mostra concordante com a adoção testamentária de Otaviano por César e acaba por aumentar a respeitabilidade do jovem herdeiro junto a certo setor do Senado. E segundo, a forma como Cícero descreve Otaviano, reforça ainda mais tais intenções, pois ele constrói Otaviano em oposição a Marco Antônio. O orador romano começa por insuflar os senadores romanos a decretarem honras a Otaviano por sua ação virtuosa contra o cônsul, sendo um adolescente corajoso e com inspiração divina que havia salvado a República (CÍCERO, Filípicas, III, 2). "Ele é, de fato, um adolescente mais casto, mais moderado? Que seja, para nossa juventude, um ilustre modelo da antiga austeridade dos costumes? Também qual ser mais impuro que seu caluniador [Marco Antônio]?” (CÍCERO, Filípicas, III, 6). Desse modo, Cícero se utiliza de Otaviano como objeto de suas críticas a Marco Antônio. Claro que para o jovem herdeiro de César isso acaba sendo muito positivo, pois ele aos poucos vai aumentando sua auctoritas, porém, saber como ele próprio se utilizou das palavras de Cícero em sua época se torna um pouco difícil ${ }^{15}$. Já diante do povo, no início de sua fala, o orador argumenta: “C. César que de seu zelo, de sua sabedoria, de seu patrimônio enfim, sustentou e ainda sustenta a República e vossa liberdade" (CÍCERO, Filípicas, IV, 1), o que nos mostra como também junto ao povo ele buscou construir tal oposição e valorização do jovem herdeiro de César.

Os demais discursos das 'Filípicas' continuam dentro de um prisma difamatório de Marco Antônio, mas agora através de críticas do desejo de possuir a Gália e o incentivo para que o Senado, sobretudo através das figuras dos cônsules de 43 a.C., A. Hírcio e C. Pansa, o considerassem um inimigo público do povo romano. Cícero toma outro personagem como ponto de comparação, C. Bruto, que estava em posse da desejada província gaulesa segundo uma denominação senatorial anterior. O orador romano procura sempre colocar Bruto como

\footnotetext{
${ }^{15} \mathrm{O}$ trecho inicial de suas res gestae (I, 1) tratam justamente desse período, falando do exército pessoal que havia vencido uma facção que oprimia a República. No entanto, o discurso do príncipe mascara algumas das formas como se deram os acontecimentos nessa época.
} 
um personagem exemplar e bem-feitor para a República, enquanto Marco Antônio era apenas capaz de causar males. O interessante é visualizar como a cada discurso fica mais evidente a limitação das críticas a Marco Antônio e como aquele ponto de vista não era consensual nem entre os senadores.

Esses discursos de Cícero tiveram um grande impacto no mundo romano, tanto que Plutarco e Dion Cássio os citam, séculos depois. No entanto, de modos diferentes, em suas obras; o primeiro através de uma breve referência quando da apresentação das ações de Marco Antônio no contexto da invasão da península Itálica por César, discordando da posição do orador romano de que Marco Antônio havia sido o pomo da discórdia entre César e Pompeu e afirmando que a fuga dele para a Gália serviu apenas de pretexto para as ambições de César (PLUTARCO, Marco Antônio, 6) ${ }^{16}$, enquanto o segundo faz a construção de um discurso, no interior de sua narrativa, com uma síntese das críticas contidas nas 'Filípicas', o que toma grande parte de um de seus livros (DION CÁSSIO, História Romana, XLV, 18-47).

Entretanto, não devemos deixar de demonstrar qual é o local de fala de Cícero. Ele era um senador romano de oposição aos populares, sempre preocupado com a moralidade da sociedade romana e com a República. Sua visão contrária a Marco Antônio, como podemos observar através de suas próprias palavras não era algo unânime, sendo apenas uma das visões possíveis a respeito dele. As críticas foram motivadas pelo próprio modo de observar o mundo de Cícero, sempre temeroso de que o poder da República se desfizesse e que um homem sem virtudes tomasse as rédeas da cena política, tomando sua concepção de República e o moralismo dos optimates como base.

Um autor antigo que nos mostra como a visão de Cícero era um dos modos de se analisar Marco Antônio é Dion Cássio. O autor romano dedica um grande fragmento de sua 'História Romana' para trazer aos seus leitores as diferentes visões existentes a respeito de Marco Antônio. No livro 45 de sua obra, temos um logo texto de atribuição a Cícero do que seria um dos seus discursos das Filípicas, mas, na verdade, temos Dion Cássio fazendo uma espécie de resumo dos discursos e colocando essas palavras na boca de Cícero através de como teria sido ele falando isso perante os senadores (DION CÁSSIO, História Romana, XLV, 18-47). Tais palavras são o encerramento de seu livro 45 sobre os eventos posteriores à morte de César em 44 a.C..

\footnotetext{
${ }^{16}$ De acordo com Plutarco, a inimizade entre Marco Antônio e Cícero surgiu pela acusação do padrasto de Marco Antônio na lista de conjurados de 63 a.C. (Conjuração de Catilina) e a subsequente recusa do então cônsul Cícero em liberar o corpo para os ritos funerais (PLUTARCO, Marco Antônio, 2).
} 
Ao ler apenas esse livro de Dion Cássio, poderíamos pensar que o autor buscava construir somente um retrato nefasto de Marco Antônio, o que é reforçado pelo longo trecho dedicado ao discurso de Cícero, porém, não é o que ocorre. O livro 46 se inicia com um discurso que seria uma espécie de resposta. Dion Cássio usa Caleno ${ }^{17}$ para tal ação. Através das palavras do autor romano atribuídas a Caleno, temos a exaltação de feitos de Marco Antônio pela República e uma crítica direta a Cícero, tanto de sua vida pública quanto da pessoal, buscando assim desconstruir tudo o que havia sido dito anteriormente (DION CÁSSIO, História Romana, XLVI, 1-28). De acordo com Millar, o discurso de Cícero seria composto por fragmentos das 'Filípicas' II, III e V, enquanto o discurso de Caleno seria uma construção narrativa ficcional empreendida pelo historiador da Bitínia, que poderia ter sido apropriado de alguns autores da época imperial contrários a Cícero. O autor também aponta que não podemos nos apropriar de nenhuma base histórica dos dados apresentados nesse diálogo entre Cícero e Caleno (MILLAR, 1961, p.18-22).

A nosso ver, a forma como Dion Cássio busca apresentar Marco Antônio é muito interessante. Este não é apenas o único exemplo, temos os discursos dos triúnviros aos seus exércitos durante a fase preparatória para a batalha do Actium como outro caso do uso desse artifício discursivo do autor. Dion Cássio não faz acusações diretas a Marco Antônio. Nos dois momentos temos sempre terceiros falando, o que mostra certo receio de uma tomada de posição. O que para nós historiadores é muito significativo, pois assim ele acaba por nos apresentar muitos elementos para análise, que, de certo modo, fugiam apenas do discurso do vencedor.

Apesar de toda essa dinâmica difamatória de Cícero, o seu trabalho não lhe rendeu nada, a não ser a punição de sua mão ser exposta no Fórum romano, por mando de Marco Antônio, após ter sido assassinado (PLUTARCO, Cícero, 42-49). O próprio estabelecimento do Triunvirato põe em xeque a visão negativa de Cícero com relação a Marco Antônio, pois Otaviano busca a ele como aliado, não aos senadores que tramaram a morte de César. Temos assim uma questão: Como um homem que era visto como um mal à República poderia ser um dos homens capazes de restaurá-la? A cena política é muito mais complexa e permeada de interesses.

Já a segunda fase de críticas a Marco Antônio se dá, sobretudo, após 36 a.C. e está intimamente relacionada às ações do triúnviro romano no Oriente. As críticas de Otaviano a

\footnotetext{
${ }^{17}$ Quinto Fúfio Caleno era partidário de César, tanto que lutou com ele na Gália. Após o assassinato do antigo ditador se aliou a Marco Antônio. Morreu em 40 a.C., quando era governador da Gália. Foi cônsul em 47 a.C..
} 
Marco Antônio se dão mais fortemente na segunda metade do Triunvirato, primeiro, por estarem apenas os dois compartilhando a magistratura, visto Lépido, que sempre pendeu mais para Marco Antônio, ter sido afastado de suas funções, em 36 a.C.; segundo, por além de estar em uma 'disputa' mais aberta e pessoal, Otaviano possuía uma auctoritas mais elevada que a do seu colega de magistratura devido a sua vitória contra Sexto Pompeu e à derrota daquele perante os partos. Assim, o que em 42 a.C. parecia consensual de que Marco Antônio era o mais poderoso acabou por se modificar devido aos acontecimentos de 36 a.C..

Essa segunda etapa de (des)construção da imagem de Marco Antônio por Otaviano deve ser vista como gradual e indireta, apesar das acusações que ele efetuou junto ao Senado com as notícias dos acontecimentos e ações de Marco Antônio no Oriente, mais especificamente em Alexandria, como nos narra Plutarco. A linha difamatória desse período buscou mais do que apresentar Marco Antônio como um homem nefasto à República e um possível tirânico, como o fez Cícero. O que se procurou trazer para a cena política foi mostrálo como um estrangeiro, um homem que não mais se preocupava com a Urbs, seja pela adoção dos costumes asiáticos ou egípcios, seja pelo favorecimento de Cleópatra e do Egito com doações e honras. Traduzir Marco Antônio de fato como o outro era significativo para o próprio reforço do discurso de Otaviano de que suas ações eram em prol da República romana.

Desse modo, devemos ter cuidado com os dados que possuímos sobre essas ações de Marco Antônio fora de Roma e inseri-los dentro da teatrocracia política do Triunvirato. Algumas ações ocorreram devido às necessidades impostas pelas ocasiões e pela atuação nos cenários políticos do Mediterrâneo. Os autores antigos se apropriaram desses eventos para a composição de suas narrativas sobre o passado romano como cabia a cada um, sendo muitos desses escritos influenciados pelo conjunto de informações depreciativas de Marco Antônio advindas do discurso do vencedor, Otaviano, o que fazia com que um fosse apontado mais positivamente, enquanto o outro mais negativamente.

A posição de Otaviano perante a sociedade romana era muito delicada. Primeiramente por ter uma auctoritas inferior ao rival; segundo, por se encontrar muito mais próximo do Senado e dos demais setores sociais romanos, já que residia em Roma, o que o colocava em perigo por eventualmente poder ocorrer alguma oposição mais direta, sobretudo dos setores militares, a sua pessoa na Urbs, mas o que também foi crucial para que ele conseguisse ser visto como defensor de Roma e seguidor dos mores romanos, já que ele agia na península Itálica e na Urbs. Tomando isso, entendemos o porquê de todo um conjunto de críticas serem necessárias na (des)construção de Marco Antônio, desde seus hábitos no exterior até a atos 
nesses outros ambientes políticos mediterrânicos, principalmente Alexandria, pois Otaviano e sua posição de destaque na cena política romana era muito frágil e pouco consensual, algo que passa a se alterar após a vitória contra Sexto Pompeu e as honras recebidas, mas que precisa ser reforçada durante um espaço mais amplo de tempo.

Quanto a uma comparação entre os dois, Otaviano e Marco Antônio, o cenário é muito complexo e indireto. Alguns autores, como os que usamos de base para nossa pesquisa, não trabalham com a construção dos retratos deles em oposição de modo comparativo. Suetônio, por exemplo, mostra as cartas de Marco Antônio, porém, não constrói a imagem de Otaviano/Augusto a partir desses escritos, não se utiliza de uma desconstrução de Marco Antônio para mostrar a superioridade de Otaviano/Augusto, sendo esta estabelecida por outros meios em diversos campos de ação, tanto público, quanto privado, mas, principalmente, devido às próprias atitudes do herdeiro de César em prol do povo romano. Plutarco destaca a rivalidade entre eles, mas não faz uma comparação entre os dois triúnviros. Dion Cássio é o único que apresenta a oposição entre os dois, principalmente pelo modo como ele se apropria dessa oposição na construção de sua história romana, porém, é um olhar muito tardio em relação aos acontecimentos e seu texto possui uma natureza diferente das biografias de Suetônio e Plutarco, o que até justifica, de certo modo, as alternativas escolhidas para a narrativa das ações dos dois homens romanos.

As palavras do próprio príncipe em suas res gestae não nos trazem Marco Antônio, o que nos diz muito sobre a forma de construção da oposição entre eles nessa época. Não devemos deixar de nos lembrar que, de acordo com as suas próprias palavras, Augusto procurou em sua vida, e o que ele explicita ter conseguido, ser um exempla a ser seguido pelos demais romanos (Res Gestae, II, 8). Ora, esse pequeno fragmento já diz muito para os romanos e, indiretamente, arranha as imagens de rivais degenerados, como teria sido Marco Antônio.

Para entendermos melhor esse novo processo de (des)construção da imagem de Marco Antônio, um ponto que merece destaque em nossa análise é a sua estadia no Oriente. Esta está no centro de todas as críticas levantadas contra o magistrado romano na época do Triunvirato. No entanto, um primeiro ponto que não devemos deixar de frisar é que essa estadia oriental se deu em dois momentos específicos e que o Oriente se insere de duas formas possíveis dentro de nossa análise: como espaço físico de ação e como plano discursivo do outro. De acordo com a reorganização do pacto do Triunvirato após a batalha de Filipos, em 42 a.C., ocorreu uma nova divisão das províncias romanas entre os triúnviros, visto agora as antigas províncias 
que estavam em posse dos cesaricidas estarem vagas, grosso modo, as terras orientais ${ }^{18}$. Com essa nova divisão, Otaviano ficou com a Espanha e responsável por assentar os veteranos, Lépido com a África e Marco Antônio, segundo Pelling por possuir uma maior auctoritas, advinda principalmente das batalhas contra os exércitos de Bruto e Cássio (PELLING, 2001, p.8-9), ficou responsável pela Gália e por reorganizar o poder romano no Oriente.

Assim sendo, estar no Oriente ${ }^{19}$ em contato com reis e cidades daquela região era uma obrigação de Marco Antônio, pois cabia a ele reestruturar a dominação romana naquela área. Com isso, o Oriente se tornou um importante espaço de ação para o triúnviro. Ao se encontrar no Oriente, Marco Antônio acabou sendo obrigado a entrar nos cenários políticos exteriores e agir de acordo com a mise en scène de cada um deles e até mesmo de todos de um modo mais geral, e a associação dele com o deus Baco é um dos casos sempre destacados pelas fontes, por exemplo, dessa ação oriental.

No entanto, o problema era essa ação oriental se caracterizar numa quebra do seu compromisso com a Urbs. É a partir desse prisma que observamos as críticas de Otaviano a Marco Antônio. Cícero nos legou um retrato dele como um homem nefasto à sociedade romana, mas como Otaviano buscou explicitar uma degeneração dos padrões civis por Marco Antônio na segunda fase do Triunvirato? As ações dele poderiam ser vistas de vários modos, positiva ou negativamente, porém, quais delas podem ser consideradas, de fato, como exemplos de uma degeneração e de que forma foram utilizadas por Otaviano em sua disputa política?

No que concerne a essas estadias orientais de Marco Antônio, não podemos deixar de apontar que elas eram necessárias para a República romana. Elas se deram em duas fases. A primeira delas entre 42 e 40 a.C., logo após o estabelecimento do novo acordo. E a segunda estadia, a mais longa, foi entre 39 e 30 a.C., quando da sua morte ${ }^{20}$. Pelling aponta que essa ausência de Marco Antônio de Roma foi crucial para que Otaviano conseguisse implantar seu programa de difamação do seu rival (PELLING, 2001, p.9), o qual não estava presente para poder se defender. Um exemplo disso é a tomada do testamento de Marco Antônio e a sua leitura por Otaviano em Roma. Marco Antônio não possuiu meios de se defender já que se encontrava em Alexandria.

\footnotetext{
${ }^{18}$ Cássio estava, antes da batalha de Filipos, agindo na Síria, enquanto Bruto estava na Macedônia, Grécia e Ásia, ambos em busca de riquezas para que pudessem se defender dos então triúnviros.

${ }^{19}$ Cabe destacar que essa ida ao Oriente enquanto triúnviro não foi a primeira vez que Marco Antônio foi para essa região. Além de ter estudado na Grécia, ele também participou de guerras na Síria contra Aristóbulo e da restauração de Ptolomeu Aulete no trono alexandrino (PLUTARCO, Marco Antônio, 3).

${ }^{20}$ Nem depois de morto Marco Antônio voltou a Roma, visto ter sido enterrado em Alexandria.
} 
As ações de Marco Antônio nos possibilitam analisar nossa outra forma de se observar o mundo oriental. Tudo o que ele fazia fora de Roma poderia ser lido de diversos modos e tomado na mise en scène política de várias formas. Foi justamente o que Otaviano procurou fazer numa busca de sua própria autopromoção. Assim, observar Marco Antônio pelo plano mental do outro se faz importante dentro do contexto de disputa política dos triúnviros e de elaboração de discursos de ameaça e de defesa da República. As estadias de Marco Antônio em Alexandria são muito interessantes para analisarmos isso. O modo de viver do Oriente adotado em alguns hábitos de Marco Antônio foi alvo de críticas, sendo o estrangeiro, o outro, inferior e perigoso ao romano e à República.

A primeira das estadias de Marco Antônio no Oriente se deu entre 42 e 40 a.C.. Segundo Pelling, ele foi para o Oriente buscar restabelecer a dominação romana na região, que havia sido desestruturada pelo fato de as províncias da Macedônia e da Síria terem estado sob comando dos cesaricidas e esta última sofrer com a presença próxima do exército parto comandado por Labieno. Era uma tarefa difícil, mas recompensadora por permitir arrecadar os recursos para se empreender uma guerra contra os partos, o que traria um grande prestígio a Marco Antônio (PELLING, 2001, p.10-12). Este esteve na Grécia, na Ásia, em Éfeso e na Síria, tratando tanto de questões diplomáticas, quanto fazendo arrecadações, já que tinha como objetivo futuro empreender confrontos contra os partos. Contudo, como parte da cena política oriental, ele participou de cerimônias, jogos, e passou a se associar com Baco, o que faz com que Plutarco fale que ele levava uma vida menos virtuosa (PLUTARCO, Marco Antônio, 26-28). Devemos ressaltar que ainda aqui ele não se encontrava em Alexandria.

Foi nessa primeira estadia oriental que o triúnviro romano iniciou seu romance com Cleópatra. Pelling aponta que a relação entre os dois foi inicialmente diplomática, visto Marco Antônio também tratar de questões territoriais ou de outra natureza com reis das regiões fronteiriças com a Partia, como a Judéia e na Síria (PELLING, 2001, p.12), porém, são as cores realçadas do relato de Plutarco que permanecem no imaginário geral, com a chegada de Cleópatra em Tarso, em 41 a.C., num navio que exalava a perfume, com suas servas vestidas como Nereidas (PLUTARCO, Marco Antônio, 26). Mas o biógrafo não deixa de apontar que o triúnviro romano havia mandado convocar Cleópatra para uma reunião, como estava sendo efetuado com os demais governantes orientais, cabendo a ela a responsabilidade do uso de sua graciosidade como uma arma a seu favor (PLUTARCO, Marco Antônio, 25-26). 
Depois desse encontro inicial ${ }^{21}$, Marco Antônio foi com Cleópatra para o Egito. Tomando a narrativa de Plutarco para análise, é este o período em que observamos uma descrição de uma vida desregrada do triúnviro em Alexandria, com o elencar na narrativa de banquetes, diversões noturnas e, o principal dos acontecimentos, a criação do grupo 'os inimitáveis' (PLUTARCO, Marco Antônio, 28-29). Temos assim um breve período da vida de Marco Antônio, cerca de poucos meses entre 41 e 40 a.C., em que ele viveu um maior relaxamento de suas ações enquanto triúnviro, tanto que Plutarco afirma que a chegada das notícias de Roma, sobre a agitação de Perúsia, e da Síria, sobre as investidas de Labieno como comandante do exército parto, fez Marco Antônio por um fim ao seu sonho oriental (PLUTARCO, Marco Antônio, 30). Dion Cássio nos fala que ele não se encontrava alienado aos eventos relacionados à Fúlvia e a Labieno, porém, “[...] acorrentado pelo amor [de Cleópatra] e pela embriaguês, ele [Marco Antônio] não pensava nem em seus aliados, nem em seus inimigos" (DION CÁSSIO, História Romana, XLVIII, 27).

Entretanto, como os autores antigos nos mostram, apenas apontar que Marco Antônio era um homem degenerado devido à adoção de um comportamento social estrangeiro não era suficiente, visto a necessidade de tal absorção cultural para uma melhor aceitação no exterior e assim realizar suas obrigações enquanto triúnviro nas províncias orientais. Era necessário mostrar 'ao Senado e ao povo romano' que Marco Antônio havia 'quebrado' o seu 'pacto' com a Urbs em benefício pessoal ou de outrem, se mostrando não mais compromissado para com seus concidadãos e a República.

O que nos faz perceber isso é o próprio modo como os escritos antigos abordam a adoção de hábitos estrangeiros por Marco Antônio. Segundo Plutarco, a absorção de costumes estrangeiros, modos asiáticos como ele aponta, pelo triúnviro, se deu enquanto jovem quando foi aperfeiçoar seus estudos na Grécia. Assim sendo, desde a adolescência Marco Antônio possuía esses traços, como o modo de oratória, por exemplo, não cabendo à época de triúnviro ou a Cleópatra tal ensinamento e incentivo ao uso de hábitos estrangeiros (PLUTARCO, Marco Antônio, 2). Para Plutarco o amor de Cleópatra apenas aflorou males adormecidos e potencializou aqueles que Marco Antônio já possuía, sendo isto a causa de desgraças ao triúnviro romano (PLUTARCO, Marco Antônio, 25). Dion Cássio aponta tais costumes apenas após a viagem de Marco Antônio para o Oriente enquanto triúnviro, quando da

\footnotetext{
${ }^{21}$ Não podemos deixar de apontar que Marco Antônio e Cleópatra já se conheciam, visto ela ter sido hospedada por César em Roma entre 46 e 44 a.C.. No entanto, a ocasião era outra e, de acordo com Plutarco, "ela ia se encontrar com Marco Antônio justamente numa idade em que a beleza de uma mulher está em todo o seu esplendor e o espírito com toda força", por volta dos 27 anos de idade, mesmo que, de acordo com o próprio escritor, sua beleza não a diferenciasse das demais mulheres (PLUTARCO, Marco Antônio, 25).
} 
narrativa dos festins em comemoração a paz de Brindes, dizendo que "[...] eles [Marco Antônio e Otaviano] se deram reciprocamente um festim, César à maneira de um soldado e de um romano. Marco Antônio à maneira de um asiático e de um egípcio" (DION CÁSSIO, História Romana, XLVIII, 30).

Desse modo, não podemos apontar quando teria começado uma degeneração de Marco Antônio com a adoção de costumes externos, até porque os romanos já faziam trocas culturais de modo mais corrente com estrangeiros, não sendo apenas uma ou outra pessoa a estar em contato com elementos do tipo. No entanto, alguns elementos de sua conduta no exterior foram destacados e utilizados nesse processo de (des)construção de sua imagem.

Os poetas do século I a.C. tiveram uma forma peculiar de descrever Marco Antônio. Devido ao recente acontecimento dos eventos de Actium, o antigo rival de Otaviano/Augusto foi apresentado através das letras augustanas principalmente como esposo da rainha, ou seja, não havia uma caracterização dele enquanto um homem romano que havia tido um grande papel militar e político no passado. Marco Antônio é trazido de forma inferiorizada, sem que seu nome seja citado, apenas no caso de Virgílio, como um apêndice da principal rival romana, Cleópatra, de acordo com o discurso do romano vencedor.

Para Propércio, ele era o impudico esposo que abriria as portas de Roma para a dominação de Cleópatra (PROPÉRCIO, Elegias, III, 11, v.31). Numa das odes de Horácio ele é apresentado como alienado a uma mulher, a Cleópatra, e que a ela servia junto a eunucos, modo como são descritos os egípcios (HORÁCIO, Epodos, I, 9, v.11-13). Já em Virgílio, no fragmento da descrição dos escudos de Vulcano, temos Marco Antônio trazido nominalmente como opositor a Augusto e chefe de um exército composto por vários tipos de bárbaros, acompanhado de sua esposa, aqui quem não é citada pelo nome é Cleópatra (VIRGíLIO, Eneida, VIII, 680-683). Portanto, alguns dos autores da época augustana acabaram por se apropriar da imagem de Marco Antônio enquanto o esposo de Cleópatra, a qual eles desejavam desconstruir e, assim, acabavam arranhando também a imagem do antigo triúnviro romano, sendo a rainha usada como um modo de construir uma imagem mais inferiorizada do rival do então princeps senatus.

No entanto, mais do que apenas construir um retrato de Marco Antônio como um estrangeiro, através da explicitação de que ele havia se apropriado de costumes estrangeiros, era necessário mostrar que ele não agia mais em prol dos romanos. Essas duas facetas são importantes para comporem o quadro geral de demonstração de uma degeneração dos padrões civis romanos por parte do triúnviro. Desse modo, devemos então tratar de como alguns 
acontecimentos passaram a ser mobilizados no intuito de mostrar algumas atitudes de Marco Antônio para com os egípcios.

Plutarco nos narra alguns desses acontecimentos que são apresentados na tentativa de comprovar a falta de compromisso de Marco Antônio com a Urbs. O primeiro deles é o triunfo ocorrido em Alexandria em 34 a.C. após a captura de Artabaso, rei dos armênios, que havia se retirado juntamente com sua tropa do campo de batalha romano logo no início da guerra contra os partos. Ora, triunfos, além de ser uma grande honra para um homem da República romana, ocorriam apenas em Roma. Era ao povo romano que se deveria mostrar tal vitória e ser levado para Urbs o butim de guerra e o prisioneiro. Marco Antônio, no entanto, escolheu a capital egípcia para tal comemoração. Plutarco nos fala que essa atitude foi muito mal vista entre os romanos "porque ele causou grande pesar aos romanos, ao conceder aos alexandrinos, por causa de Cleópatra, um belo e nobre espetáculo que era um privilégio de sua pátria” (PLUTARCO, Marco Antônio, 50).

O segundo episódio apontado por Plutarco é a recusa de Marco Antônio ir a Atenas se encontrar com Otávia devido a uma expedição militar que ele estava preparando na região do Levante. De acordo com o biógrafo, o referido encontro foi premeditado por Otaviano, mesmo que atendendo a um pedido de sua irmã, para que assim ele conseguisse um pretexto para guerra contra seu rival (PLUTARCO, Marco Antônio, 53), o que nos mostra que o triunfo por si só, apesar de ter causado certo desconforto entre os romanos, não era um motivo para comprovar uma degeneração dos padrões civis de Marco Antônio. O uso de Otávia era muito significativo, pois os dois triúnviros estavam unidos através do laço matrimonial de Marco Antônio e Otávia, e qualquer atitude que viesse a ser tomada poderia simbolizar uma ação imprópria com ela, visto ser, ao menos de acordo com Plutarco, uma mulher tão bela, inteligente e bem estimada (PLUTARCO, Marco Antônio, 31). O que reforça isso é a própria ação de Cleópatra, de acordo com Plutarco, que se viu ameaçada por Otávia e passou a encenar mais fortemente o quanto amava Marco Antônio e o quanto sofria deste amor (PLUTARCO, Marco Antônio, 53). Os objetivos iniciais de Otaviano podem até ter sido alcançados com esse repúdio de Marco Antônio, porém, ainda não foi suficiente para uma guerra aberta entre eles.

O acontecimento seguinte, também em 34 a.C., foi outro episódio que teve lugar em Alexandria e foi muito mal visto pelos romanos, pois foi considerado, segundo Plutarco, como "uma manifestação teatral e arrogante de hostilidade contra Roma". São as conhecidas 'Doações de Alexandria', pelas quais Marco Antônio nomeava Cleópatra e Cesário reis do Egito, de Chipre, da Lídia e da baixa Síria. Quanto aos seus filhos com a rainha lágida, 
Alexandre e Ptolomeu, foram nomeados reis dos reis e como partilha deu ao primeiro a Armênia, a Média e a Partia, assim que essa tivesse sido subjugada por ele, e ao segundo deu a Fenícia, a Síria e a Cilícia, sendo Cleópatra a rainha de todas essas terras, parte das possessões orientais de Roma, já que seus filhos ainda eram muito jovens (PLUTARCO, Marco Antônio, 54). O biógrafo narra que Otaviano fez graves acusações no Senado e diante do povo contra Marco Antônio devido ao acontecido em Alexandria, o que foi respondido através de uma embaixada a Roma em que houve uma grande troca de acusações entre ambos por territórios, soldados e devido à exclusão de Lépido do Triunvirato (PLUTARCO, Marco Antônio, 55).

Para Dion Cássio, a narrativa desses eventos é um pouco diferente. O autor apresenta brevemente os referidos episódios de Alexandria, apontando que as doações se deram no contexto do próprio cortejo num estilo triunfal em que o butim da guerra contra a Armênia e o prisioneiro foram apresentados aos alexandrinos. O autor diz que Marco Antônio chegou a enviar cartas a Otaviano e ao Senado falando de suas ações em Alexandria, mas não observamos uma inserção desses acontecimentos na narrativa como um elemento crucial para a comprovação de uma degeneração de Marco Antônio, nem uma posição ofensiva de Otaviano (DION CÁSSIO, História Romana, XLIX, 40-41).

No entanto, o acontecimento mais importante dentre esses é a tomada do testamento de Marco Antônio, que se encontrava junto das Vestais em Roma, e a sua leitura perante o Senado. Como nos narra Plutarco "[...] ele [Otaviano] começou por percorrê-lo [o testamento], para si próprio, as disposições, marcando algumas que poderiam dar lugar a acusações" e leu para os senadores, sendo que, “[...] insistiu sobretudo nas disposições relativas à sepultura de Marco Antônio, que ordenava que, mesmo se ele morresse em Roma, seu corpo, após ser levado em cortejo através do Fórum, fosse enviado para Alexandria para perto de Cleópatra" (PLUTARCO, Marco Antônio, 58). Ora, o pedido para que fosse enterrado em Alexandria era uma afronta aos romanos, visto Marco Antônio abrir mão de sua cidade por outra. Suetônio também nos apresenta o testamento de Marco Antônio como o objeto que provava a degeneração do antigo triúnviro e a causa do rompimento entre ele e Otaviano, mas destaca o fato de seus filhos com a rainha serem considerados seus herdeiros (SUETÔNIO, Augusto, 17) ${ }^{22}$. Dion Cássio também nos mostra o testamento de Marco

\footnotetext{
${ }^{22}$ Augusto buscou mostrar seu compromisso com a Urbs até em sua morte e após ela. Como comprovação disso, temos o complexo de seu mausoléu, construído a partir de 28 a.C., no Campo de Marte em Roma. Nesse espaço foram depositadas as suas cinzas e de parentes e amigos, bem como também suas res gestae, a qual exaltava os seus feitos em prol 'da República e do povo romano'. Ora, enquanto Marco Antônio 'preferia' uma cidade do exterior, ele escolhia a Urbs.
} 
Antônio como um ponto importante para as críticas de Otaviano, no entanto, não podemos deixar de ressaltar que sua visão, assim como a dos autores anteriores, é muito posterior e põe Cleópatra como a razão de tudo, pois, de acordo com a sua narrativa, "os romanos se indignaram e acreditaram que todos os barulhos anteriores eram verdadeiros, sabendo que, se Marco Antônio morresse, ele daria de presente sua cidade a Cleópatra e colocaria no Egito o centro do poder" (DION CÁSSIO, História Romana, L, 3-4).

Desse modo, a auctoritas de Marco Antônio, que já havia sido abalada com a derrota romana perante os partos, aos poucos foi sendo diminuída. Mesmo assim, apenas, o testamento do antigo triúnviro foi o elemento que serviu como prova de uma predileção de Alexandria em detrimento de Roma. Como apontado, os triúnviros tinham entre si um compromisso para com a República romana buscando que ela se consolidasse, porém, essa ação testamentária de Marco Antônio acabou por fornecer a Otaviano o motivo para a guerra que ele precisava, pois seu rival pôde ser considerado inimigo público e a guerra declarada a Cleópatra $^{23}$. No entanto, apesar disso, Marco Antônio ainda possuía junto a si um grande número de partidários, inclusive homens das mais altas magistraturas. Ou seja, nem mesmo o testamento serviu como uma prova irrefutável de degeneração civil, talvez fosse apenas aquilo de que Otaviano precisava para confirmar suas acusações de que Cleópatra estava mais poderosa do que deveria estar e que Marco Antônio já não agia mais apenas em prol da República.

O próprio Augusto nos fornece informações que comprovam isso quando ele diz em suas res gestae, "a Itália inteira fez, espontaneamente, um juramento de lealdade a mim e exigiu-me comandante da guerra que venci em Actium" (Res Gestae, V, 25). O juramento realizado por todos os italianos ${ }^{24}$, em 32 a.C., teve o intuito de fomentar uma legitimidade para suas ações antes da batalha do Actium. Aqui temos a explicitação do apoio a ele dado e mais do que isso, o selar de um compromisso, visto que era a ele que os romanos estavam escolhendo na luta entre os triúnviros. Era uma espécie de aceite de sua proposta para a restauração da República que teria como lema o seguimento dos moldes dos antepassados, através do respeito ao mos maiorum romano, ao invés da tentativa de transformação da República em algum tipo de governo fora da égide 'do Senado e do povo romano', como se atribuía a Marco Antônio. Entretanto, esse juramento é mais um dos elementos que vem a

\footnotetext{
${ }^{23}$ De acordo com Dion Cássio: "Essas medidas [a declaração da guerra realizada por Otaviano enquanto fecial] visavam oficialmente Cleópatra, mas foram de fato dirigidas a Marco Antônio" (DION CÁSSIO, História Romana, L, 4).

${ }^{24}$ Exceto os bolonheses, que foram excluídos de tal obrigatoriedade, por serem, havia séculos, clientes dos Antonii (SUETÔNIO, Augusto, 17).
} 
somar para visualizarmos a posição frágil de Otaviano, que dependia de um juramento de lealdade para que sua ação fosse legitimada, o que nos mostra como a ameaça de Marco Antônio não seria tanto eminente e unanimemente aceita.

Após ser lido o testamento de Marco Antônio, se iniciou a preparação para o confronto entre os dois antigos triúnviros, o qual ocorreu em Actium, na costa grega, em 31 a.C.. A batalha travada no mar foi vencida por Otaviano após a fuga de Marco Antônio ao seguir as naus da rainha egípcia. Plutarco e Dion Cássio nos dedicam muitas linhas para tratar dos eventos posteriores a batalha, sobretudo nas relações travadas até a morte dos amantes e a conquista de Alexandria e do Egito (DION CÁSSIO, História Romana, L, 31-35; LI, 1-17; PLUTARCO, Marco Antônio, 60-86). No entanto, quem nos traz importantes elementos analíticos é Dion Cássio.

O autor, no livro 50 de sua 'História Romana', ao narrar essa fase de preparação para Actium, traz o que teriam sido os discursos dos triúnviros às suas tropas antes do confronto, nos quais eles defendiam suas razões para guerra e faziam acusações entre eles. Sabemos que tais discursos são construções, são palavras colocadas nas bocas de Marco Antônio e Otaviano por Dion Cássio, e, dessa forma, não devem ser encarados como verdadeiros. Contudo, eles são interessantes no intuito de se buscar trazer uma memória mais positiva de Marco Antônio, apresentando que ele também tinha motivos para querer a guerra contra Otaviano e que muitos, como é o caso de seus partidários, compartilhavam daqueles mesmos pensamentos e projetos para o futuro de Roma. É uma forma de visualizarmos possíveis ecos de memórias dentro da própria Antiguidade (DION CÁSSIO, História Romana, L, 16-30). A própria forma indireta das acusações, através das palavras de Otaviano, o que nos lembra os discursos entre Cícero e Caleno na fase das 'Filípicas', parece ser uma forma do próprio autor se isentar de acusar diretamente Marco Antônio e trazer outros elementos além do discurso do vencedor para análise.

No que concerne a esses discursos, Freyburger e Roddaz, tradutores da edição francesa da Belles Lettres, começam apontando o espaço privilegiado legado a eles no interior do livro 50 de Dion Cássio, em que dos 35 parágrafos que compõem o livro, 15 são referentes às falas dos rivais. Os autores argumentam, que apesar da inexistência de provas concretas da existência desses discursos, os quais, por exemplo, não são citados por Plutarco em sua biografia sobre Marco Antônio, não devemos apenas apontá-los como construções fictícias no interior da narrativa de Dion Cássio, pois os antigos, inclusive Otaviano, tinham o hábito de redigirem esses discursos, as hortationes, para que posteriormente fossem lidos diante dos romanos na própria Urbs. O que os faz crer que, apesar de não serem literais, não são 
completamente falsos, visto no interior das palavras do autor estarem presentes muitos dos ecos do que seriam as linhas gerais de algumas das acusações trocadas entre Otaviano e Marco Antônio na época pré ou logo posterior a Actium (FREYBURGER; RODDAZ, 1991, p.26-27; 31).

O discurso atribuído a Marco Antônio (parágrafos 16 ao 22) é bem simples, composto por dois blocos temáticos, o de exaltação de si próprio e de seu exército e o de críticas ao opositor, Otaviano. Quanto ao primeiro ponto, Marco Antônio exalta seu exército, que seria composto por romanos e estrangeiros (aliados e submetidos), como temido pelos adversários e também aborda suas próprias características militares como a maturidade física e intelectual, a educação recebida e a experiência anteriormente adquirida em assuntos militares e políticos (DION CÁSSIO, História Romana, L, 16-17). Desse modo, temos Marco Antônio, através de Dion Cássio, sendo apresentado de maneira positiva, reforçando que ele tinha uma trajetória e capacidades para agir pelo bem da República, algo que Dion Cássio também insere no discurso de Marco Antônio quando ele se apresenta aos seus soldados como um defensor da libertas, um tema tão caro aos senadores do império (DION CÁSSIO, História Romana, L, 22).

No que diz respeito às críticas a Otaviano, diversos elementos são elencados, como: a fragilidade do exército do rival, composto com recursos pouco abundantes e advindos de doações forçadas; a juventude e a inexperiência de Otaviano (o chefe militar do exército rival), que não havia obtido nenhuma vitória significativa, sendo a conquista contra Sexto Pompeu menosprezada; a responsabilidade pela exclusão de Lépido da magistratura de triúnviro sem que este houvesse dado razão para tal (DION CÁSSIO, História Romana, L, $16 ; 18-20)$. Este último ponto que é o central com relação às críticas a conduta de Otaviano. Como Freyburger e Roddaz argumentam, o comportamento moral de Otaviano não é trazido no bojo das críticas que teriam sido proferidas por Marco Antônio ao rival diante de seu exército, de acordo com o que Dion Cássio nos traz (FREYBURGER; RODDAZ, 1991, p.28). Ora, como visto anteriormente, Suetônio mostra alguns episódios criticados por Marco Antônio com relação à conduta moral e social de seu opositor, os quais poderiam estar no texto que Dion Cássio construiu. O que o historiador romano nos apresenta como razões para se combater Otaviano além da exclusão de Lépido seriam as injustiças cometidas contra Marco Antônio, como privações (ele havia se tornado um simples cidadão, sendo destituído de suas funções públicas), as invasões (como a tomada de seu testamento para leitura) e acusações. Tudo isso devido às vontades de Otaviano, o qual é acusado de ser uma ameaça 
aos romanos e desejar apenas dominá-los (DION CÁSSIO, História Romana, L, 20-22), contrariando seu discurso de protetor de seu povo.

O discurso de Otaviano com relação a Marco Antônio é muito interessante. Freyburger e Roddaz apontam que duas temáticas específicas se encontram no interior das palavras atribuídas a Otaviano: 1) a explicitação da legitimidade de sua luta (parágrafos 24 ao 27) e 2) a demonstração de que o inimigo não era invencível (parágrafos 28 ao 30) (FREYBURGER; RODDAZ, 1991, p.29). Com relação ao primeiro tópico, o jovem romano aborda críticas tanto a Marco Antônio, quanto a Cleópatra conjuntamente, se utilizando de acusações aos dois para se colocar como promovedor de uma guerra justa. Dion Cássio apresenta um Otaviano que buscava legitimar suas ações, se colocando como um homem que agia segundo as leis humanas e divinas e era contrário à subjugação das conquistas e da grandiosidade dos romanos à dominação de uma mulher egípcia, modo como Cleópatra é denominada (DION CÁSSIO, História Romana, L, 24). A tônica central do que teria sido o discurso é justificar as ações bélicas de Otaviano, que havia fomentado e executado, enquanto fecial, a declaração de guerra a Cleópatra e ao rival.

Para o presente capítulo, os dois pólos de acusação aos rivais serão separados para que apenas o que diz respeito diretamente ao rival romano seja analisado. Otaviano ao se colocar como defensor do mundo romano apresenta Marco Antônio enquanto opositor a este e nesse processo (des)constrói a imagem do rival: 1) através de acusações de que ele estava adotando hábitos egípcios; 2) através da apresentação de Cleópatra como a causa de muitos males ao triúnviro.

Caracterizar Marco Antônio enquanto um estrangeiro, a partir da adoção de costumes da região oriental do Mediterrâneo, trazidos como estrangeiros e bárbaros (DION CÁSSIO, História Romana, L, 25), principalmente egípcios, como apresentado anteriormente, era uma artimanha importante para que Otaviano se colocasse como o único a agir em prol dos romanos, sem uma ameaça à República. E o discurso construído por Dion Cássio e atribuído a Otaviano, tem como elemento central justamente essa apresentação de Marco Antônio enquanto um estrangeiro, ou seja, um não-romano. Diversos são os meios para a construção dessa oposição entre eles. Podemos perceber através do texto do historiador romano como muitos ecos do que teria sido veiculado nas décadas de 30 e 20 a.C., sobretudo por meio de cartas privadas, como algumas que Suetônio se utilizou para a composição de sua biografia sobre Augusto. O que nos mostra como tais construções na época dos eventos foram importantes. 
Marco Antônio é trazido às palavras de Otaviano como um homem que tinha uma vida luxuriosa em Alexandria, se dedicando a ações no ginásio, o que o afastava dos modos romanos, tanto que a guerra contra os partos foi perdida justamente, como presente nos discursos, pela pouca prática militar que o triúnviro romano estava exercendo no Oriente. Ele também é apresentado como um tocador de címbalo de Canopo e acusado de ter adotado a denominação de Serapião, nome que remetia a uma possível associação ao deus egípcio Serapis. As críticas, no entanto, não se dirigiram apenas a Marco Antônio, mas também a todos os seus partidários, amigos e a sua força militar, que, de certo modo, compartilhavam de suas ações e se constituíam em um bloco opositor àquilo que Otaviano se dizia defensor (DION CÁSSIO, História Romana, L, 27). Marco Antônio também é acusado de descaso com as leis e os deuses e com o povo romano, tendo adotado nomes como Dionísio e Osíris e tratado Cleópatra como se ela fosse uma deusa, bem como realizado doações de terras pertencentes aos romanos aos egípcios (DION CÁSSIO, História Romana, L, 25).

O discurso de Otaviano construído pelo historiador aborda uma oposição entre romanos e egípcios com o menosprezo dos costumes desses últimos, sendo elencados a crença na imortalidade e o culto de deuses animais, como répteis, por exemplo; e como a adoção de hábitos deles, bem como ação em prol dos egípcios, servia como um modo de descaracterizar os apoiadores de Marco Antônio, sejam os senadores e cavaleiros que são associados a eunucos por possuírem hábitos estrangeiros, sejam os soldados por comporem a guarda da rainha. Cleópatra também é considerada como um elemento nefasto de seu povo, pois ela era naturalmente inimiga romana por ser estrangeira, mas sua dominação sobre os egípcios, que serviam a uma mulher, não a um homem, era o ponto central que reforçava a inferioridade dos egípcios e, consequentemente, dos romanos que a eles se associavam (DION CÁSSIO, História Romana, L, 24-25).

Contudo, a razão principal para a ruptura entre os aliados não foi a degeneração de Marco Antônio, o repúdio de Otávia ou o amor que ele detinha por Cleópatra, mas as ações que ele apresentou após a declaração de guerra à rainha, sendo ele o responsável por tomar o partido contrário a sua pátria e se tornado um inimigo romano (DION CÁSSIO, História Romana, L, 26). O modo como Dion Cássio traz isso ao discurso de Otaviano é interessante, pois é mais uma artimanha retórica de legitimação das atitudes pré-guerra do acusador. Assim, mais do que apresentar más ações e adoções de costumes diferentes, o que o Otaviano de Dion Cássio faz é colocar toda a responsabilidade do rompimento dos laços entre ele e Marco Antônio neste próprio, o que, porém, não observamos em textos de outros autores antigos, como, por exemplo, Suetônio e Plutarco. 
Em comparação, os discursos trazidos por Dion Cássio, que não devem ser tomados como elementos verdadeiros, mas que também não devem ser totalmente desconsiderados, nos trazem alguns ecos do que teriam sido as temáticas de acusações entre os dois rivais e difundidos no interior de seus grupos partidários ou aliados. Cada um procurava se apresentar como um bem à República e como possuidor de um projeto de futuro para os romanos, diferentemente do que era apresentado pelo opositor. No entanto, as ações dos homens no passado nos legaram apenas uma das vertentes discursivas, a do vencedor, Otaviano. Contudo, não devemos deixar de apontar que nenhum dos dois era visto de modo unânime, tendo de saber se colocar na cena política romana, porém, apenas a ação de Otaviano é a que conhecemos.

Apesar de Otaviano ser tomado como o principal vetor de críticas a Marco Antônio, devemos fazer uma ressalva importante tomando o documento das res gestae de Otaviano. Nesse documento, observamos apenas duas passagens em que há alusão a ele. No texto como um todo, os rivais nunca são referenciados nominalmente, sendo tal alusão elaborada de modo indireto, em que Augusto se engrandece a partir desses pontos discursivos. A primeira delas é logo na abertura do documento quando Augusto diz ter formado um exército particular e com ele libertado a República da opressão de uma facção (Res Gestae, I, 1). Como já apontado anteriormente, essa facção era a de Marco Antônio e que foi vencida na batalha de Módena, em 43 a.C.. Desse modo, o texto se abre já apontando a oposição existente entre os dois, pois em nenhum momento Marco Antônio é citado como um homem que fez algum bem à República e uma apresentação dele, mesmo que sem citação direta ao seu nome, como um 'mal' à República desde o princípio, acaba por reforçar os bons atos daquele que o venceu militarmente.

Já a segunda referência é quando o príncipe discorre sobre seus feitos com relação às províncias orientais. Augusto fala que devolveu os ornamentos aos templos asiáticos, quando vencedor, visto que, segundo ele, "aquele com o qual eu guerreara havia espoliado esses templos e usado dos ornamentos como sua propriedade particular" (Res Gestae, IV, 24), ou seja, durante o período em que Marco Antônio esteve no governo das províncias orientais em concordância com o acordo Triunvirato. Através dessa alusão, o príncipe busca mostrar aos leitores de suas res gestae que ele havia agido de modo diferente de seu rival, não se apossando indevidamente de nenhum tesouro das províncias, muito pelo contrário.

Contudo, o que mais nos interessa é a ausência de qualquer referência a Marco Antônio enquanto um homem que não desejava efetuar uma restauração da República, apesar do cargo de triúnviro, através da implementação de um sistema político monárquico, ou que 
possuísse algum traço de degeneração dos costumes civis, os quais poderiam ter sido aproveitados por Augusto numa crítica mais direta em suas palavras. O que vemos de referência direta é "aquele com o qual eu guerreara" (Res Gestae, IV, 24), o que reforça o confronto bélico entre os dois triúnviros, mas apenas isso. Observamos a construção discursiva da auto-promoção de Augusto sobre seu rival que é considerado nefasto à República, o que se justifica, possivelmente, pelo objetivo do documento, o engrandecimento dos feitos de Augusto, sem ataques diretos àquele com o qual agiu no cenário político romano. Cleópatra também não é nem alvo das palavras de Augusto, só há nas res gestae uma breve explicitação, embora muito simbólica, da conquista do Egito: "anexei o Egito ao império do povo romano" (Res Gestae, V, 27).

Também não podemos deixar de apontar para as exclusões existentes no interior do texto de Augusto, o que não diz respeito apenas a Marco Antônio. Devido à própria natureza das res gestae, que seria o engrandecimento do personagem principal do conjunto do mausoléu e a celebração de seus feitos enquanto um homem político, não observamos a busca em mostrar quem ajudou Augusto em sua ação virtuosa em prol 'do Senado e do povo de Roma'. Agripa não é citado enquanto um homem que promoveu bem-feitorias para a sociedade romana ou que lutou muitas vezes ao lado de Augusto, o mesmo acontece com Marco Antônio que não recebe os créditos por sua vitória militar em Filipos (Cf: Res Gestae, I, 2).

Desse modo, o texto epigráfico das res gestae, um dos principais expoentes do discurso augustano, não foi um espaço utilizado para se fazer ataques aos rivais. Com isso, temos aqui um dos exemplos, o que também pode ser observado dentro do discurso arquitetônico da Urbs, de que o ataque a Marco Antônio e a Cleópatra, com o passar dos anos e a partir de uma maior estabilidade da posição de Augusto no cenário político romano, deixou de ser importante e direto. Podemos até interpretar isso como uma damnatio memoriae indireta, pois não se lembrar desses episódios, nem para se construir a oposição entre eles, é um modo de esquecer um passado que pode ter sido mais manipulado do que real, o que viria a gerar insatisfações de alguns antigos partidários. Um esquecimento intencional que diz muito de outra época em que Augusto se encontrava em sua teatrocracia política.

Apesar das críticas levantadas contra Marco Antônio, devemos trazer mais elementos à análise. Para isso nos utilizaremos da numismática. Tomemos duas peças monetárias cunhadas por Marco Antônio e Cleópatra. A escolha por elas se deve, primeiramente, pelo fato de a efígie do casal estampar o anverso e o reverso, o que nos mostra que os dois 
cunharam moedas conjuntamente. E, segundo, buscamos ver como cada um deles é retratado, o que é muito importante para a análise de discursos.
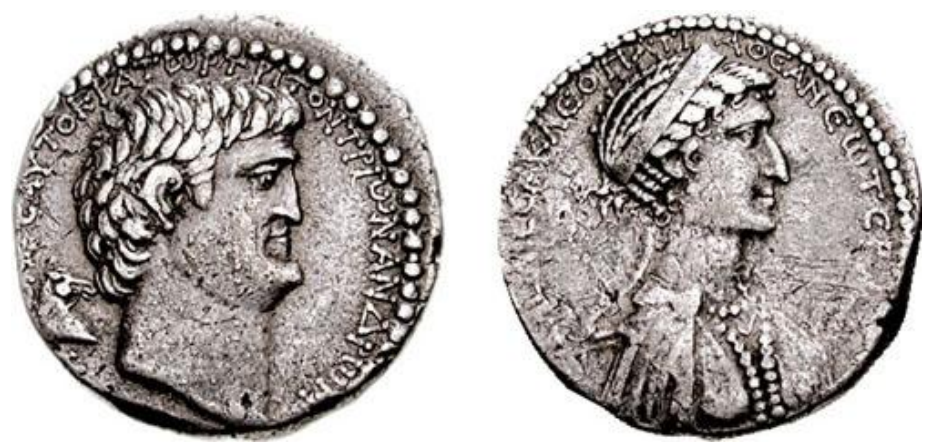

$\underline{\text { Imagem }} 4$ - Moeda de Marco Antônio e Cleópatra (RPC 4095); - tetradraquima de bronze (possivelmente Antioquia); - cunhada em 36-33 a.C.;

- Anverso: BACI L ICCA KLEOPATRA QEA NEWPTA - busto de Cleópatra portando o diadema e um colar de pérolas;

- Reverso: ANTWNIOC AUTOKRATWR TRITON TRIWN ANDRWN - busto de Marco Antônio com cabeça nua e um cavalo atrás;
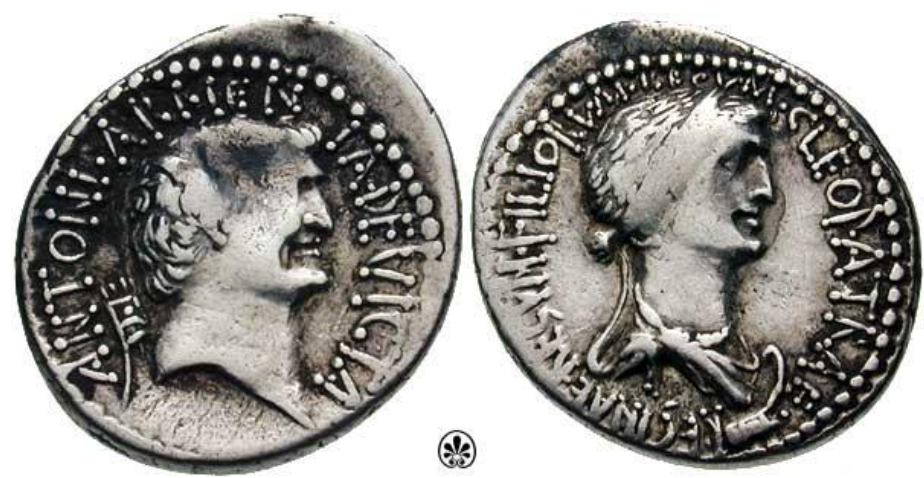

$\underline{\text { Imagem }} \underline{5}$ - Moeda de Cleópatra e Marco Antônio em homenagem a conquista da Armênia (RSC 1- Syd 1210); - denário de prata (Alexandria); - cunhada em 34 a.C.;

- Anverso: CLEOPATRAE REGINAE REGUM FILIORUM REGUM - busto de Cleópatra drapeado e com diadema - proa à frente;

- Reverso: ANTONI ARMÊNIA DEVICTA - busto de Marco Antônio de cabeça nua - tiara armênia atrás;

A análise dessas moedas cunhadas por Cleópatra e Marco Antônio é muito importante para observarmos como o próprio triúnviro também procurou se apresentar à sociedade romana através das peças numismáticas. Schwentzel afirma que mesmo que Marco Antônio possa ter assumido algumas características de monarca, o mesmo não o fez com os símbolos de poder, visto que ele não atribuiu a si o título de rei nem se retrata portando o diadema, o que se choca com a visão de orientalização do triúnviro romano espalhada por Otaviano 
(SCHWENTZEL, 2009, p.78-81). A representação de Marco Antônio é semelhante àquela presente nas peças romanas, como cunhadas juntamente com Otaviano. Em nenhuma das representações que possuímos dele, há uma associação com referenciais egípcios, como se acusava ao triúnviro de ter adotado.

No entanto, Cleópatra se apresenta com traços monárquicos, como o diadema, comum em suas representações. Até mesmo na segunda peça monetária (Imagem 5), cunhada em homenagem à conquista da Armênia, após o fracasso de Marco Antônio na Partia, não observamos uma associação do triúnviro com algum elemento monárquico. Na verdade, nos parece mais uma peça numismática que representa parceiros de guerra. Não vemos aqui também nenhum engrandecimento do Egito em oposição a Roma.

Zanker aponta que Marco Antônio não se preocupava tanto com a sua auto-imagem, tanto que buscou fazer associações religiosas que mais se aproximassem de sua natureza, como é o caso de sua associação com o deus Baco (ZANKER, 1988, p.57). Entretanto, não devemos pensar que ele fosse suficientemente ingênuo e não soubesse o poder que as imagens tinham. Seu comportamento social poderia não se adequar completamente ao esperado em Roma, mas ele não deixava transparecer isso através de suas representações. A análise monetária pode apontar para esse ponto, mas também não podemos deixar de pensar que essa não fosse uma opção consciente de Marco Antônio, que buscava não dar motivos concretos para ser criticado em Roma e ser visto como um inimigo ‘do Senado e do povo romano'. Não podemos fazer maiores afirmações quanto às imagens de Marco Antônio, pois pouco possuímos de suas imagens, visto ele ter sofrido a damnatio memoriae, sendo muitas delas destruídas após a sua morte, como nos aponta Plutarco (Marco Antônio, 86).

As fontes pouco nos apontam sobre quais seriam as intenções de restauração da República por Marco Antônio. Dion Cássio, que busca dar voz a este triúnviro através dos discursos às tropas pré-Actium, é um dos poucos que empreende um trabalho de dar voz ao vencido. $\mathrm{O}$ contexto desta afirmação é outro, é o das movimentações anteriores à batalha de Filipos, mas suas palavras cabem também para a relação entre Marco Antônio e Otaviano: "Alguns, porque vencem, passam por pessoas sensatas e bons cidadãos; os outros, porque são derrotados, recebem os nomes de inimigos da pátria e de homens execráveis" (DION CÁSSIO, História Romana, XLVI, 34). No entanto, além das próprias moedas de Marco Antônio, nas quais vemos a ausência de traços monárquicos ou de um não comprometimento com a Urbs, também temos uma breve passagem de Suetônio quando ele narra os momentos em que Augusto pensou em deixar a cena política. O primeiro desses momentos se deveu justamente a Marco Antônio quando ele fez acusações de que Otaviano era um empecilho a 
sua forma de restaurar a República, o que provocou um descontentamento em seu rival (SUETÔNIO, Augusto, 28). Com essas palavras de Suetônio, podemos visualizar como ambos se acusavam e como cada um tinha uma proposta para a República, mesmo que não saibamos de forma plenamente confiável qual era a de Marco Antônio.

$$
* * *
$$

Portanto, de modo geral, observamos como Otaviano se encontrava ainda numa posição frágil nos eventos anteriores e subsequentes a Actium e como a construção do retrato nefasto de Marco Antônio era delicado. O futuro príncipe romano precisou agir com sabedoria na cena política romana para poder se legitimar sem parecer um corpo estranho à República. A própria forma como essa dinâmica difamatória foi construída diz muito a respeito da época e do modo de se jogar o jogo político. As incertezas da atuação política sempre existiram. Macróbio, um autor do século IV d.C., através de uma breve anedota nos mostra isso.

\footnotetext{
"Quando ele [Otaviano] estava retornando a Roma no topo do mundo após sua vitória em Actium, um dos que correram para felicitá-lo estava segurando um corvo que ele treinou para dizer: 'Ave César, vitorioso comandante'. Maravilhado com o obediente pássaro, César o comprou por 20.000 sestércios. O parceiro do treinador, que não havia ganhado nada daquele ato generoso, jurou a César que aquele homem tinha outro corvo também, e César pediu para fosse mostrado. Quando o corvo foi trazido, ele falou as palavras que haviam sido ensinadas: 'Ave Antônio, o vitorioso comandante' [...]". (MACRÓBIO, Saturnais, II, 4.29).
}

Ora, Marco Antônio também possuía grandes apoiadores em Roma. Assim, coube a Otaviano montar seu personagem se baseando em seus feitos em prol 'do Senado e do povo de Roma', mostrando que ele era o melhor a ser seguido. Ele tinha que mostrar o que ele estava fazendo pela República. Desse modo, não podemos deixar de retomar o fragmento de Suetônio (Augusto, 17) e relembrar os dois pontos destacados pelo autor com relação ao rompimento entre Otaviano e Marco Antônio: a relação incerta existente entre eles e a busca pela comprovação da degeneração dos padrões civis por este último.

Os anos de Triunvirato foram importantes para a cristalização da posição de Otaviano na cena política romana. A criação de um discurso de oposição entre eles, enquanto Otaviano se apresentava como benéfico à República e Marco Antônio apontado como nefasto devido às suas ações no Oriente e ao seu comportamento perante a rainha egípcia, está na base da compreensão do modo de estabelecimento do Principado e da mise en scène do príncipe. A conturbada relação existente entre eles, desde o momento posterior à morte de César, agravada por Módena e Perúsia, mas restabelecida através de acordos como o do Triunvirato e 
a paz de Brindes, é significativa nesse quadro político romano, pois o Triunvirato e o Principado estão intimamente interligados, e no qual os dois disputaram a predileção entre os romanos no intuito de se mostrarem cada um como o mais compromissado com a Urbs e, assim, executarem a restituição da República. A troca de acusações entre eles, como visto pelas cartas trazidas por Suetônio ou os discursos que Dion Cássio constrói e atribui aos dois triúnviros no momento das preparações para Actium, demonstra como as relações foram complexas e inseridas na encenação política romana.

As acusações de degeneração direcionadas a Marco Antônio, sobretudo após a sua derrota contra os partos, em 36 a.C., se inserem nesse cenário de instabilidade e desequilíbrio nas relações entre Otaviano e Marco Antônio. A tônica desse período se diferenciou daquela trazida pelas palavras de Cícero nos discursos das 'Filípicas' em que Marco Antônio é caracterizado como um cônsul nefasto e uma ameaça tirânica aos romanos. Na segunda metade do Triunvirato, o que passou a ser mobilizado foi o comportamento social de Marco Antônio no Oriente, onde estava em cumprimento das atribuições dentro do acordo do Triunvirato para o restabelecimento das bases de dominação dos romanos na região posteriormente aos eventos de Filipos, em 42 a.C.. Assim, alguns elementos passaram a ser utilizados pelos romanos partidários de Otaviano para caracterizar o seu rival, como, por exemplo, o gosto que Marco Antônio tinha por banquetes, álcool e luxo, caracterizando sua estadia, principalmente em Alexandria, como um relaxamento dos comportamentos esperados de um magistrado romano; sua associação com o deus Baco; e, até mesmo, a adoção de costumes e hábitos egípcios, como o culto aos deuses deles. Desse modo, Marco Antônio passou a ser apresentado como um romano que fugia ao mos maiorum, o qual deveria ser seguido na mise en scène política entre os romanos.

Essa visão dele como um estrangeiro foi reforçada, como veremos, com o amor de Cleópatra, tanto que alguns autores antigos o trataram apenas como o esposo da egípcia. É nesse contexto que observamos o elencar dos acontecimentos do ano de 34 (o triunfo em Alexandria e as doações de Alexandria) e 32 a.C. (a leitura do testamento de Marco Antônio por Otaviano), pois, mais que apenas caracterizar Marco Antônio como um estrangeiro, era preciso mostrar que ele não mais agia apenas em prol da República romana, mas de sua esposa, a verdadeira inimiga de Roma, segundo o discurso de Otaviano. Foi com esse discurso que a guerra foi declarada e a encenação política construída, mesmo que anos depois, em suas res gestae, Augusto não toque nas querelas entre ele e Marco Antônio e Cleópatra ao relembrar seus feitos em prol 'do Senado e do povo romano'. 


\section{AUGUSTO E A 'AMEACA DA REALEZA'}

“Agora é beber, com o pé livre

o chão deve ser batido, agora

o tempo é de ornarmos os coxins dos deuses

com iguarias sálias, amigos.

Antes era ilícito tirar o Cécuba

das adegas ancestrais, enquanto para o Capitólio

uma rainha, dementes ruínas,

e, para o Império, o funeral preparava

Com um bando de homens repulsivos

contaminados por doença. Louca o suficiente

para esperar por qualquer coisa, e pela doce fortuna

embriagada. Mas reduziu o seu delírio

Uma só nau salva das chamas

e a mente alucinada pelo Mareótico

reduziu a verdadeiro temores

César, voando longe da Itália,

À força de remos, como o falcão persegue as tenras pombas ou como a lebre, acossada pelo rápido caçador, nos campos nevados de Hemônia, para que rendesse em correntes

O monstro fatal. Mas ela, um modo mais nobre de perecer buscou, nem femininamente a espada a amedrontou, nem ocultas praias por uma armada veloz tomou às escondidas.

Sua cidade tomada ousou encarar com expressão serena, vigorosa manuseou serpentes severa, para que entrasse no corpo o negro veneno.

Mais selvagem por causa da morte planejada recusando-se, como uma pessoa privada, ser certamente carregada pelas Liburnas cruéis não como uma humilde mulher ao triunfo soberbo" (HORÁCIO, Odes, I, 37).

O excerto acima apresentado é uma das odes de Horácio datada de aproximadamente 30 a.C.. Suas palavras nos apresentam um temor da dominação estrangeira em Roma, com a 
tomada do Capitólio, um dos principais espaços de poder romano. O poeta traz um retrato nefasto da inimiga da Urbs na época, a rainha egípcia Cleópatra VII, em oposição ao salvador de Roma, o jovem César, Otaviano, que é associado a um gavião responsável por acorrentar o monstro fatal, como é descrita a adversária.

Este texto de Horácio é um dos exemplos que possuímos de ataque à rainha egípcia através da elaboração de uma comparação entre ela e Otaviano. São poucos os exemplos que nos chegaram de escritos que buscaram fazer uma relação de oposição entre Otaviano e seus antigos rivais. A maioria dos textos procura fazer sempre um retrato positivo de Otaviano sem estabelecer uma oposição direta dele em relação a qualquer outra pessoa. No entanto, essa associação a Cleópatra, de forma inversa, como um defensor e bem-feitor para a Urbs, era muito importante para a legitimação de sua ação contra seu rival e antigo aliado de Triunvirato, Marco Antônio, e para o fortalecimento de sua própria frágil posição perante a sociedade romana.

Nosso foco, no presente capítulo, é buscar entender como se deu essa oposição entre Otaviano e Cleópatra, tentando entender as razões que levaram os romanos a temerem uma possível ameaça de dominação estrangeira, representada pela rainha egípcia, e compreender como esse discurso de perigo foi construído e articulado. Ele era multifacetado e dizia respeito não somente à rainha, mas ao casal em conjunto, pois torná-la nefasta fazia com que a auctoritas de Marco Antônio também fosse abalada. O discurso de Otaviano era o de defesa da República, algo inerente ao seu cargo de triúnviro e príncipe, e, no interior desse, a (des)construção de seus rivais foi um importante artifício na sua disputa política.

A rainha deve ser encarada como uma mulher que conhecemos através de um discurso político consciente, pois desvalorizá-la era importante para se atacar Marco Antônio. Mostrar que ela era uma ameaça política, que possuía uma vida desregrada, voluptuosa e antagônica em relação aos romanos e que seu amor por Marco Antônio e, principalmente, que o dele por ela era a razão de sua degeneração com relação aos mores romanos devem ser tomados como essenciais para a mise en scène de Otaviano/Augusto. Ele se fortaleceu e construiu sua posição de bem-feitor e defensor dos romanos através da busca pela demonstração de que seu rival era um fraco e que uma das razões disso era Cleópatra. Não podemos deixar de lembrar que foi contra ela que se declarou a guerra vencida na batalha de Actium, em 31 a.C.. Portanto, a rainha deve ser vista como uma das peças do quebra-cabeça discursivo de Otaviano em sua ação em prol da República. Desse modo, o presente poema de Horácio é um dos principais expoentes desse discurso em sua época e traz em suas linhas importantes elementos dessa fase de legitimação da ação política de Otaviano/Augusto na cena romana. 
Antes de uma análise mais detalhada sobre os elementos do texto do poeta romano, devemos observar o processo discursivo em que a escrita dessa ode se insere para que possamos, posteriormente, analisar essa imagem de ameaça do monstro fatal à República romana. Contudo, dois são os movimentos de (des)construção do retrato de Cleópatra. O primeiro deles nas décadas posteriores a batalha de Actium e durante a fase de estabelecimento do Principado e de atuação do príncipe na cena política romana; o segundo, pelos escritores posteriores ao principado de Augusto. Enquanto, inicialmente, observamos o objetivo de se justificar as ações de Otaviano durante o Triunvirato e as causas da deflagração da guerra entre os triúnviros, trazendo uma oposição entre romanos e egípcios, posteriormente, quando da construção das narrativas sobre o período, notamos uma mudança no enfoque, não sendo mais uma visão estereotipada da rainha o foco, mas as atitudes tomadas durante a década de 30 a.C. trazidas para ilustrar a degeneração de Marco Antônio devido ao seu amor por Cleópatra.

\section{Entre romanos $\mathrm{e}$ estrangeiros, alteridade e identidade:}

Nos encontros culturais, como aponta Burke, em que o eu analisa e traduz o outro, duas formas de leitura são possíveis, uma mais positiva, em que há o destaque das semelhanças através do uso de analogias, e outra mais negativa, em que as diferenças, com o uso de antíteses, são reforçadas. A maioria dessas leituras do outro é um estereótipo, sempre parcial e exagerado, porém, não falso. Essa visão do outro é homogênea, ou seja, não plural, e quase sempre baseada no segundo modo de leitura, o negativo, com o destaque do exótico e do que é distante, sendo, na verdade, a inversão da auto-imagem. Caracterizando essa inversão do $e u$ dada através da construção de uma imagem mental do outro (BURKE, 2004, p.153-174).

Segundo Hartog, essa relação com o outro se baseia numa retórica da alteridade ${ }^{25} \mathrm{em}$ que há uma tradução/construção do outro para o nós, visando transportar o outro àqueles que terão contato com os relatos ou mesmo com aquelas imagens, pois a iconografia também foi utilizada como modo de representação do estrangeiro. "Dizer o outro é enunciá-lo diferente é enunciar que há dois termos, $a$ e $b$, e que $a$ não é $b$ ", sendo a diferença a condição básica

\footnotetext{
25 "Se a narrativa se desenvolve justamente entre um narrador e um destinatário implicitamente presente no próprio texto, a questão é então perceber como ela 'traduz' o outro e como faz com que o destinatário creia no outro que ela constrói. Em outros termos, tratar-se-á de descobrir a retórica da alteridade em ação no texto, de capturar alguma de suas figuras e de desmontar alguns de seus procedimentos - em resumo, de reunir as regras das quais se opera a fabricação do outro" (HARTOG, 1999, p.228).
} 
para a retórica da alteridade, "[o] narrador, pertencente ao grupo $a$ contará $b$ às pessoas de $a$ : há o mundo em que se conta e o mundo que se conta". Há, assim, a tradução da diferença, em que a inversão é importante. "Não há mais $a$ e $b$, mas simplesmente $a$ e o inverso de $a$ ", em que primeiro se levanta a diferença e depois a traduz ou a apreende num esquema de inversão, sendo o princípio da inversão um modo de transcrever a alteridade, tornando-a fácil de apreender no mundo em que se conta (trata-se da mesma coisa, embora invertida), uma ficção que faz ver e compreender. A alteridade, portanto, serve como um anti-próprio (HARTOG, 1999, p.229-231).

Para Gruen, alteridade e criação do outro são mecanismos importantes, tanto no presente, quanto no passado, para a construção da auto-imagem. "Imagens negativas, deturpações e estereótipos permitiram aos antigos inventarem o 'outro', assim justificando marginalizações, subordinações e exclusões. A criação de opostos serviu como um meio para estabelecer identidade, distinções e superioridade". Contudo, o processo era mais amplo e abarcava uma diversidade de visões em que recusas e apropriações estavam sempre presentes (GRUEN, 2011. p.1-5).

Nicolet argumenta que os romanos tinham um determinado conhecimento de mundo (etnográfico, geográfico e diplomático) e que o utilizaram para suas conquistas, bem como para a tradução de suas conquistas. Assim, tais traduções possuem limites físicos e culturais inerentes ao próprio olhar romano sobre o outro e relacionado aos próprios interesses dos romanos em transmitir determinada informação sobre os não-romanos. $\mathrm{O}$ estrangeiro quase sempre era o inimigo, mas, mais classicamente, os povos que viviam fora do território da península Itálica, como os gauleses, os germânicos, os povos do além mar e os gregos, com os quais, segundo Nicolet, apesar da admiração, os romanos também possuíam desconfianças ao mesmo tempo (NICOLET, 1979, p.885-889). Geertz expõe, com relação às leituras dos estrangeiros, que um estudo de determinada cultura sempre se dará de uma segunda mão, pois aquele que está por fora, o leitor/estudioso, sempre estará de fora, por mais que compartilhe de alguns elementos daquela cultura, ou seja, sempre teremos uma leitura indireta (GEERTZ, 1978, p.25-26).

Gruen aponta que em Roma havia uma ação de tolerância com relação a uma absorção cultural externa, tanto que muitos elementos gregos, por exemplo, foram adotados como os livros sibilinos, alguns deuses gregos (inclusive com construção de templos) e o pitagorianismo. O problema se encontrava naquilo que fugia ao controle dos magistrados e senadores, como é o caso dos ritos a Baco, que eram vistos como obscuros e compostos por um grupo que poderia rivalizar com a religião cívica (GRUEN, 2011, p.343-351). Portanto, o 
externo não poderia se opor ao interno para ser absorvido, mas acrescentar e permitir um engrandecimento da $U r b s$ e dos romanos.

Os romanos se utilizaram de elementos culturais advindos dos contatos com os povos estrangeiros, mas devido ao mos maiorum precisaram adaptar os elementos estrangeiros de um modo romano, fazendo com que aqueles, em muitos casos, não fossem a degradação de sua própria estrutura moral e cívica. Cabe, desse modo, analisar quem está dentro e quem está fora dessa fronteira entre o $\mathrm{eu}$ e o outro para que se possa compreender a dinâmica mental existente (BURKE, 2004, p.174).

Apesar dessa visão quase sempre negativa do estrangeiro, havia também uma leitura positiva de alguns povos não-romanos, como podemos observar na época de Augusto. No entanto, essa dinâmica de ler/traduzir de modo positivo os estrangeiros deve ser visualizada dentro dos próprios interesses romanos. Podemos citar como exemplo a utilização da lenda de Enéias pelo príncipe romano na busca de se legitimar na cena política romana, a qual pode ser encarada como um mito fundacional do Principado, e por isso foi utilizada na cultura material (Prima Porta, imagens troianas na Ara Pacis, no Fórum de Augusto) e na literatura, por exemplo, a epopéia de Virgílio. Schneider aponta a existência de uma diferença entre as imagens difundidas na época de Augusto que diziam respeito aos orientais, havendo uma clara diferença entre o asiático (troiano) e o parto, como é o caso claro da couraça da vestimenta militar de Augusto na sua estátua da Prima Porta (SCHNEIDER, 2012, p.76-129).

A criação de um estereótipo, diferentemente do que aponta Burke, é uma das visões possíveis de se ver o outro, não a única possível. Woolf exemplifica com o caso das mudanças do estereótipo dos gauleses da época republicana para a época imperial como esses estereótipos estavam sujeitos a alterações a partir dos contatos estabelecidos ou das mudanças políticas, reforçando como eles devem ser analisados como produtos históricos (WOOLF, 2010, p.255-271).

Nosso foco é tratar da questão do outro, procurando entender como tal elemento se faz importante e necessário para a dinâmica política, como que o oriental foi apropriado pela cena política republicana na fase do Triunvirato e do principado augustano. Para isso, devemos entender como se dá esse processo de tradução do outro em um determinado contexto histórico. O mundo oriental é uma construção, um discurso, um produto histórico. Contudo, observar como os romanos traduziram para seu mundo aspectos do mundo oriental deve ser feito a partir do prisma de discursos políticos. Como já apontado, nosso personagem principal dentro desse complexo processo é a rainha egípcia Cleópatra. 
Portanto, um primeiro questionamento que nos cabe é: o que representava o Oriente para os romanos? Esta é uma pergunta crucial, pois os conceitos são historicamente construídos e aquilo que pode ser visto com um determinado foco por um povo, pode ser encarado de outra forma por outro. Também temos que ressaltar o fato de que quando pensamos em Oriente, possuímos a nossa própria concepção deste conceito, muito herdeira da expansão imperialista européia do século XIX. Assim, como abordar o mundo oriental na Antiguidade, mais especificamente no século I a.C., fase das expansões da República romana? De fato é possível pensar nele? Quando Camous (2007) analisa por um prisma bélico os choques de alteridade, somos instigados a pensar se outros modos de confronto são passíveis de análise para além do confronto militar e dos contatos físicos.

A parte oriental do Mediterrâneo, principalmente, durante os séculos II e I a.C. não deve ser encarada de forma uniforme como uma entidade ou um bloco único, assim como a parte ocidental também não deve ser. Sartre, por exemplo, argumenta que a denominação 'oriental' utilizada nos trabalhos das ciências humanas só é cabível se possuir o sentido geográfico, pois o que se observa nesse mundo oriental é um mosaico de realidades em que os povos são estranhos uns aos outros, mas, ao mesmo tempo, possuem, grosso modo, uma matriz cultural comum, a grega (SARTRE, 1991, p.10). Obviamente que nem todas as sociedades que viviam na parte oriental do Mediterrâneo foram traduzidas pelo setor aristocrático romano como possibilitadores de uma troca cultural/política nefasta a Urbs. Nem mesmo todos os elementos de determinadas sociedades eram vistos como ruins e não poderiam ser apropriados pelos romanos. Dentro desse mosaico de realidades várias leituras eram possíveis e pelos diversos setores da sociedade romana.

Apesar dessa multiplicidade de realidades no Mediterrâneo oriental, acabamos aqui trabalhando com uma realidade política que quase sempre é tomada como um estereótipo de Oriente: a realidade monárquica. Existem muitas realidades políticas no mundo oriental do que propriamente as monarquias, como as cidades-Estado. Estas foram, na verdade, a principal estrutura política oriental, pois mesmo os reis, seja nos grandes reinos, seja nos menores, estabeleceram seus domínios através da conquista e fundação de muitas cidades. A manutenção de um estereótipo oriental típico, o do monarca, se deve, inicialmente, pelo fato de Cleópatra ser uma rainha; segundo, pela monarquia passar por um grande questionamento entre os romanos no último século da República; terceiro, por haver uma crítica de aspiração monárquica por Marco Antônio; por último, por Otaviano/Augusto se colocar contrário ao surgimento de um poder nas mãos de uma única pessoa, no caso a sua, e afirmar que seu 
principado era firmado num compartilhamento igualitário do poder entre os demais magistrados romanos, havendo apenas uma diferença em auctoritas.

$\mathrm{Na}$ época helenística, grosso modo, fase em que Roma passa por seu processo de expansão para fora da península Itálica em direção às outras regiões mediterrânicas, a matriz cultural mais difundida entre os povos que habitavam suas margens era a grega. Como aponta Momigliano, a cultura grega era o modo de tradução de determinada sociedade na época helenística. Os romanos se utilizaram do grego como um instrumento de poder, assim como as suas legiões, o que em muito facilitou sua expansão pelo Mediterrâneo. Os orientais também se utilizaram da cultura grega como meio de tradução de suas realidades, porém, isso se deu de forma muito limitada e calcada, sobretudo, no próprio interesse dos nativos em terem voz junto aos membros das estruturas monárquicas, que compartilhavam desse arcabouço cultural grego, já que eram majoritariamente gregos ou macedônios, e estes não estavam tão interessados em um real conhecimento das realidades vividas por seus súditos ${ }^{26}$ (MOMIGLIANO, 1991, p.13-14).

Desse modo, a forma como foram traduzidas as relações de poder entre romanos e estrangeiros, seja na Urbs ou em outra parte do mundo mediterrânico, deve ser objeto de considerações. Retomamos aqui a idéia anteriormente apresentada de que o mundo oriental se encontrava fora da teatrocracia que regia a cena política romana, na qual a principal filiação deveria ser com relação aos senadores, não com as outras camadas sociais de forma mais clara ou com outros pólos de poder do Mediterrâneo, ou seja, as cidades da margem oriental. Era em Roma que o poder era ganho, exercido, grosso modo, ou perdido, não em outra parte do mundo.

De acordo com Clímaco, que analisa como os reis do Egito foram retratados pelos romanos, nenhuma das obras que narram o período de expansão romana se dedica a fazer uma análise apenas dos ptolomaicos, sendo estes apresentados no decorrer da descrição de episódios a respeito de ações de homens romanos, não recebendo assim o olhar principal das narrativas. O mesmo ocorre no o caso de Cleópatra VII no interior da biografia de Marco Antônio escrita por Plutarco ou seu irmão no caso da decisão do assassinato de Pompeu na biografia deste feita pelo mesmo autor grego. A autora aponta que há uma diferenciação clara no modo como os lágidas são descritos e que isso decorre do próprio contexto de criação

\footnotetext{
${ }^{26}$ De acordo com Momigliano, esse processo de helenização não foi uniforme e com a mesma intensidade durante a expansão dos gregos na época helenística, sendo as trocas culturais diferentes em cada realidade de contato entre os povos que entravam em contato com os gregos, no caso de seu estudo os romanos, os judeus, os persas e os celtas. $\mathrm{O}$ autor exclui, por exemplo, os egípcios e os cartagineses desse processo de helenização, os primeiros por terem declinado e os últimos por terem sido assassinados pelos romanos (MOMIGLIANO, 1991, p.10-11).
} 
dessas narrativas. Os Ptolomeus são descritos de duas formas distintas: enquanto os primeiros são considerados reis benfeitores, os dos séculos II e I a.C. são apresentados pejorativamente, como maus reis, responsáveis pela instalação de um período caótico, o qual só poderia ser revertido com a presença romana na solução dos problemas egípcios, sendo também, nesses retratos, ressaltados os traços, geralmente os mais bizarros, desses reis (CLÍMACO, 2011, p.2-18). Desse modo, visualizamos a forma estereotipada em que se deu a tradução dos reis egípcios para o interior do cenário político romano, sendo o outro visto como inferior ao nós. Cleópatra se enquadra, com isso, dentro de um cenário comum de relatos negativos dos reis estrangeiros, como é o exemplo de seus antecessores no trono alexandrino, apesar de no seu caso, ao menos em Plutarco e Dion Cássio, suas qualidades físicas, de certo modo, serem elogiadas, mesmo sendo usadas como uma arma política ${ }^{27}$.

Assim, observamos como os relatos romanos serviam para, primeiro, auto-promover os próprios romanos, os quais são apresentados como inevitáveis e necessários, não apenas na corte alexandrina, mas em quase todo o Mediterrâneo oriental. O que nos permite até pensar, ainda mais tomando o relato de Políbio que elogia a constituição mista romana (POLÍBIO, História, VI, 18) e que narra os acontecimentos do mundo mediterrânico em sua época, um reforço de uma grandiosidade dos romanos e de sua República perante a fragilidade dos demais sistemas de governo. Segundo, para justificar, no interior do próprio círculo político romano, cujos membros eram quem tinham acesso a essas obras escritas, a expansão para o leste, pois, além do interesse econômico dos romanos (o Egito, por exemplo, era um grande produtor de cereais), era necessária a ação romana para que aqueles reinos não tivessem episódios de revolta, o que colocaria em risco o comércio com essa região. A interferência romana na região passou a ser uma das pautas de ordem política no Senado romano.

Também não podemos pensar que estamos apenas diante de relatos falsos pelo fato do discurso do outro se basear na criação de estereótipos. Não devemos descartar a possibilidade de que muitos dos elementos dos retratos dos reis estrangeiros fossem em parte verídicos, mas que tenham sido exagerados e avaliados por um prisma moral e cultural diferente. Cabe a nós historiadores entender os mecanismos dos discursos e contextualizá-los, não julgar (BLOCH, 2002, p.125-128).

É interessante tomar como paralelo a forma como a Realeza romana é retratada. Quanto à descrição dos reis romanos, visualizamos duas vertentes diferentes. Os retratos

\footnotetext{
27 “[Cleópatra] depositou na beleza todas as suas pretensões ao trono.” (DION CÁSSIO, História Romana, XLII, 34). Plutarco aponta que a rainha não tinha uma beleza que a diferenciava das demais, mas sim seus modos graciosos e sua inteligência que a distinguia de outras mulheres (PLUTARCO, Marco Antônio, 25).
} 
feitos pelos autores antigos sobre os seis primeiros reis míticos de Roma não são baseados nos pontos pejorativos que eles tinham, como observamos anteriormente como relação a alguns monarcas estrangeiros, mas sim, nos pontos positivos de suas condutas, personalidade e naquilo que eles fizeram em prol do povo romano na constituição da estrutura política (TITO LÍVIO, História Romana, II, 1), que seria aperfeiçoada e constituiria a base, grosso modo, da constituição da República romana posteriormente. O único que foge a essa linha é Tarquínio, o Soberbo, o último dos reis romanos, pelo fato de ter assumido o governo de forma ilegal, sem o aval do povo romano e dos senadores, algo característico da República, muito caro a encenação do poder, que pode ser visto como um sinal de um discurso tardio, e feito muitos males à $U r b s$, ao contrário de seus antecessores. Somente aquele que fora contra o povo e os senadores, governando de forma tirânica, seria símbolo de algo negativo? Como Erskine expõe, foi apenas nos séculos II e I a.C. que surgiu nos escritos romanos uma visão pejorativa da Realeza, focada, sobretudo, numa descrição de um mau governo de Tarquínio, no caso romano, e um reforço de pontos negativos dos estrangeiros que se punham como um perigo ao governo dos cidadãos. "Para os romanos da República tardia, os reis eram epítomes de riqueza, poder e prosperidade, mas também eram detentores do poder absoluto e inimigos de um estado constitucional livre". O assassinato de César se insere nesse contexto de aumento do poder de um homem e uma ação violenta de alguns senadores na busca pela contenção de uma atitude monárquica dentro do cenário político romano (ERSKINE, 1991, p.106-120).

A visão negativa da Realeza surgiu no momento em que o sistema republicano passou a estar mais instável com a expansão de suas fronteiras pela bacia do Mediterrâneo, seja pelo contato direto de membros de sua aristocracia com os funcionários e os membros das cortes helenísticas, isso quando não diretamente com os reis, fosse nas cidades orientais, fosse na própria Roma, seja pelo fato desses romanos estarem se tornando poderosos no próprio interior do cenário político romano. Não podemos nos esquecer da função pedagógica desses escritos e como a história romana era encarada como historia magistra vitae, ou seja, um espaço para o recolhimento dos bons e maus exemplos a serem seguidos ou não (CIZEK, 1995, p.9-11).

Tito Lívio nos aponta o espírito guerreiro de Rômulo e seu estabelecimento das primeiras fronteiras de Roma após ele tê-la fundada (TITO LÍVIO, História Romana, I, 7) e a preocupação em povoar de mulheres sua cidade, com a narrativa do rapto das sabinas (TITO LÍVIO, História Romana, I, 9). A refundação de Roma, mas sob o aspecto religioso, empreendido por Numa Pompílio e o seu estabelecimento dos colégios e do calendário romano (TITO LÍVIO, História Romana, I, 19-20). A vitória contra os albinos e sabinos por 
Tulo Hostílio (TITO LÍVIO, História Romana, I, 24-30). A preocupação de Anco Márcio em unir as esferas religiosas e militares na figura real (que detinha maior poder político, mas não a exclusividade da decisão), como imprescindíveis para um bom funcionamento político (TITO LÍVIO, História Romana, I, 32). As reformas urbanas de Tarquínio Prisco que também deu atenção a própria Urbs (TITO LÍVIO, História Romana, I, 38). E o caso da reorganização social em classes e centúrias, com o estabelecimento do censo e as hierarquias sociais (civil e militar) empreendidas por Sérvio Túlio (TITO LÍVIO, História Romana, I, 42-44).

$\mathrm{O}$ relato de Cícero é mais claro quanto à visão teleológica do passado monárquico romano, que, de acordo com o autor, mas pelas palavras de Catão citadas por Lélio, "A constituição da República não foi a obra de um homem nem de um tempo" e Lélio continua "claramente se vêem quantas e quais foram em cada reinado as coisas boas. Mas, afigura-me que chegamos àquele que, dentre todos, me parece ser o que mais e mais claro viu na constituição da República” e Cipião prossegue narrando as reformas sociais empreendidas por Sérvio Túlio que organizou o povo romano em classes e centúrias (CÍCERO, Sobre a República, II, 21). O que exemplifica como Cícero via essa fase monárquica enquanto um momento de gestação da República. E aqui retomamos a Tito Lívio exaltando o fato de a República romana ser capaz de perdurar a Alexandre Magno pelo fato de ele não ter estabelecido a longevidade de seu reino, como os reis romanos fizeram e permitiram que a República tivesse vários varões a seu dispor para as mais diversas ocasiões (TITO LÍVIO, História Romana, IX, 18).

Para nós, mais importante do que saber se de fato os estrangeiros eram uma ameaça ao mundo romano é procurar entender a dinâmica da construção dos estereótipos, da imagem mental do outro, e a sua utilização no interior da teatrocracia do cenário político romano por uma parcela dos atores políticos com uma justificativa de ser em prol de uma 'causa romana'. Contexto no qual pretendemos observar Otaviano/Augusto, Marco Antônio, Cleópatra e o discurso da restauração republicana.

Para entendermos o perigo que Cleópatra poderia vir a oferecer aos romanos, devemos, primeiramente, entender a posição política que ela ocupava e as implicações disso. Ela não era apenas uma mulher ou uma rainha qualquer, ela era herdeira de uma longa tradição de dominação, a qual, mesmo em um trono em crise dinástica durante muitos anos, era simbolicamente muito poderosa. Cleópatra era a rainha de um reino (potencialmente) rico e sua figura era muito simbólica.

Nas margens orientais do Mediterrâneo, entre os séculos III e I a.C., período de expansão romana para essa região, observam-se dois modelos principais de estruturas 
políticas: as cidades-Estado, muitas delas organizadas em ligas de cidades com o objetivo de uma melhor defesa em caso de alguma ação bélica estrangeira e de estabelecimento de uma aliança comercial, sendo dois exemplos disso, na época helenística, as ligas Eólica e Aquéia; e as monarquias helenísticas, que também se utilizaram das cidades-Estado como sustentáculo de dominação do território ${ }^{28}$, sob o domínio direto de um funcionário real, mas a forma como se dava o jogo político ${ }^{29}$ estava centralizado na figura do rei. Com a dominação romana, muitas dessas estruturas citadinas continuaram a ser a base da dominação quando da elevação das elites citadinas a ciuitas romana. Desse modo, havia uma pluralidade de realidades políticas existentes no mundo mediterrânico oriental, em que cidades e reinos coexistiam.

A monarquia helenística foi a estrutura de poder que surgiu no mundo oriental após o esfacelamento do antigo império de Alexandre Magno, em 323 a.C. Ela se ligava às antigas estruturas de governo que existiram nesses locais que haviam tido duradouras experiências autocráticas, como é o caso persa e egípcio, ao desejo dos greco-macedônios de manterem os domínios desses territórios. A discussão sobre a monarquia não era nova, mas sim um tema recorrente da filosofia e da teoria política gregas do século IV a.C. e tomou um novo fôlego, sobretudo no século II a.C., quando da necessidade de criar suportes para a aceitação de tal regime político entre os gregos, pois estes associavam a realeza a um governo estrangeiro e inferior, o dos persas, e criar um modelo de governante ideal. Chegou a estar presente em locais onde antes o Império Macedônio não havia se estabelecido, como Épiro e Siracusa. Walbank aponta que as características compartilhadas pelos diversos locais onde se estabeleceram permitem dizer que a monarquia helenística existiu enquanto instituição, sendo greco-macedônia em sua essência, com pouca influência oriental (WALBANK, 1984, p.64).

Como aponta Tito Lívio, Alexandre não soube dotar seu Império de uma estrutura administrativa que fizesse com que ele se perpetuasse após sua morte, estando o poder e o carisma ligado a sua pessoa (TITO LÍVIO, História Romana, IX, 18). Por isso da necessidade

\footnotetext{
${ }^{28} \mathrm{Na}$ época helenística há um grande movimento urbanístico de fundação de cidades. O próprio Alexandre fundou diversas Alexandrias durante suas viagens em seu Império. Os reis helenísticos usavam essas novas cidades como pilar de estabelecimento de seus governos em seus territórios (pacificar ou defender), sendo elas construídas de acordo com um padrão grego, tanto na forma quanto nos prédios públicos que as compunham. Os Selêucidas são um exemplo disso. Já os Ptolomaicos não fundaram nenhuma cidade, apenas terminaram de construir a capital de seu reino, Alexandria, fundada pelo próprio Alexandre.

${ }^{29}$ Os autores antigos não utilizavam termos ligados a uma idéia teatral ou de jogo como os que empregamos no presente trabalho. Para eles, essa forma de se agir em sociedade era delimitada pela constituição seguida por um determinado conjunto de indivíduos. Assim, eram as constituições (Políbio descreve seis tipos de constituições: monarquia, tirania, aristocracia, oligarquia, democracia, oclocracia (POLÍBIO, História, VI, 3-4)) que determinavam as formas de agir, o comportamento social. Na Monarquia, por exemplo, era com o rei que os indivíduos deveriam se relacionar, sendo ele a cabeça do corpo social, mas sendo sua ação social revestida de uma aura positiva, pois ele se preocupava com o bem-estar de todos os indivíduos. Na Tirania, que também era a constituição política em que um único homem era a cabeça do grupo social, este era caracterizado como nefasto ao conjunto de indivíduos, sendo suas ações egoístas, em prol dele próprio, não da coletividade.
} 
dos novos governantes de criarem estruturas administrativas capazes de possibilitar um governo duradouro e efetivo nesses territórios do antigo rei macedônio. Desse modo, uma verdadeira máquina administrativa foi criada em cada um desses reinos, através da instauração das monarquias, frutos do diálogo entre referenciais anteriores de cada região e elementos da cultura grega, proporcionando um governo menos efêmero e mais bem articulado do que o estabelecido por Alexandre. Walbank aponta que a distinção entre os reis era apenas a questão do título, pois na estrutura de governo adotada, havia pouca diferença (WALBANK, 1984, p.65). Os nativos se utilizavam de termos locais para se referirem a seus reis, como faraó no caso egípcio.

Os reis se viam rodeados por uma corte, sobretudo de origem greco-macedônia, que vivia em palácios luxuosos e confortáveis nas capitais, usufruindo de todos os privilégios que estes podiam lhes oferecer. Compunham o topo da pirâmide social e exerciam os cargos da burocracia estatal. No entanto, não devemos pensar que os membros das cortes helenísticas eram simplesmente predadores, pois dentre eles, sobretudo em Alexandria, mais especificamente ligados ao Museu e à Biblioteca, existiam muitos escritores, sábios e artistas que se dedicavam ao desenvolvimento, à preservação e à difusão da cultura grega e, mesmo, em alguns casos, da cultura bárbara. Era importante para a imagem régia a visão do rei como um patrono da cultura.

Nessa linha, um forte sistema burocrático foi criado ao longo do tempo, sendo a administração real dividida entre membros locais e os funcionários centrais, 'amigos do monarca', cabendo ao rei coordenar tal administração e executar dois cargos principais: o governo do exército e o pontificado máximo, controlando assim, as novas áreas conquistadas, guardando para si o butim das guerras, e o sistema religioso, desde os templos até a ideologia religiosa (LÉVÊQUE, 1987, p.51-55). Os amigos constituíam uma espécie de Conselho de Estado no qual ajudavam os reis em suas decisões, bem como eram membros de uma lista de membros recrutáveis para o exército e para a burocracia real. Sendo assim, a relação entre eles e o rei era uma relação de auto-interesse. As estruturas locais de governo, importantes pólos de poder, como era o caso dos templos egípcios e selêucidas, cabiam aos nativos, que eram os que estavam acostumados com a sua gerência e também os envolvidos diretamente com essas questões. A relação com as cidades dependia da conjuntura política. Havia uma pressão real, mas que deveria ser respondida com elogios e homenagens das cidades e havia em troca doações e outras liberalidades dos reis para com os cidadãos das cidades, ou seja, uma política de interesses mistos (WALBANK, 1984, p.69-74). 
Outra característica desses reinos era a inexistência de um código de leis específico, havendo assim, apenas algumas decisões escritas que constituíam uma série de atos isolados e de casos específicos, que formavam de uma maneira simplória uma jurisprudência e um compêndio de exemplos que deveriam ser afixados nas cidades em conjunto das leis citadinas. Lévêque aponta que isso só era possível pelo rei ser visto como a lei viva e, assim, legislar sem que suas decisões tivessem que ser aprovadas por qualquer conselho ou assembléia, sendo isto, segundo o autor, uma diferença essencial com relação aos gregos e romanos, onde a lei era a expressão da comunidade (LÉVÊQUE, 1987, p.52-53). Podemos pensar que tal atitude, a da correlação entre a vontade real e as leis, era um reflexo do comum pensamento desses soberanos de que o reino era fruto de uma conquista militar e os súditos deveriam servir aos seus desejos. Uma espécie de 'direito da lança'. Entretanto, havia toda a construção de uma imagem idealizada dos reis por trás desse pensamento para que o rei pudesse ser aceito como a fonte do Direito, sendo retratado como vitorioso, corajoso, justo, piedoso com os deuses e afetivo com os súditos, inteligente, que tinha autocontrole, ou seja, era um exemplo moral (WALBANK, 1984, p.81-84). Um artifício importante por garantir uma justificativa do poder e servir de fermento a essa unidade recém criada em cada reino. No entanto, a realidade não se deu como a idealizada em muitos casos.

Quanto a um caráter militar dessas monarquias, Walbank aponta que isso era inerente a estrutura de poder, de que os reis eram homens ambiciosos que confiavam em seus exércitos para sua ação política. Ora, os diádocos, os primeiros reis, eram generais de Alexandre, homens das armadas, sendo a vitória um atributo real, uma forma de se manter a terra conquistada, de conseguir soldados e pagamento de impostos (WALBANK, 1984, p.63; 66).

Um último ponto, o comportamento real. Já foi abordado de que havia uma ideologia de um monarca ideal. Alguns textos foram elaborados com o intuito, tanto de bajular os monarcas, quanto de instruí-los/influenciá-los a serem como os reis ideais deveriam ser, ou seja, podemos pressupor que houvessem regras a serem cumpridas pelos reis, o que os fariam semelhantes ao modelo ideal, e que para isso eles deveriam passar por um treinamento, serem educados a se comportarem como reis, para além de um aprendizado prático obtido através de co-regências. Hahm analisa dois textos do século II a.C., 'Para Alexandre' de um pseudo Aristóteles e 'Para Filocrates' de Aristeu, e demonstra como seus autores através desses escritos buscaram instruir os reis a serem os melhores, a agirem com a razão, se utilizando da moral como um pilar de governo, o que era obtido através da educação (HAHM, 2008, p.458464). Contudo, Walbank argumenta que não se tem como afirmar a relação existente na época 
entre os reis e uma educação à realeza. Ele se pergunta: havia interesse real? (WALBANK, 1984, p.76).

Não pensemos, entretanto, que uma teatrocracia política fosse possível e existente apenas em Roma. As capitais helenísticas ou cidades envolvidas dentro da lógica monárquica da época passavam pelas mesmas situações de manipulação e regimento de um comportamento social pré-estabelecido. A construção de um modelo ideal de monarca pode ser considerada como um desses instrumentos reguladores da ação na cena política, porém, entre teoria e prática sempre houve divergências. Assim, a figura real, com a qual a estrutura política se misturava, por ser a fonte de poder, era o centro regulador da encenação política. A aparência real, com a utilização dos símbolos de poder (diadema, cetro, e outros), era um elemento que distinguia o rei dos demais (nas províncias eles se utilizavam das moedas e das esculturas como meio de distinção e conhecimento da figura central). O próprio uso do luxo, algo combatido entre os romanos, era mais um dos elementos do comportamento social característico das monarquias. De acordo com Walbank, os monarcas deveriam ser ricos, mas não deveriam ter ganâncias, sendo o luxo um modo de exibir a riqueza (WALBANK, 1984, p.67; 84). Assim, observamos uma teatrocracia diferente da romana, a qual os aristocratas romanos mais conservadores não queriam que fosse transposta para Roma, mas com a qual os enviados romanos, como foi o caso de Marco Antônio, eram obrigados a contribuir se adequando à mise en scène local para a obtenção de seus interesses.

\section{Cleópatra, uma ameaça aos romanos?}

Iniciamos nossa análise através de uma breve apresentação biográfica de nossa personagem, a rainha Cleópatra. No entanto, uma ressalva deve ser feita desde o início: falar de Cleópatra é, ao mesmo tempo, falar da sua relação com os romanos. É muito difícil estabelecer um quadro cronológico e analítico de sua vida sem que esbarremos com os homens romanos com os quais ela esteve envolvida. Seja isso pela intricada relação política e amorosa que a rainha teve primeiramente com César e, em seguida, com Marco Antônio, seja pela própria natureza das fontes que usamos para nossa reflexão (as quais também são amplamente utilizadas pela literatura acadêmica sobre a rainha) que são pertencentes ao mundo romano, não a uma realidade egípcia. Assim, como muitos dos estrangeiros, a rainha entra nas narrativas do passado romano como um apêndice de algum personagem romano e suas ações só nos são narradas quando tocam diretamente os homens romanos do relato, não 
havendo uma preocupação da rainha por ela mesma. Hughes-Hallett argumenta que na época de Cleópatra havia três tipos de visões possíveis a respeito da rainha: 1) a visão romana em que ela era uma bárbara depravada e femme fatale que desvirtuou homens romanos; 2) a visão de seus súditos, que a tratavam como uma mãe e uma deusa universal; e 3) a visão das populações helenísticas, para os quais ela seria uma libertadora (HUGHES-HALLETT, 2005, p.31).

Como Finley bem aponta, Cleópatra é uma das mulheres mais conhecidas do mundo antigo, tomando em comparação as pouco conhecidas mulheres romanas, apesar de não ser romana (FINLEY, 1991. p.149-150). Contudo, devemos tomar uma série de precauções com os relatos sobre Cleópatra, pois os romanos a retrataram através de uma visão de mundo específica (tanto de gênero, quanto política, por exemplo), sendo o relato sobre a rainha uma forma espelhada de se observar as próprias mulheres romanas e como uma descaracterização dos homens que com ela se relacionaram, sobretudo Marco Antônio. Portanto, mais do que conseguir construir uma narrativa da vida de Cleópatra, as fontes greco-romanas nos permitem reconstruir a forma como o seu retrato foi construído, como sua imagem foi apropriada e apresentada ao mundo romano. No entanto, nosso objetivo não é observar pelo prisma do gênero, mas da esfera política, das mentalidades.

Cleópatra nasceu em 69 a.C. e cresceu num cenário político muito conturbado em que o trono alexandrino estava sempre no centro de querelas. Seu pai, Ptolomeu XII Aulete, ascendeu ao trono, em 80 a.C., numa conturbada ação dos alexandrinos para evitarem a dominação estrangeira, pois existiam duas possibilidades disso. Primeiro pelos selêucidas, devido a Cleópatra Selene, filha de Ptolomeu VI Filométor e rainha da Síria, que se julgava a única a poder assumir o trono já que era a única com o sangue lágida, e, segundo, pelos romanos, em decorrência dos testamentos de Ptolomeu VIII Evergeta II e Ptolomeu Ápio, os quais legavam o Egito a Roma. A instável posição real de Ptolomeu Aulete, agravada pelo fato de ser filho bastardo do antigo rei, e, assim, não descender de Ptolomeu I Sóter, o fundador da dinastia, fez com que seu governo fosse muito tumultuado e voltado para a conquista de um reconhecimento externo de sua posição enquanto rei do Egito, o que foi obtido em 59 a.C., quando foi considerado 'amigo e aliado do povo romano, ${ }^{30}$. O apoio político e diplomático recebido dos romanos, o qual foi mantido por Cleópatra, foi usado por Aulete para se manter no poder, sobretudo após revoltas alexandrinas e golpes políticos

\footnotetext{
${ }^{30}$ Ptolomeu Aulete manteve estreitos laços com César e Pompeu, triúnviros na época, o que permitiu seu reconhecimento político, claro que a partir de doações do rei egípcio aos generais romanos, que ocasionou as ações de restauração e manutenção no poder alexandrino.
} 
realizados pelas princesas Cleópatra VI Trifena e Berenice (no intervalo de 58 a 55 a.C.), que chegaram a forçar sua fuga do Egito para Roma. Como expõe Schwentzel,

"É nesse contexto de submissão e de humilhação que cresce Cleópatra. Pode-se supor que a tomada de consciência da 'espada de Dâmocles', que ameaçava o trono do pai, não deixou de influenciar seu caráter e de orientar seus futuros projetos políticos. Ao contrário da grandeza passada dos lágidas, o rei do Egito não era mais do que um cliente dos romanos" (SCHWENTZEL, 2009, p.25).

Em 51 a.C., após a morte de Ptolomeu Aulete, subiram ao trono Cleópatra ${ }^{31}$ e Ptolomeu XIII, ambos irmãos, de acordo com a vontade testamental do rei morto e seguindo uma tradição religiosa egípcia. Os primeiros anos de governo da jovem rainha, que então contava com por volta dos 18 anos, conjuntamente com seu irmão, de 13 anos, foram difíceis devido a uma carestia de alimentos por causa das más cheias do Nilo, o que provocou um não pagamento de impostos, e por problemas internacionais na Síria com a ameaça parta aos romanos e a necessidade de envio de soldados ao governador romano. Em 49 a.C., Cleópatra fugiu de Alexandria em razão de uma acusação de conspiração contra o seu irmão, que é atribuída a uma artimanha de Potino, um dos três conselheiros reais, sobre o rei. A situação só se tornou favorável à rainha com os acontecimentos decorrentes da chegada ao Egito dos dois generais romanos com os quais Ptolomeu Aulete possuía tratados de amizade, Pompeu e César, sobretudo este último.

O ano era 48 a.C. e o vento que trazia Pompeu ao Egito era o da fuga após a derrota para César em Farsália. Foi o momento em que a coroa egípcia precisou tomar um partido perante a guerra civil romana. Como Plutarco nos aponta, os conselheiros de Ptolomeu XIII travaram uma discussão no intuito de se saber qual dos triúnviros romanos deveria ser privilegiado na disputa entre eles e César foi o escolhido, o que acarretou o assassinato de Pompeu quando esse chegou próximo ao Egito (PLUTARCO, Pompeu, 107-110).

Após a morte de Pompeu, os ventos levaram para o Egito o seu rival, César. A estadia do general romano em Alexandria foi tumultuada e intensa politicamente. Apesar de ter ido ao reino atrás de seu rival romano, acabou por ter que deliberar sobre a questão dinástica egípcia e ainda vencer uma guerra contra Ptolomeu XIII, a guerra Alexandrina, após uma insurreição deste. Foi nesta estadia que César e Cleópatra começaram a se relacionar política e amorosamente, primeiro, com o restabelecimento da rainha no trono com o apoio do general romano; segundo, com a morte dos conselheiros de seu irmão, bem como o próprio, nas batalhas em Alexandria, o que fez com que a rainha passasse a estar sozinha no trono (apesar

\footnotetext{
${ }^{31}$ Cleópatra VII, pois ela era a sétima homônima a se tornar rainha do Egito.
} 
da associação a monarquia de seu irmão mais novo como Ptolomeu XIV); e terceiro, com o nascimento de Ptolomeu Cesário.

Entre 48 e 47 a.C. César se dedicou a retornar a Roma e solucionar os problemas pendentes com relação à República. Em 46 a.C. ele comemorou seus triunfos, inclusive o da vitória em Alexandria (com a apresentação de Arsínoe, irmã de Cleópatra, como prisioneira), e recebeu um conjunto de honras dentro do cenário político romano. Nesse mesmo ano, 46 a.C., Cleópatra chegou a Roma, onde permaneceu hospedada pelo general romano até sua morte, em 44 a.C., numa casa de campo fora dos limites da Cidade.

Com o assassinato de César, a rainha retornou ao Egito e lá ficou resolvendo questões referentes ao reino. No entanto, as querelas romanas fizeram com que Cleópatra novamente fosse tomada como importante suporte político-militar. Ambos os lados, os cesaricidas e os vingadores de César, recorreram à rainha para que ela os ajudasse na guerra que estava por vir. Ela preferiu apoiar os opositores aos cesaricidas, fazendo alianças com Dolabela.

Em 41 a.C., Cleópatra voltou a se envolver com um importante membro da República romana: Marco Antônio. O encontro ocorrido em Tarso, no contexto da ação política do triúnviro romano no lado oriental do Mediterrâneo, acabou se estendendo com a visita dele a Alexandria e sua permanência lá até o fim do inverno de 40 a.C. quando os problemas italianos de Perúsia e as movimentações de Labieno na Ásia fizeram com que ele retornasse às suas antigas funções. A rainha permaneceu no Egito, enquanto Marco Antônio retornou a península Itálica e estabeleceu um novo tratado de paz com Otaviano, o pacto de Brindes, o qual foi selado através de seu casamento, em 40 a.C., com Otávia, irmã de seu aliado de triunvirato.

Durante um intervalo de quatro anos, de 40 e 37 a.C., Cleópatra e Marco Antônio não se viram. Encontraram-se novamente quando o triúnviro retomou sua reorganização de forças para uma ação militar contra os partos. Nos anos anteriores, ele estivera em Atenas, juntamente com sua esposa, atuando de acordo com suas obrigações enquanto magistrado romano das províncias orientais. Já a rainha egípcia se dedicou ao governo do Egito. Como Hughes-Hallett argumenta, poucos autores se dedicam a tratá-la como uma boa governante, porém, durante seu governo o reino viveu uma estabilidade política com paz interna, sendo ela atenta aos ritos antigos e ao próprio idioma dos nativos. Também houve uma reestruturação econômica do Egito, que voltou a ser um reino rico após a política de financiamento de Ptolomeu Aulete (HUGHES-HALLET, 2005, p.43), tanto que a rainha financiou as campanhas de Marco Antônio e Otaviano se utilizou do tesouro egípcio em suas benesses ao povo romano como as descritas em suas res gestae. 
Desse modo, em 37 a.C., Marco Antônio retomou sua preparação para a campanha parta após seu lugar-tenente Ventídio fazer importantes conquistas militares na Ásia. Diante disso, Cleópatra recebeu um novo pedido de auxílio, o qual foi concedido, a partir de concessões de ambos os lados, e, em 36 a.C., o triúnviro romano partiu para a Partia com o apoio da rainha. O resultado foi uma derrota romana. Nesse ínterim Cleópatra deu à luz a mais um filho de seu relacionamento com Marco Antônio, o que ocasionou o afastamento dela das questões militares.

Após esses acontecimentos, temos, em 34 a.C., os famosos eventos de Alexandria: o triunfo e as doações, como anteriormente abordados. O primeiro deles foi o desfile na capital egípcia do rei armênio Artabaso, que havia traído os romanos e retirado seu apoio na batalha contra os partos, o que ocasionou uma grande complicação para as ações militares de Marco Antônio e a subsequente derrota. O segundo é a doação das terras orientais de Roma à Cleópatra e aos seus filhos, inclusive Cesário.

Os anos seguintes, 33 a 31 a.C., foram os anos de preparação para a batalha contra Otaviano em apoio a Marco Antônio, então seu marido. A rainha teve grande participação neste momento, até porque foi contra ela que a guerra fora declarada, tanto que, de acordo com as fontes, a batalha de Actium foi naval devido a uma decisão dela. Uma forma de se mostrar o poderio das naus egípcias e de uma das patrocinadoras da batalha. Os eventos em Actium são bem conhecidos, em que no ínterim da batalha a rainha foge com sua nau e, ao ver tal artimanha, Marco Antônio a segue, o que acaba por decidir a batalha em favor de Otaviano. Dali em diante os apoiadores de Marco Antônio foram desertando e oferecendo apoio ao seu rival e, com isso, deixando-o sozinho na sua disputa política.

Após a batalha, temos os eventos em Alexandria que precedem os suicídios dos amantes, em que Marco Antônio se fere com sua própria adaga e Cleópatra se deixa ser picada por uma cobra. Otaviano efetua a conquista de Alexandria e do Egito e retorna a Roma para seu triunfo como o único a figurar na cena política romana e como o defensor da República.

Passemos agora a uma análise crítica sobre as relações da rainha e como ela foi vista pelos romanos. Nosso foco agora será observar as relações entre Cleópatra e César, Cleópatra e Marco Antônio e posteriormente entender as razões que a fizeram ser apresentada como uma ameaça aos romanos.

A relação entre Cleópatra e César se deu em duas fases específicas. Foi um contato político e amoroso vantajoso, mas curto, de apenas 4 anos, de 48 a 44 a.C., da morte de Pompeu a morte de César. O primeiro desses encontros seu deu em Alexandria e deve ser visto dentro do contexto da estadia de César no Egito em 48 a.C.. Como já apontado, César 
havia chegado ao Egito após a morte de seu rival que para lá havia fugido, em decorrência da derrota em Farsália, na busca de apoio dos filhos do antigo rei egípcio com o qual tinha relações de amizade. Tomemos inicialmente o relato de Plutarco em sua biografia sobre César. A primeira visão que o general romano teve de Cleópatra nos é apresentada pelo biógrafo em um quadro, de certo modo, teatral, em que a rainha refugiada entra no palácio escondida, enrolada em um conjunto de peças de roupa. Segundo o biógrafo, essa forma astuciosa de adentrar o palácio fez com que César caísse de encantos pela jovem rainha egípcia e, por isso, preparasse a reconciliação entre ela e seu irmão, a qual não foi bem vista pelo jovem rei e por seus conselheiros. Plutarco apresenta que alguns romanos acusaram esse amor pela rainha de ser a razão para guerra travada em Alexandria, mas muitos outros acusaram Potino, um dos conselheiros de Ptolomeu XIII, como o próprio biógrafo argumenta, de tramar contra César e desejar matá-lo em um banquete. O que se sabe é que em decorrência da guerra, os conselheiros e o rei acabaram mortos e a rainha ficou com o trono do Egito, estando também grávida de Cesário. Devemos destacar que em suas palavras, Plutarco, apesar de apontar a relação amorosa entre a rainha e o general romano, expõe que Cleópatra adentrou o palácio após ter sido convocada por César, não por uma vontade pessoal, sendo assim o primeiro contato entre os dois com um fundo político e iniciado pelos romanos, não sendo uma ação com apelo sensual ou dramático premeditado pela rainha (PLUTARCO, César, 62-63).

Suetônio nos traz apenas breves linhas sobre esse primeiro contato entre César e Cleópatra e não deixa espaço para a compreensão de como teria sido esse primeiro contato entre o general romano e a rainha. O autor apenas apresenta que César foi ao Egito atrás de Pompeu e que em Alexandria descobriu que seu rival havia sido assassinado. Enquanto lá estava, acabou percebendo as ciladas que o rei egípcio lhe armava, o que provocou uma guerra difícil de ser vencida devido ao poderio do rei e ao seu pouco apoio, mas que quando a venceu deu o trono do Egito a Cleópatra e ao seu irmão mais novo. E completa dizendo que o general romano fez isso "porque [ele, César] temia transformá-lo [o Egito] numa província que, nas mãos de um governador demasiadamente violento, se tornasse um motivo revolucionário" e assim partiu para Síria (SUETÔNIO, César, 35). As palavras de Suetônio nos mostram uma faceta mais política para a relação entre a rainha e César e sua permanência no trono. O Egito era um reino potencialmente muito rico e que deveria ser mantido longe das mãos da aristocracia romana, como o fez Augusto após conquistá-lo em 30 a.C.. Não sabemos se por detrás desse cálculo político de César havia alguma outra justificativa, ao menos através das palavras de Suetônio. No entanto, o próprio biógrafo aponta que, dentre todos os 
amores de César, contava inúmeras rainhas e que, porém, a que ele mais amou foi Cleópatra e que com ela navegara pelo Nilo até a Etiópia (SUETÔNIO, César, 52).

Já a narrativa de Dion Cássio nos apresenta algumas diferenças com relação a Plutarco e Suetônio. Inicialmente, é nessa primeira aparição de Cleópatra em sua narrativa sobre o passado romano que o autor faz uma apresentação tanto física, quanto intelectual de sua personagem, descrevendo a rainha como uma mulher jovem, bela, com uma voz agradável e de modos encantadores, capaz de fazer qualquer homem cair de amores por ela desde o princípio (DION CÁSSIO, História Romana, XLII, 34). Plutarco só dedica uma descrição da rainha como a feita por Dion Cássio na biografia de Marco Antônio, não na de César, na qual não há nenhuma descrição de Cleópatra (PLUTARCO, César, 62-63; Marco Antônio, 25; 27 28), o que explicita como os retratos de Cleópatra devem ser encarados como frutos de um movimento discursivo específico, o de criação de estereótipos dos rivais, mas apropriados pelos autores antigos de acordo com suas intenções narrativas.

Um segundo ponto de distinção entre Plutarco e Dion Cássio é que para este o encontro entre Cleópatra e César foi arquitetado pela rainha e que ela sabia que deveria ser capaz de em poucos instantes mostrar toda a sua majestade e, ao mesmo tempo, incitar piedade em César com relação a sua delicada posição política. O autor, desse modo, desde o princípio, traça um retrato da rainha semelhante ao presente na biografia plutarquiana de Marco Antônio, em que Cleópatra sabia o poder de presença que possuía e que o usava de acordo com seus interesses. Esse contato foi mal visto pelo rei que atirou ao chão seu diadema ao saber que sua irmã havia adentrado ao palácio e tido um encontro com César. Contudo, o general romano, buscando apaziguar os reis, declara, seguindo o testamento de Ptolomeu Aulete, que os dois deveriam governar o Egito conjuntamente (DION CÁSSIO, História Romana, XLII, 34-35). O único problema foi com relação a Potino, que desagradado, acabou provocando uma insurreição em Alexandria e, assim, a guerra alexandrina, a qual causara uma grande agitação na cidade e problemas para César (DION CÁSSIO, História Romana, XLII, 36-44). Dion Cássio relata que, após esse conflito na capital egípcia e com a morte do rei, o reino foi entregue a rainha por sua boa ação com o romano durante esse ínterim bélico, o que fazia César crer que não haveria mais nenhuma agitação em Alexandria, e que ela deveria governar conjuntamente com seu irmão mais novo e, após isso, partiu do Egito (DION CÁSSIO, História Romana, XLII, 45). 
Há também exclusões nos textos antigos com relação a alguns dados. Essa estadia de César é narrada por ele próprio de um modo diferente em duas obras de sua autoria ${ }^{32}$, a 'Guerra civil' e a 'Guerra alexandrina', escritas nos anos 40 a.C.. Nos dois textos, as passagens referentes à Cleópatra são breves e relacionadas apenas à função de César enquanto apaziguador dos problemas dinásticos egípcios. Ele apenas cita que Cleópatra havia sido expulsa de Alexandria após divergências com seu irmão, o rei Ptolomeu XIII (JÚLIO CÉSAR, Guerra civil, III, 103) e que quando ele chegou a Alexandria apenas tratou das questões dinásticas, restabelecendo a rainha ao trono de acordo com as determinações testamentárias de Ptolomeu Aulete (JÚLIO CÉSAR, Guerra civil, III, 107; Guerra Alexandrina, 33), o que causou descontentamentos entre os conselheiros e aliados do rei e, desse modo, provocou a guerra alexandrina. A exclusão da apresentação de seu romance com a rainha é muito clara e significativa. Ele apenas visava apresentar a importância política das boas relações entre egípcios e romanos, não se dedicando nem a uma apresentação da rainha ou da forma como a conheceu. Poderíamos pensar que com um intuito de evitar rumores, porém, tal característica está muito mais relacionada a própria estrutura literária empregada por César, através do uso da terceira pessoa, em seus escritos.

O que podemos concluir dessa primeira interação entre os dois é que havia uma multiplicidade de interesses envolvida por ambas as partes. César chega ao Egito por acaso, devido a um golpe do destino, mas não deixava, mesmo assim, de ter em pauta questões para tratar. As guerras em que ele se envolvera eram dispendiosas e o Egito, em decorrência dos acordos de amizade, tinha riquezas para dar em contribuição a relação existente com os romanos. A jovem rainha também tinha seus interesses. Muitos deles são levados para o lado romanesco, mas não devemos deixar de considerar que a sedução era uma importante arma na busca de objetivos políticos e que ela soube aproveitar as oportunidades que foram aparecendo. Os autores antigos trazem informações desse período alexandrino de acordo com os objetivos de suas próprias obras, o que provoca certos desencontros nos relatos, mas que não deixam de apontar para uma ligação de cunho duplo entre César e Cleópatra, o político e o amoroso, em que um dependia do outro.

O segundo momento de relação entre os dois é o da estadia de Cleópatra em Roma, de 46 a 44 a.C.. Sobre essa estadia da rainha em Roma pouco sabemos. As fontes não se dedicaram a ela. Plutarco, por exemplo, não fez qualquer consideração a essa ida da rainha a

\footnotetext{
${ }^{32}$ Os autores modernos discutem a respeito da autoria do 'De bello Alexandrino', se ele teria sido ou não escrito por César. Cizek, por exemplo, nem apresenta a obra em sua análise sobre a historiografia romana (CIZEK, 1995, p.95-109).
} 
Roma em sua biografia sobre César. Suetônio expõe que o general romano a levou a Roma e que só a deixou ir embora após dedicar a ela as mais altas distinções e dotá-la de muitos presentes, sendo que permanecia longamente em sua companhia durante os festins. E que foi devido a esse amor que César permitiu que ela colocasse seu próprio nome no filho que ela tivera (SUETÔNIO, César, 52). Apesar disso, o biógrafo romano pouco nos informa sobre as reais ações existentes durante essa estadia romana de Cleópatra, sobre quais teriam sido os assuntos tratados e como a sociedade romana teria reagido a essa presença da rainha egípcia.

O relato de Dion Cássio também é bem sucinto com relação a esses eventos. Sua preocupação, assim como a de Plutarco, é muito mais tocante às ações de César com a sociedade romana do que com a presença de Cleópatra em Roma. Há uma única passagem na 'História Romana' em que ele relata essa presença da rainha na Urbs e também não nos dá maiores detalhes sobre a natureza da estadia, se apenas política ou não. O que o autor apresenta é que César sofreu mais reprovações por seu amor pela rainha, do que por seus atos que estava realizando enquanto um homem político em Roma naquela época. Contudo, reprovações não pelo amor que havia tido em Alexandria, mas sim pelo que ele demonstrava em Roma, já que a rainha estava na cidade hospedada em uma de suas casas (DION CÁSSIO, História Romana, XLII, 27). O amor de César pela rainha já tinha sido alvo de críticas quando ele havia triunfado em Roma, principalmente por causa da exposição de Arsínoe, irmã de Cleópatra, que havia sido levada para Roma e desfilou como uma prisioneira e derrotada de guerra (DION CÁSSIO, História Romana, XLII, 20). Esse segundo momento do casal então, só vem a arranhar ainda mais a imagem do general romano.

Nessa época, apesar de todas as incertezas com relação à paternidade, se era o menino filho ou não de César, nasceu Ptolomeu Cesário ${ }^{33}$. Para a rainha o seu filho era sim fruto de seu relacionamento com César durante a estadia dele no Egito, porém, para os romanos, tal afirmação era muito complicada e questionável. Schwentzel aponta que a rainha era “consciente da importância política que lhe conferia seu novo estatuto de mãe daquele que um dia poderia proclamar-se herdeiro de César" e que foi com esse pensamento que ela associou seu filho a César e não ao seu irmão mais novo, rei conjuntamente com ela, Ptolomeu XIV, como mandaria a tradição egípcia. O seu destino seria decidido em Roma, tanto que para lá ela viajou após o retorno de César a Urbs (SCHWENTZEL, 2009, p.36).

\footnotetext{
${ }^{33}$ Suetônio nos apresenta como os senadores se opuseram com relação a tal afirmação (SUETÔNIO, César, 52). Disposições de Marco Antônio sobre a paternidade de Cesário são mais claras, de acordo com as fontes, nos eventos de Alexandria no final da década de 30 a.C..
} 
A associação entre Cesário e César era tão importante que a rainha, como nos apresenta Silva, buscou cunhar moedas em que teria o tradicional cometa, que representava a ascensão de César entre os deuses, muito utilizado por Otaviano em seu discurso de diui fillius, para reforçar o laço de paternidade de seu filho com o ditador romano (SILVA, 2014, p.159) e elevar, de certo modo, a sua posição no cenário mediterrânico, visto que ser mãe de um filho legítimo de César, segundo sua visão, lhe conferia um elevado status, ainda mais se levarmos em consideração o fato de César não ter tido nenhum filho legítimo e Otaviano ser seu filho apenas através de adoção.

Outro ponto que cabe abordar de forma mesmo que breve é a relação de César com Cleópatra sendo ela uma representante de um sistema político monárquico. Suetônio diz, em sua biografia sobre o general romano, que no século I a.C. havia diversas críticas a um desejo monárquico do ditador romano, tanto que o biógrafo reproduz uma inscrição que teria sido grafada em um busto de César após sua morte: "Bruto, por haver expulso reis foi o primeiro a ser feito cônsul. César, por haver expulso cônsules, foi o último a ser feito rei” (SUETÔNIO, César, 77-79; 81). Contudo, a rainha egípcia não é colocada numa posição de influência sobre um espírito monárquico de César. Ela nem é associada a ele através desse quadro temático, mas apenas dentro da ótica dos amores que ele teve em vida. Assim sendo, essa visão da rainha enquanto uma ameaça a Roma surge apenas com relação a Marco Antônio durante o período de Triunvirato.

De acordo com os relatos antigos, Cleópatra e Marco Antônio têm seu primeiro encontro em 41 a.C., em Tarso, quando a rainha vai à Cilícia após ser convocada pelo triúnviro romano para uma reunião. Inicialmente, como anteriormente apresentado, o teor do encontro seria político, visto Marco Antônio ter sido responsabilizado por reorganizar a região oriental do Mediterrâneo após as movimentações e batalhas contra os cesaricidas em 42 a.C.. No entanto, a visita da rainha Cleópatra se estende com a ida de Marco Antônio a Alexandria durante o inverno, momento em que os laços políticos são selados também com a relação amorosa entre os dois, a qual é interrompida com o chamado italiano devido à confusão provocada por Fúlvia, esposa do triúnviro, e Lúcio Antônio, seu irmão, em Perúsia e pelas movimentações partas na região fronteiriça com as províncias romanas orientais.

Desde esse primeiro momento em que os dois principais pólos de poder de seus povos, a rainha egípcia e o triúnviro romano, se encontram as narrativas sobre o romance e a consequente degeneração de Marco Antônio começam a se rebuscar. Entretanto, o que as fontes não abordam é que os dois já se conheciam anteriormente. Marco Antônio havia sido enviado a Alexandria quando da recolocada de Ptolomeu Aulete no trono egípcio em 55 a.C e 
Cleópatra havia permanecido em Roma entre 46 e 44 a.C.. A exclusão de informações devido a uma intenção bem delimitada de colocar a rainha como um mal ao triúnviro deve ser considerada e trazida à luz para que não nos esqueçamos que estamos lidando com visões de mundo baseadas em discursos políticos.

A relação entre Marco Antônio e a rainha não foi apenas um relacionamento amoroso como os autores antigos nos narram. Havia muitos interesses envolvidos. Ambos os lados tinham fins políticos. Como anteriormente apresentado, Marco Antônio queria o apoio egípcio para a guerra contra os partos e Cleópatra desejava o apoio romano para sua manutenção no trono e em seus desejos de restabelecer a grandiosidade do reino egípcio. A rainha lágida tinha, como aponta Rivero, uma grande meta política em sua vida: se tornar rainha de um grandioso império que reunisse as terras egípcias e romanas, aqui cabe lembrar que Roma detinha o domínio de áreas que outrora pertenceram aos ptolomaicos, como a Celessíria, a Cirenaica e Chipre. Ela era imbuída do ideal da reconstrução de um grandioso império como foi o de Ptolomeu III Evérgeta, o auge de sua dinastia. Assim, devemos ter em mente, que foi, em parte, com esse pensamento que ela se relacionou com os grandes generais romanos Julio César e Marco Antônio. Cleópatra sabia que o seu reino estava em xeque, pois a bacia do Mediterrâneo aos poucos estava caindo ao jugo romano e que caberia a ela promover o prolongamento de sua dinastia. Deste modo, devemos analisar a união entre ela e César e ela e Marco Antônio como um benefício mútuo, assim como foi a de Ptolomeu Aulete com Pompeu e César. Contudo, com Marco Antônio, Cleópatra tinha ainda mais um objetivo em jogo, a proteção dos direitos de Ptolomeu XV Cesário, filho de César, junto ao Senado romano (RIVERO, 2003, p.95). O que não significa, necessariamente, que ela pudesse ambicionar governar sobre o Capitólio

A rainha, desde Tarso, tenta mostrar ao triúnviro romano todas as suas riquezas e esplendor, o que permanece em diversos momentos da relação entre eles. É sempre um festival de banquetes, festas e a demonstração de que ela poderia financiar os intuitos militares dele, como nos apresenta Plutarco, por exemplo. O luxo, combatido em Roma e peça fundamental da encenação helenística, foi a forma utilizada pela rainha para a conquista de Marco Antônio e o estabelecimento das ligações políticas e amorosas deles. Não devemos apenas ler tais relatos pelo foco romano de degeneração e vida ociosa, sendo tomada em consideração a importância que esses eventos vieram a ter dentro do contexto em que estavam inseridos.

Um elemento que vem a reforçar como Cleópatra e Marco Antônio formavam mais que um casal amoroso, sendo, sobretudo, parceiros políticos é a cunhagem de moedas dos 
dois conjuntamente. Os partidários de Marco Antônio podiam fazer essa leitura. Podemos citar as moedas já apresentadas em nosso trabalho (Imagens 3 e 4) ${ }^{34}$. Esses pequenos objetos possuem os bustos de Marco Antônio, sem nenhum símbolo real, e de Cleópatra, com símbolos da realeza, e buscam divulgar ações que estavam sendo empreendidas no mundo oriental.

No entanto, o episódio mais importante no conjunto do Triunvirato é o da leitura do testamento de Marco Antônio, como anteriormente apresentado. Nele observamos uma predileção por Alexandria, já que o triúnviro desejava, de acordo com Suetônio, ser enterrado na capital egípcia, não em Roma (SUETÔNIO, Augusto, 17). Otaviano se utilizou desse documento para demonstrar uma comprovação da degeneração do comportamento civil de seu rival. Contudo, não há, a partir das fontes, como Suetônio e Plutarco, por exemplo, uma apresentação de Marco Antônio como aspirante à monarquia, diferentemente de César. O que há é a acusação de desvios civis, muitos deles relacionados a uma ação de Cleópatra. O temor da dominação monárquica é associado à rainha, que agia sobre um homem servil e degenerado.

Desse modo, Cleópatra também foi alvo desse processo de tradução do estrangeiro pelos romanos. Uma tradução que ocorreu de acordo com o que se desejava na cena política: a busca por uma ameaça. Ela teve seu retrato construído com o intuito de fornecer aos romanos uma oposição e denegrir ainda mais o retrato do outro romano que estava em disputa na cena política, Marco Antônio. Essa tradução merece atenção em nossa análise.

Primeiramente, devemos apontar que a rainha egípcia não foi a única a ser vista negativamente. Ela faz parte de um quadro romano mais amplo de tradução negativa do estrangeiro com o objetivo de auto-valorização do $e u$ romano e isso se dá até pelas próprias fontes que utilizamos como suporte para nossa análise, como apontado anteriormente, que se dedicavam a narrar os bons feitos dos romanos e que inseriam os estrangeiros no decurso dessa descrição do passado. Muitos dos reis de sua dinastia são apresentados pelos seus traços mais bizarros: fiscon, aulete, e outros.

No entanto, apesar de vermos sempre retratos mais negativos da rainha na literatura romana, há uma modificação dos elementos mobilizados pelos autores antigos em suas

\footnotetext{
${ }^{34}$ Silva, em seu estudo, faz um interessante movimento em buscar dar voz a Cleópatra e Marco Antônio através da análise de algumas peças numismáticas dos dois, individualmente e conjuntamente. A autora busca, como ela mesma aponta, "resgatar a imagem de Antônio e Cleópatra não mais como outros, mas como eus, como sujeitos com voz própria", o que se mostra bem interessante por apontar como os dois eram conscientes da importância e do impacto das moedas para a difusão de idéias e ideais e como devem ser lidos como personagens que tinham visões próprias do mundo e que passaram por processos de tradução no mundo romano, Cf: SILVA, 2014, p.156-172.
} 
narrativas sobre o contexto em que a rainha se inseria ou sobre ela. A Cleópatra dos poetas da década de 20 a.C. é diferente da rainha egípcia das obras de Plutarco e Dion Cássio, por exemplo, em que apesar da manutenção do teor de críticas ao comportamento dela e de uma má influência exercida sobre Marco Antônio, ela passa a ser apresentada através da utilização de outros pontos para a composição de seu retrato.

Cleópatra foi considerada por alguns como uma ameaça porque fugia da lógica anterior de supremacia senatorial sobre os reis alexandrinos. Ela era uma aliada, mas que tinha suas próprias armas e meios de jogo na cena política. A rainha soube se impor como uma importante aliada política. Esse é mais um elemento que justifica a criação de uma mítica de medo da dominação egípcia, o que exigia uma descaracterização da rainha em oposição aos senadores.

Portanto, a rainha Cleópatra deve ser vista também como um objeto da propaganda de Otaviano. Os estudos recentes buscaram entender sua historicidade ao longo dos anos e construíram como seria a rainha para além dos traços do discurso do vencedor, visando compreender a natureza de suas relações com César e Marco Antônio e como teria sido seu governo do Egito. Para nós, ela deve ser retomada enquanto uma peça do quebra-cabeça discursivo em Roma e seu retrato analisado para entendermos a posição de Otaviano. Os modos como os traços de seu retrato foram compostos que nos é interessante.

Inicialmente, tomemos os textos produzidos pelos poetas do círculo de Mecenas: Propércio, Horácio e Virgílio. Os três foram contemporâneos aos eventos de Actium e participaram na produção de uma aura legitimadora do Principado através de seus escritos, mesmo que uns mais ativamente que outros, permitindo que Augusto passasse a ser melhor visto enquanto um defensor da República e um bem-feitor para o povo romano.

Entretanto, não devemos pensar que houvesse apenas um projeto ideológico de depreciação da rainha. Otaviano/Augusto se utilizou sim das críticas à rainha e pode até mesmo ter as fomentado, porém, o que possuímos junto à literatura latina são alguns exemplares de críticas, que dentro do universo global do que foi produzido se revela ínfimo, ao menos foi o que o passar dos séculos nos legou. Galinsky argumenta que, apesar de Augusto ter incentivado a cultura e a literatura de sua época, não se deve pensar que houvesse uma ideologia ou propaganda do Principado de um modo pré-estabelecido (GALINSKY, 2012, p.148). O que significa que denegrir Cleópatra era um dos movimentos possíveis, sendo, na maior parte dos textos, o objetivo dos autores a elevação de Roma ou dos romanos sem um paralelo com a rainha ou os rivais do príncipe, como podemos observar com a própria 
forma de agir de Augusto em relação a sua cena de glorificação dos romanos e de seus feitos realizados em prol da ciuitas.

Tomemos como princípio uma das elegias de Propércio:

\begin{abstract}
"O que dizer desta mulher que, recentemente, trouxe a desonra às nossas armas, desta prostituída que se oferecia a seus escravos e que, por preço de seus favores, exigia de seu impudico esposo que ele lhe abrisse as portas de Roma, colocasse sobre seu império o Senado? Fatal Alexandria, terra fértil em enganações, e você, Mênfis, que ensanguentou tantas vezes nossos males, foi sobre seu solo, sobre sua margem que Pompeu se viu raptado de seus três triunfos [...].

Sim, a cortesã, rainha da incestuosa Canopo - marca infamante imposta ao sangue de Filipe - teve a pretensão de opor ao nosso Júpiter o ladrador Anúbis, de obrigar o Tibre a sofrer as ameaças do Nilo, de expulsar a trombeta romana aos sons de trepidante do sistro [...].

De quê serviria de ter colocado fim aos eixos de Tarquínio, - deste Tarquínio que nota de infâmia a soberba de seu nome e daquela de sua vida - se é necessário submeter-se a uma mulher? Desfrute de seu triunfo, ô Roma, e desejos por longo tempo a Augusto teu salvador! Você fugiu, você se refugiou nas embocaduras do Nilo e o Nilo foi tomado de medo; as correntes de Rômulo prenderam suas mãos; eu vi seus braços mordidos por serpentes sagradas; eu vi seus membros secretamente invadidos por torpor e sonolência: 'Não, Roma, desde que você tivesse um cidadão tão grande, esta mulher não estava a temer'; ela disse e o vento, um vento abundante, asseverou sua língua. A cidade que se eleva sobre as sete colinas, a cidade que comanda o universo inteiro provou o terror de Marte e temor de ameaças de uma mulher".
\end{abstract}

(PROPÉRCIO, Elegias, III, 11, v.30-35, 39-43 e 47-58).

Diversos são os elementos de oposição presentes nos versos de Propércio. Para além da acusação de Cleópatra como rainha prostituta (regina meretrix), temos um quadro mais amplo de acusações e estereótipos. Esse aspecto sensual da rainha é um ponto importante, até porque ele é um dos que mais serão retomados pelos autores posteriores quando das narrativas de biografias ou textos cronológicos, como é o caso de Plutarco e Dion Cássio, de certo modo.

O poeta faz a apresentação de uma oposição entre a rainha e Augusto, do Egito e de Roma, de Anúbis e de Júpiter, o que mostra como ele buscou representar dois mundos antagônicos e trazer os aspectos egípcios da rainha em valorização da ação de Augusto enquanto defensor de um lado romano, visto que a rainha, segundo Propércio, desejava reinar sobre os romanos através de uma ditadura feminina, apresentando, assim, Cleópatra como uma ameaça aos romanos. Por suas palavras, ela havia desejado que Marco Antônio abrisse as portas de Roma aos seus desejos de conquista e domínio sob o Senado, ela havia ousado opor deuses com feições de animais, como o citado Anúbis, aos poderosos deuses romanos, como é o caso de Júpiter. Desse modo, Propércio constrói uma Cleópatra como ameaça aos romanos, tendo ela sido contida pelo grandioso Augusto que soube conter os intentos da rainha e salvar Roma dela e da sua dominação egípcia. 
O Egito é trazido como um lugar nefasto, terra de enganações, sendo os súditos da rainha traduzidos para o mundo romano como escravos dela que viviam ao preço de seus favores, fazendo com que eles fossem vistos como inferiores, já que os escravos constituíam a esfera mais baixa da sociedade romana, não tendo direitos básicos de um cidadão, pois não o eram. Com isso, temos um reforço indireto das qualidades romanas e da valorização de Augusto e dos romanos em oposição a Cleópatra, aos egípcios e a Marco Antônio.

Já este último, é trazido apenas como o esposo da rainha, como visto anteriormente, o que é muito significativo, pois ele é apresentado aos romanos como destituído de uma caracterização de cidadão romano, sendo que ele era mais do que isso, era um senador romano que tinha tido atuação no cursus honorum mais elevado da República. Aqui, ao ser descrito como o impudício esposo, ele passa a ser apenas um apêndice da rainha, um homem visto como corrompido por ela, principalmente pelos encantos amorosos/sexuais de Cleópatra. Assim, temos um primeiro exemplo de como atacar a rainha e fazer uma (des)construção de sua figura era significativo também para arranhar a imagem do antigo amigo e rival de Otaviano/Augusto.

Retomemos a ode de Horácio que abre o presente capítulo. O poeta também aborda o temor da dominação estrangeira sobre os romanos. Na ode, observamos a retratação da rainha como um monstro fatal que ambicionava governar sobre as ruínas do Capitólio romano e que com seus soldados horrendos preparava os funerais do império. Não há qualquer menção a Marco Antônio. Apenas Cleópatra, não citada nominalmente, é retratada e colocada como louca e perigosa, o que nos mostra a forma como a rainha foi traduzida para os romanos pelo poeta, como uma clara ameaça a Roma. Os egípcios são apresentados como inferiores, o que denegria ainda mais o próprio retrato de sua rainha, sendo trazidos como homens repulsivos, como doentes.

No entanto, segundo Horácio, a rainha não conseguiu realizar 'seus planos' devido ao feroz gavião, Otaviano, que cumpriu seu papel de defensor da República e a acorrentou, ou seja, a venceu em Actium. Através do texto da ode, podemos notar como o claro ataque à rainha era utilizado como artifício para a elevação da auctoritas de Otaviano, pois a ação dele foi essencial para salvar Roma de uma 'eminente ameaça'. O próprio contexto da ode, o de comemoração pela vitória, fecha o quadro de valorização de Otaviano, já que se exalta um grande feito para a Urbs que trouxe uma onda de paz e certa felicidade, o que não era possível anteriormente com o inimigo tão próximo.

A temática de Cleópatra como uma mulher dominadora de Marco Antônio também pode ser vista através de um fragmento do epodo 9 de Horácio em que ele canta: 


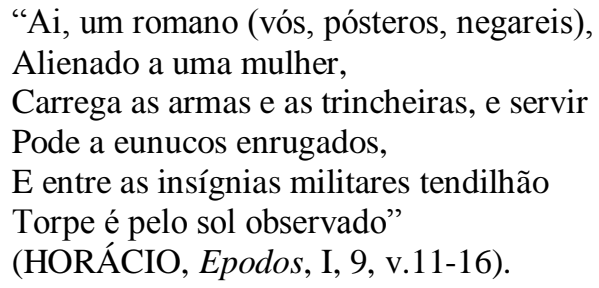

Neste excerto, temos uma apresentação indireta de Marco Antônio e de Cleópatra, mas uma acusação ao poder que ela tinha sobre ele. O fragmento também traz uma alusão aos egípcios, os 'eunucos enrugados', e mais uma vez os termos utilizados são de inferiorização com relação aos romanos, destacando a característica de serem eunucos e possuírem uma característica física que causaria certa repulsa, como deformidades de suas formas físicas, o que também poderia servir para mostrar uma fragilidade bélica.

A literatura romana também nos legou outro exemplo de acusações a Cleópatra. Tratase de uma passagem do livro oitavo da 'Eneida' de Virgílio em que há a descrição dos escudos de Vulcano a serem entregues a Enéias para que ele pudesse combater contra Tulo. Diversas são as representações presentes nessas armas, que retratam desde a loba e os gêmeos Rômulo e Remo à batalha do Actium vencida por Otaviano/Augusto, ou seja, os momentos simbólicos do passado romano (futuro, no caso da narrativa de Virgílio, já que Enéias está vendo ações que ainda estão por acontecer) em que a grandeza de Roma é celebrada. É no interior da representação deste último episódio, crucial para que Otaviano/Augusto pudesse restabelecer a paz, que temos a apresentação da rainha egípcia. Um retrato baseado na dicotomia e numa visão estereotipada, fundamental para que se criasse de fato a visão de mundos antagônicos e de ameaça a Roma.

\footnotetext{
"Também de ouro, a espumar com branca vaga, Representa o cerúleo inchado plaino; Delfins de argênteo brilho, às voltas, o esto Rasgam, de cauda o pélago açoutando. No meio, êneas armadas, Ácias guerras, Todo a ferver Lêucarte em marte instruto, Com o ouro viras fulgurar as ondas. Cá, n'alta poupa, Augusto arrasta aos prélios Senado e povo, deuses e os penates; De ambas as fontes ledo exala flamas; $\mathrm{Na}$ cabeça lhe fulge a estrela pátria. Agripa lá, propícios ventos e numes, Árduo comanda; e a vencedora frota Rostrada se orna da naval coroa. 
Com todo o Egito, ó pejo! segue a esposa

À uma ruem, se empegam; freme e alveja

O mar dos remos e esporões tridentes.

Crês despregadas Cíclades nadarem,

Montes baterem montes: com tal mole

Instam varões das torreadas popas!

Fachos estúpeos voam, farpas zunem,

Rubra do fresco sangue a azul campina,

Sem ver pós si dous áspides, com pátrio

Sistro anima a rainha os soldados.

Contra Palas, Netuno e Vênus, se arma

Com onígenos deuses monstruosos

O ladrador Anúbis: no conflito

Marte, em ferro entalhado, se embravece;

Do éter as negras Diras, e ufanosa

Marcha a Discórdia, espedaçado o manto;

Com sangüento flagelo atrás Belona.

O Ácio Apolo atentando o arco atesa

De cima: de terror o Árabe, o Egípcio,

O Indo, o Sabeu, voltaram todos costas.

Mesmo a rainha parecia os ventos

Invocar, soltar cabos, dar as velas.

Já da futura morte em palor tinta,

Da clade o rei do fogo faz que a tirem

O Iápix e a corrente: mas defronte

Mesto abre o seio, e a veste arregaçando,

Ao verde grêmio e latebrosas fontes

Chama os vencidos os gigantes Nilo"

(VIRGÍlLIO, Eneida, VIII, 665-709).

De um lado estava o bloco representado por Augusto, ajudado por Agripa, que levava ao combate os italianos, o Senado e o povo romano, os Penates e os grandes deuses romanos. Do lado oposto temos Marco Antônio, com as forças bárbaras do Oriente armadas de vários modos, e sua esposa egípcia, e deuses monstruosos, no caso representados por Anúbis. Nessa representação inicial da batalha e das forças que lutaram, temos, por parte de Virgílio, a apresentação de que as forças dos antigos rivais Otaviano e Marco Antônio não eram antagônicas devido a um projeto de restauração republicana que viria a ser instaurado, mas pela própria composição de cada uma. O recurso utilizado pelo poeta foi o de traduzir Marco Antônio como inferior por ter como exército um conjunto de bárbaros e a proteção de deuses que se diferiam dos do panteão romano pela forma física, por exemplo. Marco Antônio tem sua figura trazida de um modo negativo e exacerbado, praticamente, como um não-romano. Portanto, temos claramente uma oposição entre dois mundos diferentes, enquanto Otaviano, já César Augusto, é trazido como o defensor de um lado romano. Ora, não podemos deixar de lembrar que Marco Antônio tinha muitos apoiadores romanos, tanto magistrados, quanto soldados. Eram dois romanos, com seus aliados, que estavam lutando no confronto. No entanto, apontar que eram duas forças opostas era mais engrandecedor ao próprio príncipe e 
forjava uma maior legitimidade aos seus atos, pois falar que ele lutou contra um romano poderia não ter tanto impacto num sentido de defender a República, mas trazer que ele foi o representante de Roma e que a sociedade romana e os deuses romanos escolheram estar ao seu lado é muito mais legitimador e fortalecedor de sua ação.

Nesse mesmo escudo de Vulcano, ao descrevê-lo, o poeta não faz nenhuma referência nominal a Cleópatra, apenas a chama de rainha e esposa egípcia. Esta segunda denominação, por si só, serve como uma forma de atacar Marco Antônio, pois este havia preferido Cleópatra a Otávia. Além de a rainha ser colocada como tendo tido um papel importante na batalha, já que ela inflava seus soldados a lutarem, também há uma indicação de sua morte com um chamado do Nilo. Podemos sugerir que a grande inimiga de Roma, como representado nos escudos, era a rainha egípcia e todo o seu arcabouço cultural nativo que se opunha ao mundo romano que Otaviano se dizia, e que foi representado como, defensor. Marco Antônio é apresentado na narrativa, mas os ataques a ele são feitos através da inferiorização de Cleópatra e dos egípcios, bem como de outros povos orientais que os apoiaram, trazidos como bárbaros, o que nos mostra como atacá-la era sinônimo de diminuir ainda mais o prestígio do antigo triúnviro.

Como podemos averiguar, a seleção dos elementos de alteridade da rainha são bem específicos. Não há qualquer apresentação de Cleópatra enquanto pertencente a um arcabouço cultural helênico, que também era, de certo modo, comum aos romanos. Há apenas a estereotipação do arcabouço cultural egípcio, sendo escolhidos os elementos mais estranhos aos romanos como, por exemplo, a especificação de Anúbis como um dos deuses que agiam ao lado da rainha. Como nos narra Plutarco, a rainha foi a primeira dos ptolomaicos a aprender a língua egípcia, o que tinha um fundo político claro, visto os questionamentos anteriores que a sua dinastia sofrera, bem como procurou se associar ao culto de Ísis, se apresentando aos seus súditos caracterizada como a deusa (PLUTARCO, Marco Antônio, 27; 54).

O que observamos a partir desses textos é que a preocupação dessa época é muito mais de legitimar as atitudes de Augusto do que meramente construir uma narrativa sobre a rainha ou Marco Antônio. Esses autores estavam, de certo modo, inseridos dentro de um movimento de elaboração da mítica do Principado e do príncipe, criando a ilusão da cena política romana. Otaviano já havia na década de 30 a.C. reforçado os pontos negativos da ação de Marco Antônio enquanto um magistrado romano no Oriente perante o povo e o Senado de Roma. A década de 20 a.C., porém, vive outro contexto político, em que o príncipe está 'sozinho' na cena política, mas, mesmo assim, ainda não completamente estável. Era necessário o reforço 
de que a guerra empreendida em Actium, mesmo com o juramento dos romanos em 32 a.C., havia sido legítima, o que fazia com que o reforço das características estrangeiras da rainha fossem destacadas e o lado romano de Otaviano inserido como um pilar legitimador de suas atitudes. Como argumenta Schwentzel, "a rainha confunde-se com o Egito, antítese de Roma, que ela encarna. $\mathrm{O}$ 'monstro fatal' de Horácio e a 'fatal Alexandria' de Propércio representam uma única e mesma ameaça às virtudes latinas. É como se todos os temores romanos do final do século I a.C. se materializassem na personagem de Cleópatra" (SCHWENTZEL, 2009, p.110). O que não podemos é pensar que esse medo fosse natural. Pelo contrário. Há uma construção dessa ameaça egípcia e o papel dos poetas, mesmo que não de modo sistemático, é muito importante para compreendermos a atmosfera política romana da época augustana.

Transformar a rainha em um perigo aos romanos e fazer com que o Egito inteiro fosse englobado nesse contexto através da associação direta a sua rainha e uma inferiorização de seus costumes era fundamental. O que precisamos ter em mente é em que sentido era importante para Otaviano essa visão do $e u$ e do outro. Podemos pensar na encenação política, mas é mais do que isso. Esses escritos também servem, de certo modo, para justificar que o antigo reino recebesse um status provincial diferenciado e que coubesse à administração direta do príncipe. O tesouro egípcio foi uma importante arma para que Augusto fizesse seu amplo programa de benesses ao povo romano, como apontado em suas res gestae. Portanto, além de um interesse político, havia também um interesse econômico que fazia com que o Egito fosse mal visto pelos romanos.

Dion Cássio, já no século III d.C., ao se dedicar à narrativa da época dos preparativos para Actium, traz como um dos pontos de crítica a ação de Marco Antônio a temática do temor de que Alexandria se tornasse a capital do império com a vitória de seu rival. Devido à posteridade da fonte, somos obrigados a ter determinados cuidados ao analisar sua obra e entender que o autor possuía uma visão teleológica, ou seja, já conhecia o desenrolar dos acontecimentos, e que também se utilizou de documentos da época dos eventos para construir sua narrativa sobre o passado romano. No entanto, é interessante notar que ele procura trazer essa idéia do temor para os anos finais da década de 30 a.C. e como costura tal deslocamento por si mesmo sem uma justificativa. O episódio da leitura do testamento de Marco Antônio é colocado como um 'estopim' não só para as preparações de Actium ou para acusações a uma degeneração de Marco Antônio com relação aos padrões de comportamento civil, mas também como uma ação que provava uma preferência dele pelo Egito. Como o historiador romano nos apresenta, "a cólera surgida desta revelação [da leitura do testamento] serviu para confirmar a veracidade dos boatos sobre a conduta de Marco Antônio, ruídos segundo os 
quais, se ele tivesse a vantagem [na guerra], ele deveria dar Roma a Cleópatra e transportar para o Egito a capital do império", o que causou um grande descontentamento, inclusive de muitos que o apoiavam (DION CÁSSIO, História Romana, L, 4). No entanto, em seguida na narrativa, Dion Cássio procura mostrar que Marco Antônio jurou aos seus soldados e aos mais próximos que tudo não se passava de um exagero por parte de seu rival e que ele visava, logo após vencer o confronto, restituir todo seu poder ao Senado e ao povo romano (DION CÁSSIO, História Romana, L, 7). Desse modo, como apresentado anteriormente, temos mais um exemplo de como o autor procura mostrar as ações discursivas que teriam existido na época.

Apesar disso, nesse ínterim narrativo, Dion Cássio acaba fazendo uma apresentação de Cleópatra como se a ameaça houvesse existido. A rainha, através de seu charme, visto como mágico, fez com que Marco Antônio e todos os que estavam ligados a ele jurassem que ela conseguiria dominar o Capitólio, bem como que ele se deixou representar como deuses egípcios e seus próximos permitiram que o nome da rainha fosse gravado em seus escudos (DION CÁSSIO, História Romana, L, 5). O que mostra como Cleópatra estaria se apoderando dos romanos e engrandecendo suas forças para o confronto contra Otaviano.

Entretanto, o que mais merece destaque nesse conjunto de uma apresentação da rainha é, de certa forma, a apropriação de Dion Cássio de alguns elementos presentes nos textos dos poetas anteriormente apresentados como suporte para a construção de como teria sido o discurso de Otaviano ao seu exército durante a fase de preparação da guerra. O autor retoma alguns pontos como a dominação de Cleópatra sobre Marco Antônio; a preferência deste pela rainha enquanto esposa; a adoção de um arcabouço cultural egípcio (como a crença na imortalidade, o emprego da técnica da mumificação e a adoração de deuses que tinham formas de répteis e outros animais); uma guerra de mundos opostos, em que Marco Antônio estava representando os estrangeiros e indo contra os deuses romanos e sua pátria, que Otaviano se punha como defensor (DION CÁSSIO, História Romana, L, 24-28). Portanto, temos mais do que apenas a preocupação da construção de um discurso de Otaviano de exaltação de seu poderio bélico ou de uma guerra justa, temos um deslocamento para o momento anterior a Actium de alguns pontos discursivos de inferiorização da rainha e de Marco Antônio através de um processo de tradução do outro baseado na diminuição dele enquanto meio de fortalecimento do $e u$ (Otaviano). Dion Cássio também insere no discurso de Otaviano o argumento de que para se vencer a rainha era necessário se combater o esposo e que ele estava disposto a fazer isso para salvaguardar os bens dos romanos (DION CÁSSIO, História Romana, L, 28). Obviamente, que devemos ter nossas cautelas com esses textos e 
discursos, porém, não podemos também ignorá-los e pensar que se trataram apenas de informações falsas devido ao recuo temporal dos fatos que narram.

A biografia de Plutarco, escrita no século II d.C., também deve ser trazida à reflexão. O autor não nos traz de forma clara esse temor da dominação egípcia quando da narrativa das acusações entre os triúnviros (PLUTARCO, Marco Antônio, 55). Plutarco procurou trazer para seu texto as tensões existentes com relação às ações de Marco Antônio no mundo oriental e como isso foi sendo utilizado em Roma por Otaviano como meio de críticas a ele e demonstração de sua degeneração. O autor apresenta a ação de Marco Antônio nos cenários políticos do Oriente como em desacordo com o que deveria ser realizado por um romano, fazendo críticas, por exemplo, ao ócio, à vida desregrada e à associação com Baco. Desse modo, o que podemos apontar é que Plutarco abordou em sua narrativa o modo como as ações de Marco Antônio foram utilizadas no intuito de forjar uma acusação de predileção de Alexandria em detrimento de Roma, o que não nos permite argumentar sobre um desejo da rainha em governar Roma.

A temática da dominação da rainha sobre Marco Antônio é um dos pontos mais claros apropriados por Plutarco. Como ele aponta, "Cleópatra deveria ser agradecida a Fúlvia pelas lições de submissão às mulheres que [Marco] Antônio recebeu dela e que fizeram dele um homem aprisionado e acostumado de longa data, quando ele passou às mãos de Cleópatra, a escutar as ordens das mulheres" (PLUTARCO, Marco Antônio, 10). Sendo no interior da narrativa trazidos diversos eventos sobre as ações da rainha sobre o triúnviro.

No entanto, o que não observamos, é uma influência dela enquanto uma egípcia. Cleópatra não é apresentada como pertencente a um mundo completamente diferente de Marco Antônio. Há um antagonismo nos modos de vida da rainha e do triúnviro, o que é até utilizado para criticá-lo quanto a certo relaxamento de seus costumes, o que, porém, não nos permite a visualização de Cleópatra como um monstro fatal, louca para dominar o Capitólio. A forma que Plutarco a insere em sua narrativa, apesar dos estereótipos existentes, pouco se assemelha a rainha dos poetas do século I a.C.. Marco Antônio não é retratado como possuidor de um exército de bárbaros ou como tendo se associado a algum deus egípcio, mas como um romano, com aliados romanos, que saiu do padrão de comportamento social a ser seguido, tanto por razões de sua natureza, quanto por influências de outras pessoas. O modo como Cleópatra é apresentada na narrativa mostra a ligação política entre ela e o triúnviro romano e as ambições de Marco Antônio com relação ao mundo romano, porém, o viés adotado é mais o de inferiorizar o romano pelo contato amoroso com a rainha, que despertou 
muitos males a ele (PLUTARCO, Marco Antônio, 25; 69-70) ${ }^{35}$. A presença de temas como as ações de Otávia e a 'rivalidade' entre ela e Cleópatra na biografia de Plutarco já nos mostram qual o caminho narrativo escolhido pelo biógrafo.

Um breve comentário com relação a Otávia deve ser feito. Ela e Marco Antônio, como já apresentado, se casaram após o acordo da paz de Brindes, em 40 a.C.. A vida do casal foi aparentemente normal, tendo eles vivido juntos em Atenas, quando, no mesmo ano do casamento, para lá se mudaram devido às incumbências de Marco Antônio no Oriente. A irmã de Otaviano foi uma importante peça política, tanto no equilíbrio, quanto no desequilíbrio das forças entre eles. Um autor que a traz mais para as linhas de seu relato é Plutarco, até porque ele compôs uma biografia de Marco Antônio.

O que nos cabe é apontar que nas linhas do biógrafo, Otávia, para além de uma peça política, foi descrita também como um parâmetro de (des)construção do retrato de Cleópatra, sendo a primeira apresentada de modo mais positivo que a segunda, principalmente como bela, mas Otávia tendo a característica de ser um bem a Marco Antônio por suas qualidades e pela paz que ela representava entre os triúnviros, enquanto a rainha egípcia é vista como um mal ao romano (PLUTARCO, Marco Antônio, 38; 43). Através disso podemos, talvez, ver um apontar das boas características dos romanos, em detrimento dos estrangeiros, e da família de Otaviano com relação a Marco Antônio.

Um autor latino que não se apropria dessa temática de uma ameaça egípcia é, por exemplo, Suetônio, que, ao realizar a biografia de Augusto, também no século II d.C., não faz qualquer menção a uma ação de Cleópatra enquanto um perigo aos romanos ou de Augusto como defensor de um temor externo. O biógrafo, como apontado anteriormente, traz como motivo para o rompimento entre Marco Antônio e Otaviano o testamento do primeiro e apresenta que este documento foi a comprovação de uma degeneração do comportamento civil do romano (SUETÔNIO, Augusto, 17). Desse modo, não há nenhuma apresentação da dominação de Cleópatra ou de um auxílio de Marco Antônio no intuito dela dominar Roma. Como no caso de Plutarco, o comportamento social que é o prisma pelo qual transpassa as críticas.

Outro exemplo é a res gestae do príncipe. Não há, no interior do texto, nenhuma referência à rainha como uma ameaça à República romana. Ela nem indiretamente é citada no monumento. Um texto escrito pelo próprio príncipe com o objetivo de celebrar e transmitir à

\footnotetext{
${ }^{35}$ Essa questão da dominação feminina é sempre apresentada de forma negativa. Tácito, por exemplo, descreve negativamente o domínio que Lívia teve sobre Augusto nos últimos momentos de vida do príncipe (Cf: TÁCITO, Anais, I, 3-4).
} 
posteridade os seus feitos em prol da República, não possui qualquer alusão a um perigo egípcio. Isso pode nos parecer estranho, pois em suas palavras, Augusto diz ter combatido contra aqueles que haviam se virado contra a República e não aponta a rainha como uma inimiga que foi combatida, não a utiliza como um meio de depreciação de Marco Antônio, nem de reforço de sua própria ação dentro do mundo romano. Os artifícios escolhidos são outros e nos mostram como a depreciação de Cleópatra não era o único viés de construção de sua auto-imagem. Claro que também não podemos deixar de observar que isso se deva ao próprio fato do príncipe, após 40 anos de principado, já estar melhor estabilizado na cena política e preferir mostrar ao povo romano como ele jogou a antiga mise en scène republicana e, assim, através de uma defesa da República, foi agraciado com todas as suas honras.

Os objetos materiais, como moedas e ornamentos de construções, por exemplo, espaços com uso, em muitos casos, de difusão ideológica, não foram utilizados como um ambiente para a descaracterização da rainha. Como observaremos no próximo capítulo, Otaviano esteve muito mais preocupado em dotar sua cena política de uma aura legitimadora e engrandecedora tanto de si próprio quanto do povo romano, comemorando os seus grandes atos ou de aliados, os quais não foram, explicitamente, associados a uma depreciação da imagem dos rivais. Por exemplo, a moeda em homenagem à conquista do Egito não possui nenhuma referência a Cleópatra, há apenas um crocodilo juntamente da legenda AEGYPTO CAPTA (Cf: Imagem 7). Entretanto, a escolha desse animal como elemento figurativo na peça monetária também pode ser visto como uma apropriação estereotipada do Egito, em que ao invés de se utilizar algum elemento que valorizasse o reino ou marcasse seu passado, o que se procurou foi estabelecer a diferença com relação a Roma, mesmo que através da fauna egípcia.

Sobre as acusações com relação à rainha, Hölbl argumenta que Cleópatra não deve ser encarada como uma ameaça ao Capitólio romano, pois a rainha não permitiu que Marco Antônio invadisse a península Itálica e, assim, encontrasse seu rival desprevenido (HÖLBL, 2001, p.246). O que reforça o fato de termos que analisar essa ameaça como um objeto discursivo com um forte fundo político. Claro que também não podemos ser inocentes e descartar que possivelmente alguma vez ela tenha tido tal intento. $\mathrm{O}$ que temos são relatos que corroboram com os textos pró-augustanos como os versos de Horácio que abrem o presente capítulo e não nos fornecem elementos para uma análise mais 'fidedigna' das intenções da rainha. Portanto, a construção desse retrato nefasto da rainha era importante para a encenação política de Augusto. 
Como observamos, Cleópatra tinha um duplo papel, de acordo com os autores antigos. Ela era perigosa por si própria por ser representante de todo um quadro político-cultural oposto e, assim, considerado inferior aos romanos, sendo sua dominação o fim da ciuitas e dos deuses romanos. No entanto, ela também era uma ameaça com relação ao seu relacionamento com Marco Antônio, visto que a associação de uma pessoa inferior ao triúnviro, principalmente através de uma ação de dominação e de uma relação amorosa, denegriria a imagem dele e fomentaria, para a época dos acontecimentos, acusações que justificassem um confronto entre Otaviano e ele, e para os anos posteriores, uma cristalização de uma ação virtuosa do príncipe em salvaguarda da República.

Esse processo de tradução do outro foi, portanto, peça importante para a própria construção da imagem de Otaviano/Augusto. As leituras e traduções dos estrangeiros eram comuns no cenário político romano, principalmente nessa fase de expansão do poderio bélico, diplomático e político da Urbs pelo Mediterrâneo, e mutáveis de acordo com os interesses dos romanos. Não somente os retratos que possuímos dos reis helenísticos se enquadram nesse panorama, mas também o de muitos outros povos mediterrânicos, porém, são os dos primeiros que nos interessam devido ao fato de Cleópatra ser justamente uma rainha helenística de um reino milenar, o Egito. Seus antepassados foram trazidos para o interior da história romana como fracos e dependentes dos romanos, enquanto ela, mesmo que também pelo prisma da inferioridade, sobretudo por ser uma mulher, tenha sido colocada enquanto uma inimiga a ser vencida, pois desejava governar sobre as ruínas do Capitólio romano. No entanto, essa visão de uma ameaça da rainha passou a surgir, apenas, a partir de seu relacionamento com Marco Antônio.

Cleópatra se encontrava em uma situação política delicada: no início de seu reinado, com relação ao seu irmão Ptolomeu XIII, rei conjuntamente com ela; e perante os romanos, visto todos os acordos estabelecidos por seu pai, Ptolomeu Aulete, na compra de sua legitimidade e sua manutenção no trono alexandrino. Nesse contexto inicial que se observa o surgimento da relação entre ela e César, porém, sem que as fontes nos apresentem a rainha com um olhar temeroso por influenciar o general romano em possíveis ambições à realeza. É apenas com Marco Antônio que esse temor passa a ser caracterizado, principalmente com ele sendo apresentado como enfeitiçado de amores pela rainha, o que o faria lutar contra Roma em favorecimento de sua esposa. O relacionamento entre os dois passou a ser a temática e a parceria política que eles tinham, pois Cleópatra, assim como muitos dos reis orientais, era aliada importante para o restabelecimento da dominação romana na região, não recebeu o 
olhar dos autores antigos. Os anos em que os dois não tiveram contatos, entre 39 e 37 a.C., também pouco foram lembrados nesse processo de tradução do nefasto romance entre eles. $\mathrm{O}$ romance que era um elemento do discurso de temor à liberdade romana.

Desse modo, um estereótipo da rainha egípcia foi estabelecido, com o objetivo de traduzi-la negativamente a setores da sociedade romana. Autores do século I a.C., já no principado de Augusto, nos legaram alguns desses traços de como ela era descrita. Horácio, Propércio e Virgílio, por exemplo, nos mostram uma Cleópatra inferior e nefasta, sendo ela uma rainha prostituta, um monstro fatal, que com deuses com feições de animais e súditos eunucos e deformados, como se fossem doentes, ajudada pelo marido, visava ter as portas do Senado romano abertas e dominar sobre as ruínas do Capitólio. Em oposição a ela estava Otaviano/Augusto, um romano que lutava em defesa da República e dos romanos, com o apoio dos deuses pátrios. Assim, vemos como esse retrato era essencial no plano discursivo, pois ele se construiu como um bom romano enquanto Cleópatra e Marco Antônio, tornado mais inferior a seu rival devido a sua ligação com uma estrangeira nefasta à República e aos romanos, passaram a ser (des)construídos e apresentados como perigosos aos romanos.

Portanto, mais do que apenas trazer Marco Antônio como um degenerado, era também preciso reforçar o seu não comprometimento com a Urbs através da caracterização da mulher com a qual ele se relacionava como um mal à República. Ela não era apenas um símbolo da realeza, a qual era mal vista entre os romanos, mas representante de todo um arcabouço cultural inferior e que poderia provocar uma maior desarticulação dos costumes dos antepassados, provocando um fim da República. Desse modo, lutar contra os dois era estar, segundo seu discurso político, do lado da República e defender os romanos, sendo este o papel que Otaviano/Augusto se vangloriou de ter exercido. Os amantes, desse modo, devem ser tratados como peça importante para a mise en scène do poder de Otaviano/Augusto e do principado romano. 


\section{O COMPORTAMENTO SOCIAL DE AUGUSTO}

"No último dia, perguntando amiúde se já havia tumulto na Cidade por causa de si e pedindo um espelho, mandou que seus cabelos fossem penteados e que suas faces flácidas fossem recompostas e, tendo perguntado aos amigos presentes se acaso lhes parecia que tinha desempenhado convenientemente o mimo da vida, acrescentou ainda um epílogo: 'Como muito bem se atuou, aplaudi,/ e despedi-nos vós todos com alegria”” (SUETÔNIO, Augusto, 99).

O fragmento acima é uma das passagens contidas na biografia de Suetônio sobre Augusto em que o autor narra os momentos finais da vida do biografado, que morreu em Nola, próximo a Roma, em 14 d.C., aos 76 anos de idade. Nele, temos um importante tom colocado por Suetônio de que Augusto questiona aos demais companheiros se havia atuado, realizado o mimo, ou seja, agido politicamente, e também na vida privada, do modo mais corretamente desejado, o que nos explicita como todos tinham um papel a ser realizado, encenado, até pelo fato de ter se utilizado a referência de mimo, um estilo teatral da época.

Visamos observar como Otaviano/Augusto se consolidou na cena política romana, sua ação na teatrocracia política, analisando seu comportamento social, ou seja, a sua apresentação aos demais setores sociais e a forma como a sua diferença perante os demais foi apresentada aos romanos, isso sem que sua ação parecesse corromper os mores e que se adequava ao seu discurso de restauração da República.

Balandier argumenta que

"por trás de todas as formas de arranjo da sociedade e de organização dos poderes
encontra-se, sempre presente, governando dos bastidores, a "teatrocracia'. Ela regula
a vida cotidiana dos homens em coletividade. É o regime permanente que se impõe
aos diversos regimes políticos, revogáveis, sucessivos" (BALANDIER, 1980, p.5).

O termo teatrocracia é muito interessante para se tomar como prisma de análise sobre os sistemas políticos, os poderes e as ações sociais, pois, de acordo com Balandier, a ação política era "um jogo encenado a fim de mostrar os jogos da sociedade, que os faz e desfaz; uma sociologia que não depende da enunciação, mas da demonstração pelo drama”, em que o 
real se traduz através do imaginário e o poder se exerce não pela força ou pela razão, mas sim pelas imagens (BALANDIER, 1980, p.5-7).

O cenário político romano pode ser observado por essa perspectiva proposta por Balandier, como um ambiente de equilíbrio de forças, sendo a cena política estruturada em uma teatrocracia, como o autor propõe, com os personagens políticos fazendo parte desse jogo em torno do poder. A partir dos relatos podemos concluir que havia uma forma préestabelecida de se agir no conjunto social e que ela condizia com a tradição dos antepassados, o mos maiorum. No entanto, não através da existência de uma cartilha de comportamentos. $\mathrm{O}$ que existia era muito mais um plano discursivo de setores da elite que ditavam alguns comportamentos a serem seguidos com relação não somente ao poder, mas em sociedade, fortalecendo uma visão, que deveria ser comprovada a partir das ações, de que o sistema republicano estava baseado numa ação individual em prol da coletividade. Os textos romanos, devido ao fato de serem um dos suportes de tradução do mundo pela elite aristocrática e um de seus suportes de dominação da cena política romana, nos apresentam diversos testemunhos sobre homens virtuosos e nefastos à República, que tinham a sua forma de se portar na vida privada e pública avaliada para o bem da coletividade. Com isso, observamos como o mundo romano é perfeitamente capaz de ser lido por essa visão de que havia uma encenação social que regulava o comportamento social. Portanto, há um plano discursivo e um plano de ação em confluência, o que nos mostra como essa teatrocracia, ou seja, ação na cena política era fruto de uma interação.

Nesse contexto, devemos entender o papel importante que teve a visão de um comportamento moral ou de uma busca de moralização da sociedade. Muitas críticas dessa época se focaram numa decadência moral dos romanos com a expansão das fronteiras romanas pelo Mediterrâneo, como é o caso dos textos de Cícero e Salústio, por exemplo, num contexto de transformações do sistema político, ou seja, da forma de ação na coletividade dos atores políticos romanos, grosso modo, os aristocratas. Galinsky reforça que o que estava em declínio eram os homens, não os mores romanos, por isso a política de Augusto se basear num retorno dos costumes (GALINSKY, 1996, p.59), algo facilmente compreensível quando tomamos as palavras de Cícero (Sobre a República, V, 1-2).

O principado de Augusto se enquadra dentro da mesma lógica, visto não ser apresentado como algo que se opusesse ao que existia anteriormente, mas uma fase de restauração e adaptação da antiga República ao seu novo contexto territorial. Augusto é um personagem central em sua época e a sua forma de legitimação de sua diferença e ação no 
cenário político romano é um ponto que merece ser analisado, pois ele ${ }^{36}$ foi responsável por reorganizar as forças políticas (senadores, plebe, cavaleiros, veteranos, soldados, provinciais e o próprio príncipe) no cenário político romano entre os séculos I a.C. e I d.C., durante a passagem da República para o Império, caracterizando a forma de participação de cada setor social na cena política, que acabou sendo, em linhas gerais, a que foi mantida durante os séculos seguintes. Assim, a cena política romana passa por uma reestruturação e uma nova forma de se comportar socialmente é instituída. Agora temos o príncipe, uma figura ambígua, que deve saber como se comportar perante os antigos membros e instituições republicanas, cabendo aos sucessores de Augusto manter as estruturas daquilo estabelecido por ele em sua reorganização do corpo social e atuação política, seja pública, seja privada, vista a tênue linha que separava as duas esferas da vida dele (assim como de qualquer outro homem com função pública).

Otaviano/Augusto foi um homem marcado por uma grande força dramática e dono de uma grande habilidade política, o que o permitiu se firmar nesse cenário político romano através da criação e manipulação de símbolos, vistos por Balandier (1980, p.5-10) como essenciais para todo político. Ao entrar na cena política, Augusto não passava de um jovem sem experiência que soube aproveitar as oportunidades que lhe apareceram para se firmar no jogo político e centralizar em si uma grande quantidade de poder, por mais que seu discurso diga que seu destaque se dava por sua auctoritas (Res Gestae, VI, 34), sem que parecesse uma usurpação dos poderes republicanos.

No interior desse cenário, Otaviano/Augusto se utilizou de símbolos, imagens e discursos, tanto contra seus adversários, quanto a favor de si próprio, através de moedas, estátuas, construções e textos, para construir as imagens do 'eu' e do 'outro', algo comum no seio da aristocracia romana. Tal artifício era importante para a efetiva implantação do Principado, digo, para a 'restauração da República', de acordo com o próprio. Imagens são difíceis de mudar e de se manter (GOODMAN, 1997, p.124), mas no seu caso era necessário apagar a imagem negativa do período do Triunvirato para se colocar como o homem virtuoso

\footnotetext{
${ }^{36}$ Aqui apontamos Augusto como o responsável, mas sabemos que diversas pessoas estiveram envolvidas nessa encenação política augustana. Não devemos ser ingênuos e pensar que ele agiu sozinho. Ele precisava de apoio e de pessoas que compartilhassem com ele aquele ideal de como era sua posição junto à República. Contudo, as fontes não nos apresentam os nomes das pessoas que agiram conjuntamente com o príncipe, apenas há referências aos cônsules, a alguns outros magistrados ou a amigos de Augusto, como é o caso de Agripa, por exemplo, quando de alguma ação específica deles no cenário mais geral que o do principado de Augusto. Também devemos ressaltar que o príncipe teve um papel importante, pois ele ditava as regras mais gerais. Outra pessoa em sua posição poderia ter agido de outro modo e estabelecido outra forma de governo diferente do Principado, seja num retorno a antiga República de fato, seja no estabelecimento de um regime monárquico. Isso pode ser visualizado, por exemplo, em suas res gestae.
} 
enviado pelos deuses para restabelecer a libertas republicana (YAVETZ, 1984, p.1-3), restituindo a ‘época de ouro' no Lácio (VIRGÍLIO, Eneida, VI, 813-835). Era preciso mostrar que ele era o único compromissado com a Urbs, em comparação aos dois colegas de Triunvirato $^{37}$, e que desejava apenas o bem 'do povo e do Senado romano', de toda a comunidade romana, não desejando impor-se como a espécie de um monarca, que corromperia a lógica comunitária da República, mas sim fortalecê-la, o que o transformou em parâmetro de conduta como governante, tanto que Suetônio atribui a Nero a afirmação de que este governaria Roma segundo os preceitos de Augusto (SUETÔNIO, Nero, 10).

Contudo, mesmo essa forma de encenar o 'eu' e o 'outro' deve ser vista dentro de certos limites. Havia todo um quadro de referenciais a serem seguidos, não podendo ser feito nenhum ataque direto aos rivais ou uma supervalorização do 'eu'. A ciuitas e o mos maiorum deveriam estar bem inter-relacionados com o drama, pois era o conjunto de cidadãos da Urbs peça importante nesse cenário e muitos tinham poder de ação, não apenas Augusto, seja na fase de Triunvirato, seja em seu principado.

\title{
A encenação: a defesa da República
}

\begin{abstract}
"O Príncipe deve se comportar como ator político para conquistar e conservar o poder. Sua imagem, as aparências que tem, poderão assim corresponder ao que seus súditos desejam encontrar nele. Ele não saberia governar mostrando o poder desnudo e a sociedade em uma transparência reveladora. Tomemos pois o risco de uma fórmula: a aceitação resulta em grande parte das ilusões sociais" (BALANDIER, 1980, p.6).
\end{abstract}

Esse pequeno excerto de Balandier é nossa mola reflexiva. O autor, em poucas palavras, expressa como, no interior dessa teatrocracia, deveria agir o principal ator político. Para ele, há um diálogo entre o que tem que ser feito e o que se gostaria que fosse feito, cabendo a ação dramática, inerente aos atores políticos, movimentar a cena política, em que ele mascara seu poder através de uma resposta às necessidades de seus governados. Sendo assim a manipulação simbólica um elemento essencial da ação política.

Augusto pode muito bem ser encarado como o príncipe descrito por Balandier ${ }^{38}$. A associação é perfeitamente possível. O príncipe romano soube agir de modo sábio em sua

\footnotetext{
${ }^{37} \mathrm{O}$ que fica explicitado em duas passagens das res gestae, nas quais ele faz alusões a seus rivais, mas de forma depreciativa. Cf: Lépido (Res Gestae, II, 8); e Marco Antônio (Res Gestae, I, 1; IV, 24).

${ }^{38}$ Não há qualquer correlação entre o termo de Balandier e o título apropriado por Augusto de princeps senatus. Há apenas uma coincidência. O que ocorre é a possibilidade de se visualizar o princeps Augusto enquanto um modelo histórico da noção sociológica de príncipe de Balandier.
} 
ação política que durou de seus $19 \operatorname{anos}^{39}$, em 44 a.C., após o assassinato de César, até sua própria morte, em 14 d.C., transformando-se de um jovem inexperiente politicamente em um modelo político para os príncipes sucessores. Otaviano/Augusto soube se enquadrar em sua época e reorganizar a cena política romana, bem como estabelecer as raízes da administração romana pelo Mediterrâneo, se adequando àquilo que as diversas esferas sociais precisavam, seja o respeito aos mores e restituição dos negócios públicos como desejavam os senadores, seja com a promoção de um bem-estar social (doações, espetáculos e obras públicas) à plebe urbana, seja com a doação de terras ou dinheiro para a compra delas aos veteranos, seja com a elevação das elites locais, sustentáculo da dominação romana, diminuindo a insatisfação anterior da época republicana, entre os provinciais. Como ator político, Otaviano/Augusto representou o papel que lhe cabia, sendo sua encenação de reorganização da República fundamental para o seu próprio estabelecimento na cena política romana. Manter uma fachada republicana, criando assim um sentido ilusório, mas que reconfortava os romanos era essencial $^{40}$. No entanto, não devemos deixar de ressaltar que nem todas as ações de Otaviano/Augusto devem ser visualizadas apenas como parte de uma farsa. Muitas eram necessárias de acordo com a situação do momento.

Também não podemos deixar de destacar o fato de que a própria escolha de como agir na cena política romana por Otaviano/Augusto teve influência dos pensamentos de Cícero, até porque os dois tiveram uma fase de aproximação, logo após a chegada de Otaviano a Roma e as primeiras ações no meio político, antes do estabelecimento do acordo do Triunvirato, o que causou o afastamento de ambos, e a conseqüente lista de proscritos que contava com o nome do orador romano.

Assim, ao analisar Otaviano/Augusto, devemos ter em mente a época em que ele viveu e os elementos que ele tinha para serem mobilizados a seu favor. Os autores posteriores podem sim nos dar muitas informações a seu respeito, porém, nos dizem mais de suas próprias épocas do que de Otaviano/Augusto. De acordo com Burke, o que se deve analisar é o meio termo entre a visão cínica (que acha tudo uma construção pré-elaborada) e a visão

\footnotetext{
${ }^{39}$ Galinsky trabalha com o primeiro fragmento das res gestae de Augusto (I, 1) como elemento argumentativo sobre a própria cronologia imposta por Augusto a sua vida política. No texto não há uma remitência ao momento em que Augusto tomou a toga virilis ou aos Idos de março, pelo contrário. Augusto sinaliza que seu primeiro grande feito em prol da República foi a constituição de seu exército, aos 19 anos, e que através dele que pode restituir a República e assim, conquistar suas honras (GALINSKY, 1996, p.42-53)

${ }^{40}$ Néraudau busca analisar Augusto através desse prisma teatral, sendo que "o interesse essencial da vida de Augusto reside na lição política que ele deu, mostrando como um soberano fabrica uma imagem e a impõe a si próprio e aos outros" (NÉRAUDAU, 1996, p.32). Desse modo, o autor mostra como ele articula sua ambigüidade e sua imagem com a sua época e como a ilusão social e a dissimulação foram importantes na legitimação de Augusto na cena política, na mise en scène. Muito interessante é a forma como ele apresenta o episódio da morte do príncipe dentro desse contexto, sendo mais do que a morte de um indivíduo.
} 
ingênua (que pensa que tudo era uma reprodução fiel ao que existia/existiu), sendo o objeto de estudo a construção simbólica da autoridade de Otaviano/Augusto (o personagem de Burke em sua obra era Luís XIV) (BURKE, 1994, p.22-23).

\begin{abstract}
"Tanto o rei [Luís XIV] como seus conselheiros tinham consciência dos métodos pelos quais as pessoas podem ser manipuladas por meio de símbolos. Afinal de contas, tinham sido instruídos, em sua maioria, na arte da retórica. Contudo, os objetivos com que manipulavam os demais eram obviamente escolhidos a partir do repertório oferecido pela cultura de seu tempo. Tanto os objetivos quanto os métodos são parte da história (...)" (BURKE, 1994, p.24).
\end{abstract}

Wallace-Hadrill em seu texto 'Civilis princeps: between citizen and king' se propõe a fazer uma análise sobre o comportamento social dos príncipes romanos, buscando entender se a sua ação o colocava mais próximo dos reis (superbia) ou dos demais cidadãos (civilitas). Para o autor, não interessa buscar entender qual realidade, se a monárquica ou a republicana, era a dominante, como vem buscando uma parcela da historiografia, pois a ambivalência era inerente à própria posição do governante, se encontrando na própria essência de suas funções. Wallace-Hadrill aponta a ambivalência como visível no próprio tratamento para com a Urbs no qual alguns príncipes se dedicaram mais aos espaços urbanos coletivos, como é o caso de Augusto, do que aos próprios palácios, como fizeram outros, sendo assim a cidade parte republicana e parte autocrática. A própria imagem do príncipe também era ambivalente, de acordo com o autor, como pode se observar com a numismática, que nos mostra a utilização das faces dos governantes, algo não característico das cidades-Estado, e sim das monarquias, em oposição à própria forma iconográfica da representação romana, destituída de adereços monárquicos, e a titulação expressa nesses objetos, que buscava reforçar a característica republicana do poder do príncipe. Outro exemplo também é a forma das decisões particulares e públicas. A linha que separava essas duas esferas era muito tênue, como observamos no caso citado pelo autor sobre o desejo de Cláudio em se casar com Agripina, que foi realizado com o apoio do conselho de libertos do príncipe, mas que por se tratar de uma decisão de interesse público, precisava do aval senatorial e popular (WALLACE-HADRILL, 1982, p.32$33)$.

Wallace-Hadrill elenca cinco elementos desse comportamento social, todos eles considerados essenciais para a etiqueta social: recusatio, senatus populusque romanus, libertas, privatus e officia amicorum. Mas para o autor, dois deles se destacam, a recusatio e a condescendência do príncipe para com os demais setores sociais, sobretudo os senadores, a elite dirigente da República, como os pilares dessa atuação. $\mathrm{O}$ fato de o príncipe se tornar o 
principal vetor do sistema de honras justifica o valor real e prático dele manter a aparência de um cidadão comum, não lançando dúvidas sobre a regência da República, mais prático e necessário na teatrocracia. Um processo importante para a adaptação da cidade-Estado romana a sua situação imperial era parecer ainda republicana, mas dependente do imperador, por mais que nos pareça uma ação falsa e mascarada. A cerimônia significava se mostrar como um simples cidadão, o civilis princeps, manter uma continuidade com o antigo passado republicano e 'depender' do consenso das ordens superiores e da plebe, pois como o próprio autor questiona, "quem era ele para resistir à vontade da comunidade, sendo apenas um cidadão como os outros?". Contudo, nem todos esses elementos de conduta foram presentes em todos os imperadores, visto que nem todos eram 'seguros' no poder, de acordo com o autor (WALLACE-HADRILL, 1982, p.37-41; 48). Passemos a uma análise de Otaviano/Augusto a partir dos cinco tópicos elencados por Wallace-Hadrill.

O primeiro dos elementos do comportamento social elencado é a recusa. De acordo com Wallace-Hadrill, a recusa "é um gesto destinado a comprovar uma elaborada pretensão de que as coisas não são como parecem", não ocorrendo entre os monarcas helenísticos, nem entre os homens da República romana (WALLACE-HADRILL, 1982, p.37). Desse modo, analisar o que foi recusado é um ponto importante, talvez até mais do que aquilo que realmente foi aceito, pois é uma forma de se observar a forma como o príncipe estava efetuando a manipulação simbólica de sua ação política.

Dentro da esfera política, Augusto recusou determinados cargos, apesar das ofertas e determinações feitas pelo povo e pelo Senado romano. Segundo ele, "nenhum cargo contrário aos costumes dos antepassados eu aceitei” (Res Gestae, I, 6). Diferentemente do que havia feito César, que aceitou todas as ofertas do Senado e acabou por ser considerado como uma ameaça a República e assim terminou assassinado por alguns membros senatoriais, Augusto soube frear as concessões senatoriais e populares de honras, buscando apenas se inserir na cena romana sem parecer um corpo estranho a ela, o que já nos mostra o reforço de uma ação em favor da República. A recusa da ditadura ${ }^{41}$, oferecida pelo Senado e pelo povo romano,

\footnotetext{
${ }^{41}$ A referida magistratura havia sido extinta por Marco Antônio em 44 a.C, durante seu consulado, com intuito de evitar futuros problemas à República, como, por exemplo, o que havia ocorrido com César. E esse é um dos poucos pontos que Cícero apresenta como virtuosos de Marco Antônio durante a execução dessa magistratura e de sua vida pública (CÍCERO, Filípicas, I, 2), visto que o orador romano só ressalta os pontos nefastos a República romana, como é o caso de sua fuga para a Gália que teria provocado a discórdia entre Pompeu e César, o que levou ao confronto entre ambos (CÍCERO, Filípicas, II, 22). No entanto, tal ponto não é comentado por Augusto. Deste modo, nos perguntamos se seria mais cômodo para Augusto apenas recusar a ditadura, tendo como base o fato de dentro do sistema republicano ser uma magistratura de exceção ou recusar por ser uma magistratura que nem mais fazia parte da lista de magistraturas existentes na Republica, tendo de ser reativada exclusivamente para que ele pudesse ocupá-la. Os fantasmas da ditadura perpétua e o assassinato de César faziam com que Augusto buscasse outra forma de centralizar poderes em suas mãos.
} 
em 22 a.C., bem como, no mesmo ano, o consulado anual e vitalício ${ }^{42}$ (Res Gestae, I, 5) se enquadram nessa conduta do príncipe. Como também a recusa do cargo de curador único dos costumes e das leis (cura morum et legum) com o poder máximo, sendo, a seu ver, uma deturpação da estrutura romana ${ }^{43}$. Augusto recusou até mesmo a mais alta magistratura da esfera religiosa romana, o pontificado máximo, porém, tal ação foi uma artimanha para reforçar sua encenação de preservação do mos maiorum romano, pois ele não aceitou a magistratura devido ao fato de o antigo pontífice, Lépido, seu antigo aliado/rival de Triunvirato, ainda estar vivo. Assim, além da recusa, Augusto procurou denunciar o antigo triúnviro como usurpador do cargo, se recusando a se assemelhar a ele, mesmo tendo a concessão da plebe romana para que ocupasse a referida magistratura (Res Gestae, II, 10). Ele recusou até mesmo triunfos determinados pelo Senado,os quais eram uma grande honraria para os aristocratas da República (Res Gestae, I, 4) ${ }^{44}$.

As recusas, bem como as ofertas de honras, se basearam no pilar da legitimidade, de terem sido possíveis apenas devido às determinações e ofertas senatoriais e populares. Ora, a partir desse artifício Augusto mostra que a antiga estrutura da República, de que a administração da Urbs, e nesse momento também das províncias romanas, seguia as vontades do Senado e do povo de Roma e não as suas. Que mesmo apesar de sua grande importância na cena política romana tudo que ele assumiu ou recusou foi em função de determinações populares e senatoriais, que a esses dois pólos que cabia escolher e determinar como se daria o funcionamento de Roma e de suas províncias, seguindo os preceitos da República. O que nos remete ao segundo ponto levantado por Wallace-Hadrill, o senatus populusque romanus, um importante artifício de reforço de que tudo era feito seguindo as regras republicanas.

Em suas res gestae, para tomarmos o próprio relato do príncipe como base, Augusto elenca algumas das honras concedidas a ele pelo Senado e pelo povo romano ${ }^{45}$. Como

\footnotetext{
${ }^{42}$ A recusa do consulado vitalício talvez seja o desejo de ainda manter uma fachada republicana ao seu poder, que foi fundamentado através do recebimento do imperium proconsulare, em 27 a.C., sendo este reforçado e tornado maius em 23 a.C., e da tribunicia potestas, em 23 a.C., poderes que eram renovados de tempo em tempo, sem estarem ligados a uma magistratura específica, ou seja, uma quebra velada da tradição. Após anos de consulados consecutivos, de 30 a 23 a.C., o príncipe só voltou a ocupar a referida magistratura em dois outros momentos específicos, 5 e 2 a.C., quando da tomada da toga viril por seus netos, Caio e Lucio César, respectivamente.

${ }^{43}$ Apesar de Suetônio apontar que a referida magistratura foi assumida pelo príncipe com caráter perpétuo (SUETÔNIO, Augusto, 27).

${ }^{44}$ Pode-se pensar que o príncipe não precisava mais deste espaço como momento de encenação de seu poder na teatrocracia política romana.

${ }^{45} \mathrm{O}$ documento epigráfico de Augusto pode nos parecer tendencioso, pois seu objetivo é justamente mostrar que ele próprio havia restaurado a República (Millar nos aponta que este é o único documento da época com esse discurso (MILLAR, 1973, p.64-65)), mas é por isso mesmo que ele nos é importante. Corassin expõe que o referido documento possui uma grande importância histórica "pois apresenta o principado descrito pelo seu autor" (CORASSIN, 2004, p.185), o que o torna uma fonte fundamental para se tratar de um período tão
} 
exemplos de determinações senatoriais por ele elencadas, temos: a sua ascensão ao Senado e as honras consulares a ele oferecidas (Res Gestae, I, 1); triunfos, sacrifícios em seu nome aos deuses imortais (Res Gestae, I, 4), votos a sua saúde (Res Gestae, II, 9), a inclusão do seu nome nos cantos sálicos, o que lhe conferia uma sacro-santidade (Res Gestae, II, 10); a construção dos altares da Fortuna Redux (Res Gestae, II, 11) e da Paz Augusta (Res Gestae, II, 12), bem como o fechamento dos portões do templo de Janus (Res Gestae, II, 13); no campo político, a ditadura e o consulado anual e vitalício (Res Gestae, I, 5). Como exemplos daquilo que lhe foi oferecido pelo povo, ele cita: o seu primeiro consulado, em 43 a.C., o Triunvirato $^{46}$ (Res Gestae, I, 1) e o pontificado máximo (Res Gestae, II, 10). Sendo a curadoria dos costumes e das leis com poder máximo, por ele recusada (Res Gestae, I, 6), os títulos de Augustus, juntamente da coroa cívica (corona civica) e do escudo das virtudes (clupeus virtutis) (Res Gestae, VI, 34), e o de pater patriae (Res Gestae, VI, 35) a ele oferecidos por ambos, pelo povo e pelo Senado romano conjuntamente.

Portanto, a etiqueta social permanecia como na República, com uma ação mais coletiva sendo a forma de se encenar o jogo, não cabendo somente a Augusto um papel preponderante em toda a cena. Como aponta Crook, Augusto usou sua auctoritas como o caminho propiciador para realização de suas decisões. No entanto, estas não tinham força de estatuto, pois outras vozes também deveriam ser ouvidas no interior do conjunto da ciuitas (CROOK, 2001b, p.116-122). Desse modo, não devemos pensar que a manutenção do jogo republicano seja apenas uma farsa. Scheid argumenta que os canais eleitorais permaneceram existindo sob o governo de Augusto, o que descaracteriza sua ação política como uma monarquia e mostra como os demais aristocratas também tinham participação na encenação do Principado através dos mandatos das mais diversas magistraturas romanas, sejam as da tradicional República, sejam as que foram criadas durante o principado de Augusto. O autor também elenca a forma de transmissão do poder como um elemento que reforça a importância dos demais setores sociais no jogo político (SCHEID, 1990, p.21-29; 45). Segundo Suetônio, Augusto pediu para que os aristocratas romanos o ajudassem na tarefa de promoção do bemestar social como as obras públicas (SUETÔNIO, Augusto, 30), o que nos mostra a preocupação de Augusto não centrar na sua pessoa todas as incumbências dos negócios

importante em Roma como o principado de Augusto, além de ser um dos melhores exemplos do discurso do príncipe, mostrando-nos, em detalhes, como o governo de Augusto foi construído e legitimado, já que o próprio governante nos mostra quais foram os mecanismos adotados por ele e qual teria sido a sua principal preocupação ao realizar sua obra política bem como o reconhecimento obtido por sua ação na cena política romana através das diversas honras recebidas.

${ }^{46} \mathrm{O}$ Triunvirato tem que ser visto como um elemento discursivo inserido na própria lógica que permeia seus feitos elencados em sua res gestae. O acordo do Triunvirato feito entre ele, Marco Antônio e Lépido era inicialmente ilegal, sendo apenas aceito após a aprovação da Lex Titia, em 43 a.C., durante seu consulado. 
públicos e mostrar para a sociedade romana, o povo e os senadores, que eles eram parte importante do Principado.

O terceiro ponto elencado por Wallace-Hadrill é a libertas. Um ponto sempre tão recorrente nas obras dos aristocratas, ela é um dos elementos essenciais para a encenação política do Principado justamente por ser um dos pilares da República. Nenhum romano queria o seu oposto, a servidão, pois esta era uma característica das monarquias e tiranias.

Dessa forma, era muito importante para Augusto se mostrar como promotor da paz e mantenedor da libertas, tanto que logo no princípio de suas res gestae diz: "Aos dezenove anos, formei um exército por minha iniciativa e às minhas custas. Com ele restituí a liberdade à república oprimida pelo domínio de uma facção" (Res Gestae, I, 1). Sua auctoritas dependia não só das virtudes e dos símbolos, mas também da garantia de que todos continuavam atuando enquanto membros da República. No entanto, nem todos são favoráveis a essa visão de que Augusto fundou seu principado na manutenção da libertas. Tácito aponta que uma das primeiras coisas que aconteceram com a ascensão de Augusto foi a supressão da libertas (TÁCITO, Anais, I, 4).

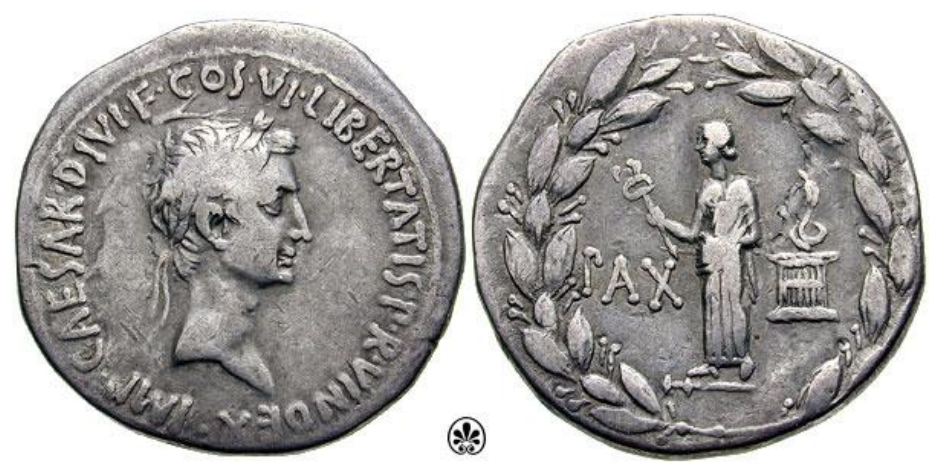

Imagem 6 - Moeda de Augusto em homenagem a reconquista da Ásia (RIC 0476); - tetradraquima de prata (Éfeso); - cunhada em 28 a.C.;

- Anverso: IMP CAESAR DIVI F CÓS VI LIBERTATIS P R VINDEX - cabeça de Augusto laureado;

- Reverso: PAX - Paz portando um caduceu, uma serpente sobre a cista mítica de Baco, borda laureada;

Através da numismática Augusto procurou se mostrar também como um restaurador da libertas. Acima temos uma peça numismática muito simbólica (Imagem 6), pois nela temos no reverso a Paz portando um caduceu, que é um elemento que simboliza o equilíbrio de forças, ao lado de uma cista mítica do deus Baco com uma serpente sobre ela, o que podemos interpretar como uma referência a Marco Antônio. Ora, ele trazia a Paz com relação a alguém que poderia estar oprimindo ou viria a ser um opressor da República. Quanto ao anverso temos a efígie de Augusto laureado, o que o mostra como realizador de uma boa ação 
em prol da ciuitas, como a legenda explicita, além de sua titulatura de cônsul, imperator, César e diui filius, LIBERTATIS (Liberdade) e P[opulus] R[omanus] VINDEX (povo romano vencedor). Desse modo, temos nessa peça um reforço de sua ação positiva através da utilização de símbolos comumente empregados na numismática, o que tornaria o retorno da libertas visível a muitos outros que viviam em terras romanas pelo Mediterrâneo, além de se mostrar superior ao antigo rival, mesmo apesar da ameaça de dominação ter sido ligada a Cleópatra.

Um quarto elemento importante da etiqueta social do civilis princeps é a sua ação enquanto um privatus. Sabemos muito bem da tênue linha que separava a esfera pública da privada na vida do príncipe, bem como de qualquer outro membro da aristocracia romana que tinha funções na administração pública. Ser um homem virtuoso no ambiente privado tinha reflexo nas suas ações enquanto um magistrado romano. Desse modo, era necessário que se tivesse um cuidado maior com o mundo íntimo para que ele não fosse a causa de desgraças ou críticas públicas. Com relação ao príncipe, sua autoridade o punha acima das leis e dos demais, mas essa mesma autoridade o freava, pois ele deveria se atentar a uma não deturpação do sistema coletivo que pautava a República. Ora, como aponta Braund, o príncipe dentro da estrutura republicana/imperial não passava de um senador como os demais, claro, o mais proeminente senador, até mesmo pelo título de princeps senatus, o que nos demonstra sua situação delicada na teatrocracia política (BRAUND, 2002, p.65-67).

A ação de Augusto nesse tópico é considerada por muitos como exemplar, tanto que a vida de Augusto narrada por Suetônio em 'Vida dos doze Césares' não se pauta em uma divisão dos feitos virtuosos e dos feitos nefastos, como observamos em outras biografias do mesmo conjunto, mas na ação de Augusto enquanto um homem público e um homem privado, sendo ambas as esferas indissociáveis, o que nos alude ao fato de sua vida ter sido virtuosa nas duas esferas, não cabendo uma divisão quanto as virtudes ou falta delas, mas quanto aos meios de ação, se privado ou público ${ }^{47}$. De acordo com o próprio Augusto, em suas res gestae, ele buscou ser um exemplum a sociedade romana (Res Gestae, II, 8), o que pressupunha uma ação virtuosa nas duas esferas. O que não significa, porém, que houvesse apenas uma forma de se ver Augusto e sua vida. Tácito nos apresenta dois retratos do príncipe, um positivo e um negativo, em que ele de um homem virtuoso é também visto como um 'usurpador e oportunista' (TÁCITO, Anais, I, 9-10).

\footnotetext{
${ }^{47}$ Suetônio nos apresenta a conduta particular de Augusto desde seus hábitos até as relações com seus familiares e eventos como as mortes, a expulsão das Júlias (sua filha e sua neta) e o casamento com Livia e como esses refletiram em sua ação pública. Contudo, devemos tomar cuidado com o texto de Suetônio por ele estar escrevendo muito depois da vida de Augusto, pois ele pode ter tomado algo pontual como estrutural.
} 
Outro ponto que reforça sua ação como um privatus, mas em prol do povo romano, está descrita em suas res gestae. Um grande trecho do documento se dedica a apresentar à sociedade romana os gastos efetuados pelo príncipe em prol dos cidadãos romanos, cerca de 600 milhões de denários (cerca de 2 bilhões e 400 milhões de sestércios) de acordo com o apêndice do documento (Res Gestae, apêndice, 1). Todos os itens de promoção do bem-estar social como doações, obras públicas e jogos foram realizados não pelo fiscus romano, mas foram retirados do patrimonium de Augusto, advindo da herança familiar e das presas de guerra, como o tesouro egípcio, por exemplo. Desse modo, as impensae de Augusto presentes em suas res gestae foram fruto de sua ação enquanto um privatus e tiveram um grande reflexo em sua vida pública (Res Gestae, I, 5; III, 15-18; IV, 19-20, 22).

Como quinto ponto, Wallace-Hadrill elenca aqui um elemento da prática social que nos é muito mais característico das próprias realidades monárquicas que é o officia amicorum. Não há como deixar de lembrar dos episódios tão característicos da corte francesa e do palácio de Versalhes no que concerne a um grupo de amigos que estava em 'função' do principal ator político (BURKE, 1994, p.99-103). No entanto, o autor aponta que deveria haver uma espécie de dom e contra-dom, em que ambos os lados fossem condescendentes uns com os outros. Cabendo assim uma encenação de que os príncipes e seus amigos estivessem em paridade uns com os outros. O que diferenciava das demais cortes em que o que ocorria era puramente uma bajulação real, não que isso não tenha propriamente ocorrido também em Roma. Outra diferença é a elevação desses amici ao quadro de magistraturas romanas. Poderia sim haver um apoio nas eleições ou uma indicação por parte do príncipe, mas o próprio fato deste não possuir o controle do jogo eleitoral o impedia de fazer imposições de tal tipo como ocorria, por exemplo, nas cortes helenísticas em que os amigos dos reis eram os membros da burocracia real, sendo a escolha para os postos feitos de acordo com a vontade real, não de acordo com a vontade coletiva como na Urbs.

$\mathrm{Na}$ época de Augusto é difícil se falar de uma estrutura como a do officia amicorum. Não que não tenha havido uma ação com tais características em que o príncipe e seus amigos deveriam agir com base no dom e contra-dom. É uma realidade muito mais visível nos principados posteriores, até mesmo devido ao fato de Augusto ter reorganizado o Senado, fazendo ainda com que as raízes da elite imperial começassem a surgir. Entretanto, também não podemos ser ingênuos e acreditar que Augusto não se utilizou de amigos em sua ação política. Ora, as fontes nos deixam claras as ações políticas de Agripa e Mecenas, um na estrutura político-militar, tanto que tinha os mesmo poderes do príncipe, sendo inferior apenas 
na auctoritas, enquanto o outro se utilizou das letras e de seus escritores protegidos para dotar o Principado de uma áurea legitimadora.

O apreço dos mais diversos setores sociais por Augusto nos é conhecido, seja pelas fontes escritas, como é o caso da descrição das honras recebidas pelo príncipe em sua própria res gestae, seja pela cultura material que nos legou diversas estátuas e objetos de arte que remetiam ao príncipe em diversos locais do Mediterrâneo. Ora, todos os membros desses setores sociais eram peças da teatrocracia, pois todos dialogavam para um bom funcionamento do sistema.

Outras características podem ser acrescidas à observação do comportamento social de Augusto, como, por exemplo, a simplicidade de seus modos e vestimentas e o fato de ser uma espécie de 'patrono das artes'. Contudo, para que possamos analisá-las, precisamos, inicialmente, fazer uma consideração. Um elemento deve ser inserido no debate sobre a teatrocracia política romana: a relação com o mundo oriental. Um primeiro ponto que deve ser destacado é que o Oriente se encontrava fora dessa teatrocracia romana. A relação política deveria ser estabelecida com o Senado e com o povo romano, ou seja, entre os cidadãos da Urbs, não apenas com outros povos romanos ou em outros cenários políticos no Mediterrâneo. Já vimos que os contatos externos se transformaram em suporte para críticas a aristocratas que 'fugissem' dos padrões antigos determinados pelos mores. Também já observamos como os romanos estiveram em estreito contato com pessoas, sejam estrangeiros em Roma, como reis, funcionários reais ou magistrados citadinos, imigrantes ou escravos, seja a própria população nativa das áreas em que estavam os soldados, os comerciantes ou magistrados romanos no Mediterrâneo; idéias ou produtos materiais, como bens de consumo ou obras de arte. Desse modo, reforçar a importância do estabelecimento de uma relação sólida, sobretudo em Roma, entre os seus cidadãos se fazia necessário para que a República não sofresse tanto com os reveses advindos com a expansão das fronteiras. Isso, claro, na esfera política, visto os diversos problemas de ordem social que já assolavam os cidadãos romanos, principalmente os mais pobres, não serem objeto da pauta e dos interesses dos aristocratas romanos da época e quando o eram serem indicativos de uma tentativa de corrupção da tradição, como é o caso dos irmãos Gracos, não algo propriamente salutar ao sistema.

Méier expõe que Augusto se constituiu na alternativa para a manutenção do sistema aristocrático romano devido ao apoio do Senado a ele, sendo esse o ponto que o diferenciou de César e de Marco Antônio e o que o possibilitou se firmar no poder, visto a legitimação que ele lhe conferia. Ser o representante da Itália, confirmado pelo juramento de 32 a.C., deu 
ao diui filius a legitimidade de sua proposta para a República, proposta que se casava com os interesses dos aristocratas de manutenção de certo domínio na cena política, que, mesmo com a sobreposição da casa imperial sobre as demais estruturas sociais, permitiu que o governo continuasse, mesmo que hoje vejamos, em parte, como de forma ilusória, sob a égide 'do Senado e do povo romano' (MEIER, 1993, p.54-70). Otaviano/Augusto teve que mostrar que ele não encenava o jogo político de acordo com a sua própria vontade ou seguindo outras regras existentes no Mediterrâneo, como é o caso das monarquias, mas sim de acordo com o padrão dos mores romanos. As críticas a Marco Antônio, como abordado anteriormente, se inserem justamente dentro desse quadro de mostrar como o rival havia se tornado um estrangeiro aos próprios romanos.

Wallace-Hadrill argumenta que alguns imperadores se valeram de elementos helenísticos ou orientais em suas ações políticas. No entanto, o autor deixa em aberto, não fazendo maiores considerações sobre esse ponto em seu texto sobre o que viriam a ser esses elementos, o que nos mostra como tais elementos significavam uma fuga do padrão romano de conduta, um exemplo disto pode ser Nero. Como aponta o autor, o Principado era uma negação da realeza, como já apresentado, sendo os elementos desta aceitos quando não se tornavam condição básica (WALLACE-HADRILL, 1982, p.36; 40-41).

Augusto, ao fazer a utilização de referenciais estrangeiros, buscou não trazê-los a sociedade romana de forma tão impactante, fazendo isso de forma mais velada e aceitável à antiga aristocracia romana. Ora, sua política de restauração da República através dos costumes dos antepassados lhe servia como freio para a absorção de elementos estrangeiros. Contudo, como aponta Zanker, o fato da consolidação de Augusto na cena política fez com que se tornasse muito mais fácil a absorção de um determinado padrão de elementos advindos do exterior, os quais foram, inclusive, absorvidos por toda a elite romana, isso porque não havia mais aquela disputa entre grupos opostos dentro da elite romana, sendo o príncipe mais livre e imitável (ZANKER, 1988, p.239-263).

O príncipe, no entanto, não buscou fazer uma associação a sua figura propriamente pessoal desses elementos estrangeiros, não transformando assim esses elementos grecoorientais como características de sua encenação social, como foi o caso de outros aristocratas, por exemplo, como Marco Antônio e sua vida desregrada na corte alexandrina, na qual ele era membro de um grupo conhecido como 'os inimitáveis' e se desfrutava em seu ócio de diversos banquetes (PLUTARCO, Marco Antônio, 28). Ou também o caso de Nero que deixava seus afazeres políticos, os negócios públicos, de lado para deliciar sua alma com o canto e as corridas de biga (SUETÔNIO, Nero, 22-23). Desse modo, a aparência de Augusto 
não se pautava nesses elementos de uma vida baseada no ócio não produtivo, mas sim no de uma ação mais virtuosa em prol da República. Contudo, não deixamos de perceber críticas a hábitos privados de luxo e jogos, como nos apresenta Suetônio. Um único episódio é apresentado pelo historiador romano e põe Augusto em situação complicada que é o caso do 'banquete dos deuses', pois em uma época de carestia, ele se fantasiou de Apolo juntamente com seus convidados, o que lhe provocou a crítica de receber o epíteto de Apolo torturador (SUETÔNIO, Augusto, 70).

Quando observamos o que de um arcabouço cultural estrangeiro pode ser associado a Augusto, acabamos vendo que havia uma preocupação muito mais ideológica que viesse a fundamentar, legitimar sua ação política, criando uma ilusão social que reconfortasse os cidadãos romanos, do que propriamente uma ação que mudasse a forma de jogar a mise en scène da política romana. Um primeiro ponto é buscar ver esses elementos estrangeiros como um 'programa' uniforme de associações ${ }^{48}$. Eles não eram advindos de qualquer lugar, mas sim da Grécia e mais, de seu período clássico $^{49}$, o que nos evita uma associação a alguma realidade monárquica como a das cortes helenísticas, o que também provocaria, talvez, uma alusão a uma pseudo intenção de alteração da forma de se conviver político-socialmente ${ }^{50}$. Assim sendo, o que percebemos é o cuidado empreendido para que esses elementos estrangeiros a serem inseridos durante o momento de principado de Augusto não provocassem um sentimento contrário a elite romana, de que eles serviam apenas como fundamentos do

\footnotetext{
${ }^{48}$ Aqui cabe as aspas, pois não acreditamos que tenha havido um programa completamente fechado de tudo que deveria ser feito e divulgado pelo e a respeito do príncipe. Alguns pontos da cultura material nos parecem sim terem sido pensadas para passarem uma determinada mensagem aos cidadãos romanos, o que colaboraria muito para legitimação e consolidação de Augusto na cena política romana. No entanto, não podemos pensar que havia, como na época moderna, um projeto bem construído, como é o caso de Luís XIV apresentado por Burke em ' $A$ fabricação do rei: a construção da imagem pública de Luís XIV', para que se houvesse uma visão uniforme e condizente com a teatrocracia política de Augusto, até porque a posição de Augusto foi construída aos poucos e constantemente reafirmada em diversos momentos.

${ }^{49}$ Gruen propõe que esses ideais e objetos artísticos eram característicos, grosso modo, da região da Acádia e da ancestralidade troiana (GRUEN, 2006, p.300-302), o que nos mostra também como dentro do próprio conjunto de representação dos povos da região oriental do Mediterrâneo havia uma diferenciação, obviamente que de acordo com as intenções romanas. Schneider analisa essa existência de uma diferença entre as imagens difundidas na época de Augusto que diziam respeito aos orientais, havendo uma clara diferença entre o asiático (troiano) e parto, como é o caso claro da couraça da vestimenta militar de Augusto na sua estátua da Prima Porta (SCHNEIDER, 2012, p.76-129).

${ }^{50}$ De acordo com Davies, os elementos egípcios só foram bem-vistos em Roma quando do butim de Augusto, o que reforçava a supremacia política romana e do conquistador do Egito (DAVIES, 2010, p.354-370). Gruen aponta que os elementos estrangeiros só eram aceitáveis em Roma quando não se tornavam um mecanismo de deturpação dos mores e ameaça do domínio aristocrático. Dois exemplos são bem significativos, o da adoção dos deuses gregos, o que não foi visto com maus olhos, e os cultos a Baco, o que não foi aceito pela elite dirigente romana (GRUEN, 2012, p.343-350).
} 
novo personagem político. Eles deveriam ser absorvidos em conjunto, não apenas impostos unilateralmente $^{51}$.

Um desses referenciais diz respeito à própria ancestralidade da fundação de Roma que ganha muita força em sua época e tem como grande vetor de sua divulgação o poeta Virgílio através da epopéia 'Eneida'. A lenda de que as origens primitivas de Roma não estavam mais ligadas apenas a Alba Longa e ao deus Marte, pai dos gêmeos Rômulo e Remo, é muito significativa. Mas a Enéias, um troiano fugitivo que saiu de sua cidade após a tomada grega e que pelo Mediterrâneo vagou até chegar ao Lácio onde tinha por destino se instalar e estabelecer as raízes de um grande povo, os romanos, é um dos pilares da legitimação de Augusto $^{52}$. No aspecto material da lenda, temos como grande exemplo os painéis da Ara Pacis onde estão representados Enéias, Ascânio e Anquises, o que reforça a ligação da lenda a Augusto, mesmo em um monumento dedicado ao príncipe pelo Senado.

Também devemos destacar o apreço de Augusto por Alexandre. E aqui temos um ponto muito importante para a teatrocracia política. Augusto, bem como parcela da aristocracia romana, tinha aversão ao sistema político monárquico. Contudo, Alexandre era uma figura sempre lembrada pelos romanos. César se comparava ao rei macedônio quando se lamuriava de ter a mesma idade que Alexandre tinha ao ser rei de um vasto território e ele ainda não ter feito nada magnífico para a Urbs (SUETÔNIO, César, 7). Quando da conquista de Alexandria, Augusto teve a oportunidade de prestar suas homenagens ao antigo rei macedônio, indo até seu túmulo, o Sema, ver os seus restos mortais. Como narra Suetônio, ele, porém, foi apenas visitar Alexandre, não se ocupando dos demais monarcas egípcios que eram para ele simplesmente reis (SUETÔNIO, Augusto, 18), o que nos mostra como a figura de Alexandre era estimada e os Ptolomeus vistos de modo inferior. Plutarco nos conta que Augusto, também no momento da conquista de Alexandria, ao proferir o discurso de conquista da cidade e do reino do Egito, no ginásio alexandrino, disse que absolvia o povo egípcio pela traição, ou seja, pela escolha por Marco Antônio e não dele pela disputa do poder político romano, devido, primeiramente, ao fundador da cidade, Alexandre, depois pela beleza

\footnotetext{
${ }^{51}$ Tácito, porém, nos apresenta um quadro não tão favorável aos senadores que aderiram a causa augustana, o que pode nos fazer vacilar um pouco quanto a própria liberdade de absorção desses elementos estrangeiros inseridos por Augusto em seu principado. De acordo com o autor, no que se refere aos senadores, os melhores haviam morrido durante as guerras civis, seja nas guerras, seja nas proscrições, enquanto os outros, ou seja, os 'não-melhores', estes preferiram as vantagens proporcionadas pelo advento do principado de Augusto e a 'paz' do que as turbulências das guerras (TÁCITO, Anais, I, 2).

${ }_{52}$ Cícero, no livro II de 'Sobre a República', ao fazer um retrospecto da história romana, não faz qualquer menção a Enéias ou a essa ancestralidade troiana (CÍCERO, Sobre a República, II, 2), o que para nós pode representar muito mais uma ancestralidade surgida a partir da necessidade de Augusto construir uma visão mítica para as origens de sua linhagem. Plutarco, ao relatar a vida de Rômulo em seu conjunto de biografias, faz uma apresentação de diversas lendas existente em Roma sobre a fundação da cidade (PLUTARCO, Rômulo, 1-2).
} 
dela e, por último, por seu amigo Arrio, seu mestre de retórica em Apolônia (PLUTARCO, Marco Antônio, 103).

Como Pollini argumenta, Alexandre foi imitado não apenas pelos reis herdeiros do Império macedônio, mas também pelos romanos que desde Cipião Africano usaram a referência de Alexandre de diversos modos, como é o caso de Pompeu, Crasso, César e Marco Antônio, por exemplo. O autor destaca a associação que Plutarco faz entre as características físicas de Pompeu e Alexandre e quanto a César o fato do biógrafo ter escolhido o ditador romano como o homem a ser comparado ao rei macedônio em suas 'Vidas paralelas', bem como, no plano iconográfico, a utilização de uma cópia de uma imagem equestre de Alexandre, mas com a cabeça de César, que foi colocada no Fórum Júlio. Pollini insere Augusto nesse conjunto de romanos que buscaram se associar a uma tradição de Alexandre e apresenta diversos exemplos nos textos antigos, mas principalmente na cultura material (estátuas, moedas e construções) que representem essa ligação do herdeiro de César ao rei macedônio (POLLINI, 2012, p.162-190). De acordo com Suetônio, a segunda chancela do príncipe romano foi justamente uma efígie do rei macedônio (SUETÔNIO, Augusto, 50). A própria iconografia de Augusto procurou assemelhá-lo a Alexandre. No entanto, não devemos pensar em uma associação sem riscos, até porque Alexandre não era visto apenas de forma positiva pelos romanos. Como todo homem, ele havia também características negativas, as quais não deveriam ser seguidas, o que nos mostra como havia um filtro sobre aquilo externo que seria divulgado em Roma, havendo sim uma apropriação, mas essa se pautava também em críticas ${ }^{53}$. Pollini aponta que podemos ver Augusto como um apropriador de Alexandre para seu programa ideológico e artístico, enquanto Marco Antônio teria se comportado como Alexandre, ou seja, este último teria sucumbido por tentações e paixões estrangeiras, enquanto o primeiro teria mantido um auto-controle e promovido a restauração da República pela via romana (POLLINI, 2012, p.175-178).

Como Crook muito bem expõe, a grande sabedoria de Augusto foi buscar uma legitimação do seu poder, não se apresentando, como um corpo estranho ao conjunto de

\footnotetext{
${ }^{53}$ Tito Lívio faz uma breve narrativa do rei macedônio. Seu foco é analisar se o seu exército seria capaz de ganhar do exército romano. No entanto, ao fazer essa reflexão, ele nos apresenta alguns elementos de retrato de Alexandre. $\mathrm{O}$ autor romano aponta que, apesar da força macedônia, os romanos eram superiores devido ao fato do poder e o exército macedônio estar apenas estruturado ao redor do rei, não em homens virtuosos como no caso da República romana. Ou seja, uma crítica ao poder de um só homem. Tito Lívio também argumenta que Alexandre não era um bom exemplo de governante por ter assimilado a si e ao seu governo muitos elementos da cultura persa como os trajes, o fausto e a adulação (TITO LÍVIO, História Romana, IX, 17-19). Pollini argumenta que Augusto se colocou como superior a Alexandre justamente por saber dotar a conquista romana no Mediterrâneo de uma estrutura de governo e de uma paz, além de não ter adotado os costumes estrangeiros, o que não foi o que o rei Macedônio fez (para a realidade asiática) ou, talvez, Marco Antônio teria feito (POLLINI, 2012, p.178).
} 
cidadãos da República (CROOK, 2001b, p.117). A sua supremacia na cena política romana é evidente, ainda mais quando tomamos os relatos posteriores ao seu governo, quando já da vivência pelos romanos do Principado. No entanto, no decorrer de sua ação política, ele precisou se reafirmar constantemente no seio da teatrocracia romana. Assim, analisar o comportamento social do príncipe, bem como os relatos propriamente de sua época, nos é importante, pois é um elemento crucial na sua legitimação como o princeps senatus.

Um ponto importante no comportamento social de Augusto é a simplicidade de seu porte e de suas roupas ${ }^{54}$. Augusto não buscou expor sua diferença com relação aos cidadãos da Urbs através de trajes suntuosos, divertimentos escandalosos ou com a construção de um palácio, pois ele já detinha outros meios para a explicitação de sua auctoritas em outros suportes para além de sua própria pessoa e escolheu outros elementos, como dito, que não se ligassem apenas a sua pessoa, como era, por exemplo, o fausto de Cleópatra em Tarso e de Marco Antônio em Alexandria. O que, porém, não o impedia de usar elementos que o diferenciassem socialmente dos demais. Segundo Scheid, Augusto recebeu progressivamente o direito de portar os elementos triunfais em sua vida pública como a roupa triunfal, a coroa de louros (36 a.C.), a coroa triunfal de ouro (29 a.C.), a toga triunfal (25 a.C.), a toga pretexta, bem como assentos especiais, ser precedido por 12 lictores (19 a.C.) e afixar no exterior de sua casa símbolos como a corona civica, o clupeus virtutis e coroas de louro triunfais (SCHEID, 1990, p.40-41). O que prevaleceu foi o bom-senso de quando usar cada marca distintiva de sua posição, o que muito casava com o seu discurso de restauração da República, pois reviver os costumes dos antepassados, que acreditava-se estarem em desuso, era propriamente voltar a um determinado passado, em que a coletividade fosse a base da própria estruturação das relações sociais e que a simplicidade fosse uma prática.

Desse modo, uma primeira ação nessa direção pode ser observada através dos poetas ligados a Mecenas. Virgílio e Horácio muito cantaram as simplicidades dos varões do passado através da exaltação de suas virtudes camponesas. Portanto, o plano de moralização desempenhado sob a tutela do príncipe prescindia desse retorno às boas virtudes romanas.

Outro ponto é a própria valorização da principal unidade social romana, a domus ${ }^{55}$. A domus era o espaço em que as relações sociais mais básicas se constituíam e onde a educação

\footnotetext{
${ }^{54}$ Wallace-Hadrill trata desse ponto quando aborda a característica de privatus dos príncipes romanos.

${ }^{55} \mathrm{O}$ uso da palavra família no presente trabalho se distancia do verdadeiro sentido que ela detinha entre os romanos. Para os romanos, a domus que representava o que hoje denominamos como família, pois esse termo dizia respeito às pessoas ligadas por laços de parentesco. Assim, a domus Augusta dizia respeito aos familiares do príncipe. Já o termo familia denominava não só as pessoas, mas também toda a estrutura material daquele círculo familiar, ou seja, englobava as pessoas, os objetos da casa e/ou de produção e os escravos. O pater famila
} 
do que era ser romano se iniciava para os jovens aristocratas. Era um espaço em que a Religião romana estava presente. Isso sem contar que ela era o suporte para o estabelecimento de emaranhamentos sociais através dos laços matrimoniais entre seus membros. As ações na esfera da domus, a esfera privada, tinham grande repercussão na esfera pública, a ciuitas.

Augusto também se utilizou de sua domus como um de seus pilares políticos. O fato de Suetônio apontar que Augusto usava roupas feitas em casa (SUETÔNIO, Augusto, 73) já eleva as virtudes das mulheres de sua domus, pois elas estavam ligadas aos trabalhos domésticos, considerados por sua excelência femininos, estando, consequentemente, longe da esfera política, exclusivamente um papel masculino, até porque as mulheres não tinham direito de ação no campo eleitoral romano, um espaço de ação apenas dos homens. Desse modo, ele eleva os membros de sua domus a exemplos para os demais da República. Até porque, não podemos deixar de reforçar que com o advento do Principado temos a elevação da domus do príncipe sobre as demais, primeiro pela auctoritas de Augusto, segundo pela elevação de seus membros as honras romanas e suas ações em prol da República. Mesmo ele se colocando como um exemplo a ser seguido (Res Gestae, II, 8), não podemos argumentar que isso tenha sido consensual e que ele tenha conseguido moralizar toda a sociedade romana. Dois casos que podemos dar. O primeiro diz respeito aos desvios cometidos pelos príncipes sucessores de sua própria domus, como é o caso de Tibério, Calígula e Nero. Um segundo exemplo, mas mais complexo é o de sua filha Júlia que foi condenada ao exílio por adultério, sendo um desvio moral considerado um grande crime e uma afronta ao próprio exemplo que seu pai queria dar a sociedade romana. Contudo, este é um exemplo complexo, pois a falta de moral de Júlia pode ser considerada como uma desculpa dada a uma ameaça de conspiração contra Augusto, porém, o fato dessa ter sido a justificativa do desterro da filha uma informação muito instigante, visto ser uma acusação de desvio moral o suficiente para excluir socialmente algum membro da ciuitas romana.

Desse modo, diferentemente do que vimos anteriormente quando da apresentação das acusações proferidas contra Marco Antônio, em que seus hábitos eram sempre excessivos, tanto quanto ao álcool, quanto com relação aos banquetes, por exemplo, e que a si ele havia associado deuses como Baco ou mesmo adotado alguns costumes egípcios, como nos apontam alguns autores, Otaviano/Augusto procurou sempre manter a sua figura mais neutra, a não ser quando nos referimos a Apolo, e se colocar enquanto uma das peças que compunham o cenário geral do Principado. Ele era também um dos elementos que compunha 
a teatrocracia, como seus discursos (o de auto-valorização e o de depreciação de seus opositores), cargos e símbolos também o eram. Assim, tudo está inserido dentro desse quadro geral que é o da implantação, legitimação e manutenção do Principado augustano.

Retomando, Wallace-Hadrill argumenta que a condescendência para com os demais era um dos caminhos para se fugir da fragilidade da posição dos autocratas. Aristóteles aponta que o ódio e o desprezo põem o monarca (governante) em perigo, pois são elementos que geram grande insatisfação popular ou, pelo menos, de alguns setores sociais em especial. Assim, o governante deve então mascarar sua fragilidade humana, criando uma espécie de escudo protetor, e se apresentar maior do que todos os demais, porém, dentro de certos limites (WALLACE-HADRILL, 1982, p.33).

Dentro dessa teatrocracia que permeia o principado de Augusto, outros aspectos que devemos observar da encenação social do príncipe são os símbolos de poder, os cargos, as honras e os poderes do príncipe como elementos manipulados por ele com o objetivo de construir sua ação política, como suportes para a sua encenação da restauração da República, e a sua imagem. Todos devem ser vistos como elementos de sua auctoritas e importante para esta.

\section{Cargos, poderes e honras de Augusto}

Como já apontado, o Principado romano não foi fruto de uma cartilha completa apresentada por Augusto ao Senado e ao povo romano em 27 a.C. com a descrição de quais deveriam ser suas funções junto ao corpo civil e militar da República nos próximos anos. Muito pelo contrário. Augusto teve que, a cada fase de sua ação política, buscar se reafirmar na posição de destaque do cenário político romano. A cada momento de crise, fraqueza, oposição ou distanciamento da Urbs o príncipe teve que se legitimar como um bem-feitor, como um homem preocupado com o bom funcionamento da República. Desse modo, a cronologia do principado augustano deve ser analisada como um reafirmar de Augusto em sua posição. A sessão de 27 a.C. pôs o príncipe em uma posição de destaque e de conforto com relação aos demais cidadãos de Roma, mas não o permitiu ficar por completo apenas aproveitando os louros de sua vitória em Actium ou as honras advindas desse episódio. Augusto teve que constantemente provar ser merecedor de sua posição de destaque, até porque sua ação política de restauração da República se desenvolveu em etapas e campos de ação por diversas fases de seu governo. Assim observamos o porquê das ações legislativas 
serem tardias, bem como em determinados momentos parecer não haver uma ação tão efetiva de Augusto. Outro exemplo de que o Principado era um acontecimento em andamento é a própria forma de associação de outras pessoas ao sistema de honras romano, principalmente ligadas a domus Augusta, para que a estrutura que Augusto estava estabelecendo em Roma se perpetuasse, fazendo com que o príncipe buscasse associar outros homens a sua causa, ou seja, ao bem-estar da República, como é o caso de Marcelo, Agripa e Tibério, por exemplo.

É dentro desse contexto da constante necessidade de se reafirmar na posição de destaque da cena política romana que devemos analisar os cargos, as honras e os poderes de Augusto. A teatrocracia do mundo romano pressupunha isso e o discurso de restauração republicana de Augusto fazia como que ele também precisasse se mostrar perante aos romanos como um homem da República, um homem que não tinha excepcionalidade nenhuma além dos demais e que deveria ter constantemente renovadas suas magistraturas e seus poderes (imperium proconsulare e tribunicia potestas), visto na República todos os cargos públicos serem regidos por mandatos. O próprio argumenta, "vi-me à frente de todos pela autoridade (auctoritas), mas nenhum poder tive a mais do que meus outros colegas também investidos de cargos" (Res Gestae, VI, 34), no entanto, a sua posição de liderança perante os demais é indiscutível ${ }^{56}$. Ora, foi a ele que recorreram os reis que desejavam estreitar os laços de aliança ou firmar algum tratado de paz com os romanos. Isso nos mostra uma deturpação da constituição romana como descrita por Políbio no século II a.C.. Os assuntos externos eram de incumbência do Senado, não dos cônsules ou de qualquer outro magistrado (POLÍBIO, Histórias, VI, 13). Foi ao Senado romano que recorreram os vários reis egípcios durante suas querelas pelo trono alexandrino, e mesmo quando Ptolomeu Aulete buscou Pompeu e César como apoio devido a sua delicada situação dinástica, vemos as discussões se darem no interior do Senado, não numa ação deliberativa pessoal de um dos dois triúnviros. Mas o próprio príncipe afirmar sua excepcionalidade seria um ato de deturpação da República. A ilusão social era importante e foi dentro desse campo que Augusto agiu ao mascarar sua supremacia política. Como não se lembrar de Cipião Africano e as três fases de sua ação política em que da apoteose ele foi até a expulsão do cenário político romano considerado como um mal à República? (SEBASTIANI, 2007, p.91-96).

No entanto, as próprias fontes da época, como apontam Crook (2001b) e Millar (1973), apresentam muitas dificuldades aos historiadores atuais a compreenderem os reais

\footnotetext{
${ }^{56}$ Sobre seus poderes, Augusto em suas res gestae escreve que foi 13 vezes cônsul, que foi por 10 anos triúnviro, que esteve durante 37 anos investido do poder tribunício (Res Gestae, I, 4), além de ter sido durante 40 anos princeps senatus (Res Gestae, I, 7), isso até o momento em que escreveu sua res gestae, de acordo com o próprio.
} 
poderes de Augusto, seja no Triunvirato ou no próprio Principado, pois as questões que elas se propunham a responder eram diferentes daquelas com as quais as questionamos atualmente. Sabemos da posse do imperium proconsulare e da tribunicia potestas, algo que o próprio príncipe apontava em suas representações numismáticas, por exemplo, mas maiores detalhes sobre atribuições e limites não nos são informados. Contudo, mais importante do que saber de fato esses detalhes, para nós, como alguns historiadores têm argumentado, como é o caso de Crook (2001b) e Galinsky (1996), é essencial saber como ele articulou toda a sua ação política. Isso não seria possível apenas possuindo determinados poderes. Há algo além.

A historiografia atual tem se baseado muito nas próprias palavras de Augusto em suas res gestae. A auctoritas do príncipe tem sido um elemento muito abordado e considerado de fato como seu principal instrumento de ação na cena política romana durante a implantação do Principado. Um termo que envolvia questões morais, políticas, sociais e que foi utilizado como suporte em diversas representações do príncipe. Galinsky faz uma análise sobre a importância da escolha de Augusto por esse termo em suas res gestae e demonstra como a auctoritas the conferia uma superioridade moral, apesar de a potestas ser seu principal poder, sobre os demais romanos, o que tinha uma grande força política, social, religiosa e legislativa e como ela foi expressa em outros suportes, como o literário, o caso de suas referências na 'Eneida', e iconográfico, caso de suas moedas e da Prima Porta, por exemplo (GALINSKY, 1996, p.9-41). Ora, ele era superior aos demais através de uma honra, não possuindo o controle total do jogo político, sendo mais um dos demais magistrados, grosso modo, da República. Além de ser uma autoridade construída ao longo do tempo, não adquirida de uma única vez. Para o entendimento da mise en scène, a escolha e análise desse termo pelo próprio príncipe são cruciais.

Outro elemento importante para a análise da encenação de Augusto é o próprio título que ele adota quando da sua atuação política. Ele não era um rex ou um dictator, mas sim o princeps senatus. Ele aqui não estava na posse de nenhuma magistratura, mas sim ostentando um título honorífico, o de primeiro dos senadores, pois ele era um membro da ordem senatorial como os demais senadores também o eram, mas com distinções no campo das honras. Para nós, é interessante observarmos como ele se apresenta como príncipe, reforçando uma posição de diferença, em suas res gestae ele aponta essa posição por ele ocupada quando da apresentação do fechamento dos portões do templo de Janus (Res Gestae, II, 13), o que por si só já é uma grande honra para os investidos em magistraturas e senadores. Augusto marca sua ação política na cena romana não como o possuidor de uma magistratura, como o consulado, por exemplo, mas com um título que abarca um espaço temporal maior, 40 anos, 
de 27 a.C. a 14 d.C., e que não fere a estrutura republicana por completo, Cipião Africano e Cícero, por exemplo, haviam possuído a mesma honra de ser princeps senatus. Ele marca sua distinção, sinalizado através da posse do título de princeps senatus, o qual o catapultava para a ponta de destaque da cena política romana, mas não se apresenta como um corpo estranho à República.

Sendo Augusto um homem da época de Cícero, não podemos deixar de pensar que este orador tenha influenciado o então jovem daquela época e já experiente de anos depois, na sua escolha por alguns elementos do comportamento social, como é o caso adoção da honra de princeps senatus como um grande adereço em sua ação. Em 'Sobre a República', Cícero faz alguns apontamentos sobre as constituições e argumenta qual seria a mais adequada após a constituição mista da República romana:

\footnotetext{
"[Eu escolheria - aqui Cícero usa Cipião como personagem para tal fala] a monarquia [como a melhor das três formas de governo] desde que o título de pai (pater) fosse sempre inseparável do de rei (rex), para expressar que o príncipe (princeps) vela sobre seus concidadãos como sobre seus filhos, mais cuidadoso de sua felicidade do que da própria dominação, dispensando uma proteção aos pequenos e aos fracos, graças ao zelo desse homem esclarecido, bom e poderoso" (CÍCERO, Sobre a República, I, 35).
}

Podemos pensar que analisando o contexto conturbado de guerra civil romano e restituição da República, Augusto possa ter se inspirado, mesmo que não completamente, nos dizeres de Cícero para adoção do título e das ações do princeps senatus, visto serem contemporâneos e os escritos do orador romano o pilar de um grupo aristocrático, o mais conservador da República, que justamente temia uma corrupção dos mores.

Desse modo, temos um homem que agiu enquanto um homem público romano, através de sua posição de primeiro dos senadores, princeps senatus, e por sua auctoritas, mais do que por qualquer cargo em que fosse investido, como seus consulados, por exemplo. Essa mise en scène foi muito importante para Augusto, tanto que em 2 a.C. ele recebeu mais uma honra, o título de pater patriae, o qual ele colocou como a última de suas honras e, assim, uma das mais importantes, quando escreveu suas res gestae (VI, 35). A ação política de Augusto, então, pode ser vista como uma excepcionalidade, algo possível pelo próprio momento de adaptação pelo qual a Urbs estava passando, sendo o principado de Augusto uma espécie de experimentação, como Galinsky gosta de denominar (GALINSKY, 2012, p.61-83). No entanto, uma ação que, como já abordado anteriormente, tinha seus limites e aspectos políticos. 
Trazendo mais diretamente para nosso paralelo analítico, que são as realidades monárquicas, Augusto precisou tomar cuidado com a criação de sua imagem, o que tangenciava diretamente a forma como ele recebia as honras, ocupava os cargos e recebia e concentrava poderes de ação. Se ele se dizia restaurador da República contra uma ameaça de dominação tirânica ou monárquica, ele não poderia ser justamente um exemplo desse tipo de atuação política. Assim, mais do que apenas agir de acordo com os moldes dos antepassados romanos, era preciso reforçar o pacto com a Urbs e se mostrar diferente dos rivais, o que pressupunha uma ação em acordo com o seu discurso, o qual podemos ver em suas res gestae, em prol da coletividade e com outros magistrados agindo conjuntamente.

$\mathrm{O}$ rei helenístico era um homem que detinha um grande poder absoluto, em esferas como a militar, a burocrática, a judicial, a religiosa e era o homem mais rico do reino. Augusto não deixou de ser o homem mais proeminente nesses setores, mas precisou mostrar que não era somente ele quem agia na cena política romana e que suas ordens ditavam as ações dos magistrados romanos nesses campos.

\section{Os símbolos do poder augustano}

Os símbolos de poder de Augusto eram, na verdade, os símbolos que demarcavam a sua principal vitória, Actium, e as suas honras recebidas no decorrer de sua ação como homem político. Sua vitória sobre seu rival, além de permitir que ele se consolidasse como o principal expoente possível de restaurar a República, dotou Augusto de grandes honras como um triunfo triplo, em 29 a.C., ao retornar de Alexandria. Entretanto, como Zanker argumenta, ele não pôde fazer claras referências ao derrotado, pois os filhos de Marco Antônio continuaram pertencendo a sua domus, visto o fato de Otávia, sua irmã, ter se casado com o seu rival de Triunvirato e depois da morte dele em Alexandria, após a derrota de Actium, ter cabido a ela a tutela dos filhos gerados no casamento (Antônia Maior e Antônia Menor) e dos outros filhos de Marco Antônio (PLUTARCO, Marco Antônio, 110). Como também o fato de os partidários de Marco Antônio serem cidadãos romanos, não inimigos estrangeiros, como a rainha do Egito, ou seja, terem de ser reinseridos na lógica de funcionamento da República (ZANKER, 1988, p.82) ${ }^{57}$. Outro ponto que devemos ressaltar é o fato de que também não seria interessante para Augusto, logo após a vitória de Actium, construir todo um discurso

\footnotetext{
${ }^{57}$ Zanker faz uma análise sobre os edifícios públicos da época de Augusto e mostra como a batalha do Actium foi um tema recorrente nas alegorias que compunham a ornamentação de tais espaços, como a Cúria Julia, o templo de César e o templo de Saturno, por exemplo. Cf: ZANKER, 1988, p.79-85.
} 
contrário à rainha estrangeira como principal suporte de seus símbolos de poder. O Egito era uma importante província, tanto econômica, quanto estrategicamente falando, o que poderia dificultar o estabelecimento de uma relação entre os romanos e os egípcios, agora incorporados ao império do povo romano, importantes para o estabelecimento das raízes imperiais em toda a bacia do Mediterrâneo ${ }^{58}$. Com isso, observamos que em relação à sua vitória em Actium, seu discurso se prendeu muito mais em seus próprios feitos do que na diminuição sistemática dos rivais, o que não quer dizer que não tenha havido a circulação de mensagens difamatórias. Elas, no entanto, deveriam ser mais sutis.
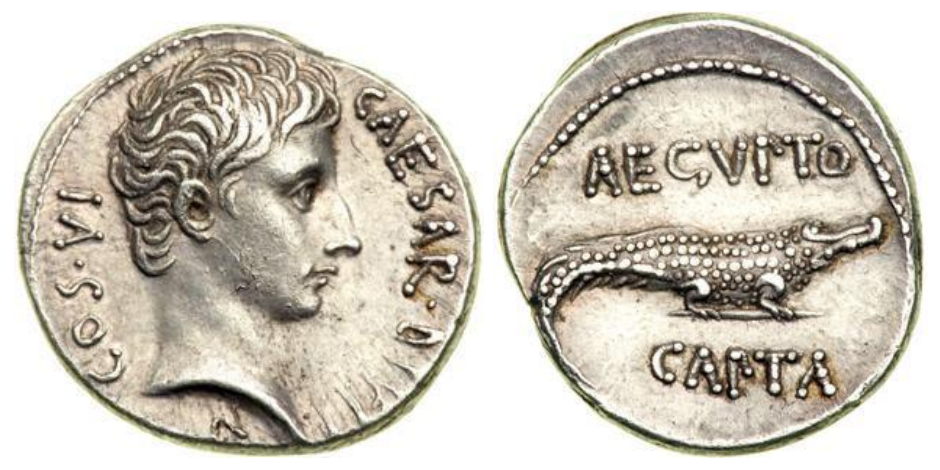

Imagem 7 - Moeda de Augusto em homenagem a conquista do Egito (RIC 0545); - denário de prata; - cunhada entre 28 e 27 a.C.;

- Anverso: CAESAR COS VI - cabeça de Augusto; - Reverso: AEGYPTO CAPTA - crocodilo;
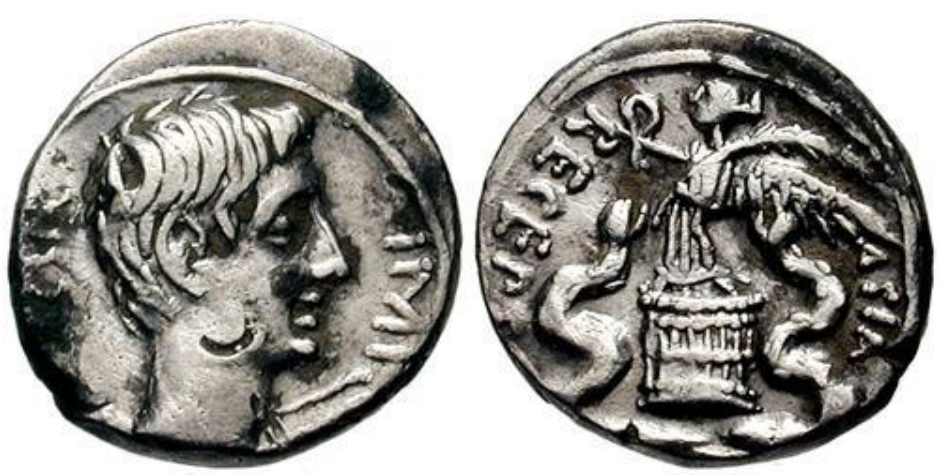

$\underline{\text { Imagem }} \underline{8}$ - Moeda de Augusto em homenagem a reconquista da Ásia (RIC 0276); - quinário de prata;

- cunhada entre 28 e 26 a.C.;

- Anverso: CAESAR IMP VII - cabeça de Augusto;

- Reverso: ASIA RECEPTA - Vitória sobre uma cista;

\footnotetext{
${ }^{58}$ Huzar faz uma análise de como Augusto empreendeu sua dominação do Egito logo após o reino ser anexado ao conjunto de províncias romanas por ele, em 30 a.C.. A autora demonstra como o general romano buscou se utilizar das próprias estruturas do reino dos Ptolomaicos como suporte para a imposição da dominação romana, isso nas esferas política, religiosa, jurídica, militar e econômica. Cf: HUZAR, 1988, p.343-382.
} 
Como exemplo, podemos observar as duas peças numismáticas acima representadas. Augusto as mandou cunhar em 28 a.C. (o que as torna muito significativas nesse ponto, pois ele devolveria seus poderes especiais a República no ano seguinte), uma em homenagem a conquista do Egito (AEGYPTO CAPTA) (Imagem 7) e outra em homenagem a reconquista da Ásia (ASIA RECEPTA) (Imagem 8). Ambas são comemorações de feitos de Augusto em prol da República, mas em oposição a Marco Antônio, que era casado com a rainha do Egito e detinha a posse das terras orientais da República romana, ao menos anteriormente pelo acordo do Triunvirato, que, no entanto, haviam sido doadas para os filhos da rainha do Egito, nas chamadas Doações de Alexandria, em 34 a.C.. Ou seja, temos através desses dois objetos Augusto reforçando que ele era o único na cena política romana e que havia recuperado territórios doados ilegalmente a um reino estrangeiro, o que é o caso da província da Ásia, e também conquistado esse reino para o povo romano, o Egito.

Desse modo, no que concerne a 'ataques' a Marco Antônio e Cleópatra, a necessidade de sutileza de Augusto nos mostra como ele não era tão poderoso no interior da cena política romana e como, apesar da construção de um discurso contrário aos rivais, ele teve que saber como mobilizar os referenciais e os acontecimentos de sua época para fazer a transmissão de suas mensagens. Isso nos reforça como a auctoritas de Augusto foi sendo construída e reafirmada constantemente, mas sem confrontos diretos a memória dos rivais, mesmo tendo ocorrido uma batalha entre os dois antigos triúnviros. A cena política era movida pelo drama e pela ilusão, mas havia certos limites e critérios a serem seguidos.

Quanto aos próprios símbolos de Augusto, temos, primeiramente, aqueles que ele próprio cita em suas res gestae, a corona civica, o clupeus uirtutis e o título de Augustus, elementos que ele recebeu como honras devido a sua ação em prol da República e os quais contribuíram para que ele se elevasse na cena política romana por sua auctoritas (Res Gestae, VI, 34). Também podemos considerar outras honras como símbolos de Augusto e as quais foram ostentadas pelo príncipe, como, por exemplo, o fato de ser o diui filius, o cargo de princeps senatus e pontifex maximus ou o título de pater patriae.

Para os romanos, o principal símbolo de poder das monarquias era o diadema. Ele era um elemento sempre presente nos retratos e nas peças monetárias dos reis helenísticos, como podemos observar nas representações dos reis e rainhas do mundo oriental, inclusive Cleópatra.

Na história romana muitos são os exemplos dos episódios lembrados pelos autores antigos em que um romano está com um diadema. Entretanto, todos são apresentados sob o prisma moral, algo característico da própria tradição literária romana. Assim, os episódios que 
envolvem os diademas possuem sempre um traço negativo, como a apresentação de uma ação contrária ao sistema republicano, que atacava o bom funcionamento dos negócios públicos romanos. Suetônio nos apresenta alguns desses casos. Um deles, ao fazer um retrospecto sobre os maus membros da domus Cláudia, é o caso de Cláudio Druso, que havia mandado erguer no Fórum uma estátua sua portando o diadema (SUETÔNIO, Tibério, 2). O autor também cita o caso de Calígula quando de uma embaixada de reis estrangeiros em Roma em que, após gritar que houvesse então apenas um chefe, no caso ele, "por pouco não tomou o diadema, substituindo assim, a aparência de principado pela forma de realeza" (SUETÔNIO, Calígula, 24).

Um episódio sempre lembrado pelos autores antigos é o de Marco Antônio e César na festa da Lupercália, em Roma, em 44 a.C., em que, segundo as fontes, Marco Antônio teria tentado colocar um diadema na cabeça de César, mas este, no entanto, teria se recusado a receber o adereço, o que causou uma onda de aplausos, e mandado enviar o objeto ao templo de Júpiter (PLUTARCO, Marco Antônio, 16; César, 79; SUETÔNIO, César, 79) ${ }^{59}$. Cícero também faz uma menção ao episódio em seus discursos contra Marco Antônio. Ele argumenta que ao tentar colocar um diadema na cabeça de César, Marco Antônio abdicava não só de seu consulado, mas também de sua liberdade, e continua, "eu veria um cônsul, um cidadão romano, um homem livre então naquele que, num dia de honra e de baixeza, mostrou o que, César vivo, poderia sofrer, e o que, César morto, ele ousaria ambicionar para si mesmo?" (CÍCERO, Filípicas, III, 5). O discurso de desejo monárquico a Marco Antônio aparece apenas neste breve trecho das 'Filipicas', porém, não deixa de ser expressivo o temor da monarquia junto de uma parcela romana da sociedade ${ }^{60}$.

Mais um exemplo é interessante. Remetemo-nos ao presságio apresentado por Tito Lívio sobre a pré-destinação de Tarquínio Prisco a Realeza. O rei, antes de ser entronado, teve um presságio com um círculo de fogo ao redor de sua cabeça. O que nos reforça esse destaque de um elemento ligado a cabeça como elemento real (TITO LÍVIO, História Romana, I, 34), ainda mais pelo fato desse relato ser contemporâneo a Augusto.

Os reis romanos não são descritos pelos autores do século I a.C. como possuidores de elementos distintivos da monarquia. Pela própria natureza dos relatos, que buscam muito mais

\footnotetext{
${ }^{59}$ Dentro da biografia de Suetônio sobre César, este é um dos episódios que demonstram um comportamento de César pró-realeza. Traço também perceptível na biografia de Plutarco sobre o mesmo personagem romano.

${ }^{60}$ Aqui digo parcela por que essa acusação de Cícero deve ser muito bem entendida dentro do contexto em que se insere seus discursos contra Marco Antônio. Ele queria ferir a imagem do antigo cônsul depois de ter tido uma pequena desavença com ele. Contudo, Cícero não admite algumas ações de Marco Antônio contra Bruto e assim, cada vez mais, faz acusações com relação à ameaça que Marco Antônio viria a ser a libertas republicana. O que não é levado em consideração por todos os senadores, como podemos ver pelas ações tomadas pelo Senado na querela entre Bruto e Marco Antônio pela posse da Gália Cisalpina.
} 
ver as 'raízes' do sistema republicano na época da Realeza do que propriamente apresentar uma história 'fidedigna' dessa fase do passado romano, os autores acabam se preocupando em analisar a existência ou não do aval popular ou as medidas que permitiram o surgimento da República. Tito Lívio aponta poucos elementos característicos do personagem político real (TITO LÍVIO, História Romana, I), sendo o comportamento social dos reis com os demais setores sociais mais importante do que seus próprios elementos distintivos. Já Cícero, quando aparentemente em sua narrativa sobre os reis romanos em 'Sobre a República' iria tocar no assunto dos símbolos monárquicos, seu texto se torna uma lacuna, não tendo sido legado a nós pelo tempo (CÍCERO, Sobre a República, II, 25).

Os romanos utilizavam outro elemento como forma de coroa. Não uma coroa de metal precioso que colocava o seu possuidor acima dos demais apenas pela sua posse material. Para os romanos a simbologia era outra. $\mathrm{O}$ direito de posse desse objeto distintivo e assim, o direito de poder ostentar a sua posse, que era de fato importantes para os romanos. A estrutura aristocrática romana, ao menos em teoria, valorizava o mérito pessoal de seus membros em ações em prol da República. O destacamento em ações coletivas devido a características pessoais que era importante para os romanos ${ }^{61}$. Algo característico de uma sociedade em que poucos detinham, de fato, o poder. Desse modo, era a meritocracia que geria o sistema de honras romano. Obviamente que observamos desvios a essa regra. Muitos aristocratas ganhavam honras apenas por terem um bom nascimento ou terem posses.

A coroa utilizada entre os romanos seguia essa lógica meritocrática. Ela era um símbolo com uma conotação semelhante aquela da Grécia onde era utilizada com o fim de coroação aos grandes feitos dos atletas nos jogos em homenagem a Zeus, as Olimpíadas. Os atletas vitoriosos desse grande momento festivo e de paz, visto que durante os dias de acontecimento dos jogos Olímpicos era selado um tratado de trégua entre as partes beligerantes. Assim como era uma grande honra ser um campeão olímpico, era uma grande honra possuir essa coroa perante os romanos, tanto que todos que a possuíam faziam questão de reproduzir estátuas e peças monetárias portando-a. Falo aqui da coroa de louros, que no caso grego era feita de ramos de oliveira. Diversos são os exemplos de casos em que Augusto se apresenta portando a coroa de louros. A primeira vez em que ele pode portá-la foi após a sua vitória, em 36 a.C., contra Sexto Pompeu, quando recebeu a honra de imperator.

Após a sessão do Senado de janeiro de 27 a.C., como o próprio bem aponta em suas res gestae, ele teve colocada sobre os umbrais de sua casa uma corona cívica (Res Gestae, VI,

\footnotetext{
${ }^{61}$ Não há como não se lembrar de Cícero exortando os varões ilustres que elevaram a glória romana devido aos seus valores, as virtudes (CÍCERO, Sobre a República, V, 1).
} 
34). Essa coroa mais do que apenas algo colocado sobre sua cabeça, mas sobre a sua porta, diante da qual os transeuntes poderiam passar e contemplá-la, foi dada a ele por mérito pessoal em um momento muito importante na teatrocracia política. Fragmentos encontrados no sítio arqueológico de seu mausoléu comprovam que na parte exterior do monumento, perto da entrada principal, ao lado das placas de bronze onde estavam transcritas as res gestae, ou seja, acessível ao olhar de todos aqueles que passeavam pelo Campo de Marte, havia a representação dessa corona cívica como um dos elementos de ornamentação de seu mausoléu. Mas muito mais do que apenas um simples ornamento, devemos encarar a presença da representação dessa coroa no conjunto de seu mausoléu como um elemento do conjunto. Importante assim como os demais, pois todos procuravam passar uma mesma mensagem sobre o príncipe, e nada melhor do que os símbolos do poder de Augusto em seu mausoléu para isso.

Abaixo temos alguns exemplos iconográficos de Augusto portando essas coroas. Os dois primeiros bustos (Imagens 9 e 10) são muito significativos pelo fato do príncipe procurar utilizar um material como o mármore para representações suas portando os símbolos. Não nos cabe aqui discorrer a respeito das características do retrato de Augusto, as quais reforçam, no entanto, a intenção de representação, e sim a posse dos símbolos e o intuito de transmiti-los a posteridade, de se perpetuar uma memória. Mais do que isso também, é o de se fazer representar com as coroas cívicas e de louro ao invés de um diadema, o que reforça que sobre sua cabeça estavam símbolos romanos que o tornava igual a todos, mas diferente nas honras. Com relação às moedas, também observamos como Augusto busca transmitir a posse desses símbolos.

Desse modo, numa análise de conjunto, é muito interessante ver a reprodução das coroas de Augusto. A posse delas não significava, necessariamente, que todos os seus retratos tinham uma representação desses objetos, ou seja, Augusto sabia quando não fazer uso de tais símbolos. Nas imagens 7 e 8, temos o seu retrato totalmente destituído de adereços. Ele aqui sabia que a apresentação de sua efígie sem qualquer elemento que o fizesse parecer diferente dos demais senadores era o mais adequado, mesmo já tendo realizado seu triunfo de 29 a.C., o que mostra como apesar da posse da coroa de louro, a prudência e o respeito à ciuitas eram mais importante. 


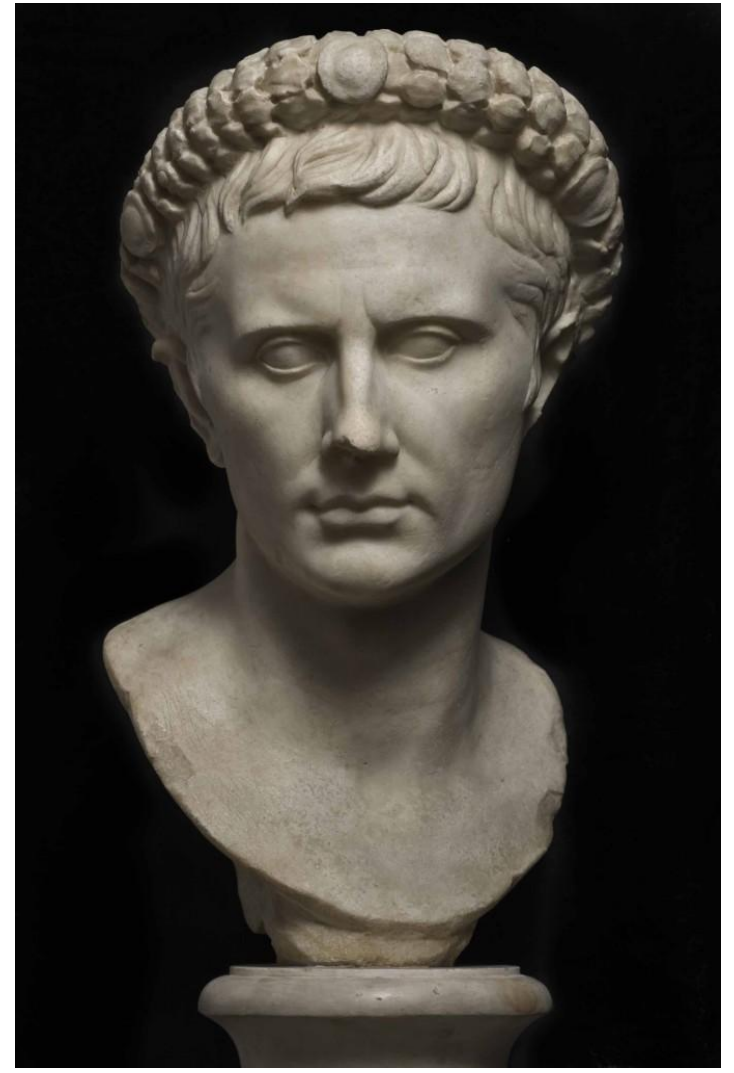

$\underline{\text { Imagem }} \underline{9}$ - Augusto com a coroa cívica; - busto em mármore;

- Museu Capitolino (Roma - Itália);

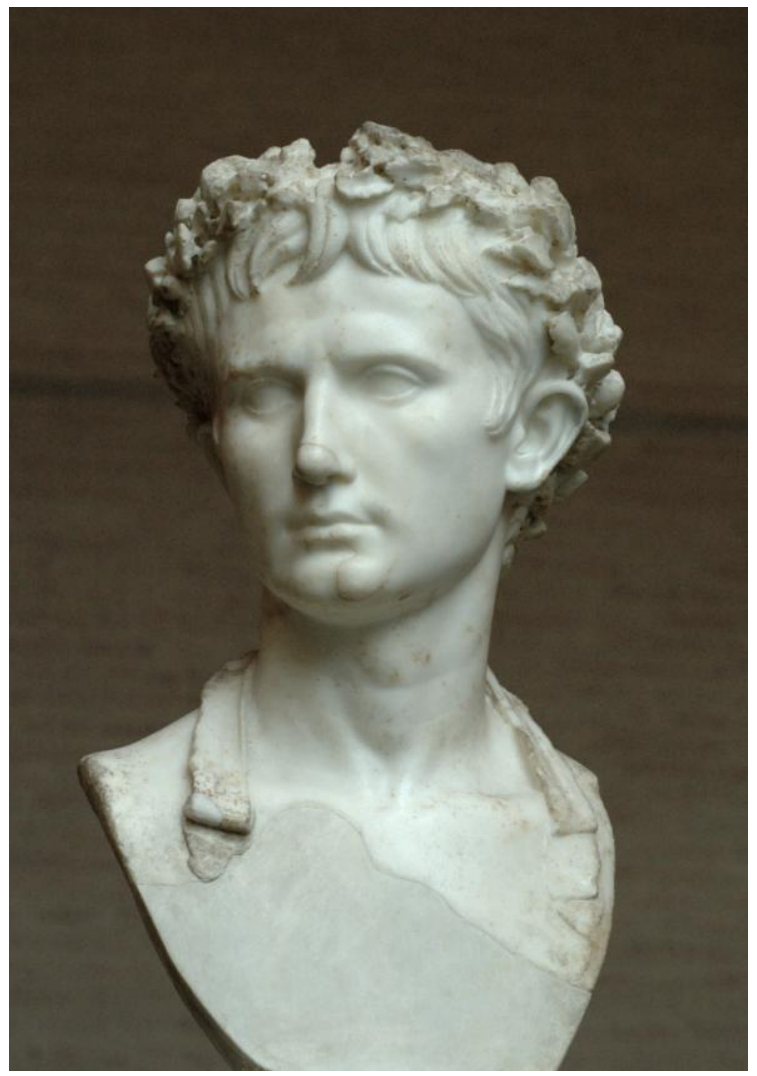

$\underline{\text { Imagem }} \underline{10}$ - Augusto com a coroa de louros; - busto em mármore;

- München Glyptothen - Staatliche

Antikensammlungen (Munique - Alemanha);

A corona civica e a coroa de louros também foram recorrentes nas representações numismáticas de Augusto (Imagem 6), o que demonstra como foram elementos sempre mobilizados nessa criação da áurea do Principado e de reforço das boas ações do príncipe. A coroa de louros foi representada sendo portada por Augusto, como em associação com outros elementos que compuseram o plano simbólico do príncipe.

Tratamos como símbolos de poder de Augusto esses objetos, pois o governo dos Césares, como aponta Suetônio, não possuía qualquer símbolo de poder (SUETÔNIO, Tibério, 15), isso para não recorrer a termos como 'monarquia' ou 'governo individual', o que não compreendem totalmente a ambiguidade da posição de Augusto. A posição de Suetônio é interessante, visto ele reforçar a não utilização de elementos característicos de um governo pessoal, como é o caso do diadema, pelos príncipes romanos. Contudo, ele não observa, devido talvez ao seu olhar aristocrático, como algumas das honras, concedidas pelo povo e pelo Senado, como havia de ser na República, visto o príncipe ser apenas o primeiro dos senadores, se tornaram elementos distintivos e legitimadores de um poder. A corona cívica, 
que é mais do que uma comum coroa de louros oferecida a outros romanos, é um desses elementos. Ela possui uma carga simbólica distintiva tão grande quanto o diadema. Augusto soube se utilizar de um elemento romano, mas que permitia uma dupla leitura: a de que ele estava no topo da linha honorífica-meritocrática da República e que ele não estava fazendo uso de um elemento distintivo estrangeiro, o que por oposição reforçava uma ação em prol da República.

Entretanto, cabe uma breve consideração sobre Marco Antônio aqui. Não observamos no conjunto de imagens do antigo triúnviro nenhum exemplo que possa mostrar uma absorção de elementos estrangeiros a sua figura. Apesar do caso acima citado das Lupercálias, mesmo nas moedas com Cleópatra, não vemos Marco Antônio se utilizando de adereços monárquicos ou que fizessem qualquer alusão do tipo, como já apontado anteriormente.

O segundo símbolo que podemos elencar é o clupeus virtutis. Ele foi um escudo de ouro que foi depositado na Cúria Júlia, onde se reunia o Senado, no qual se encontravam gravadas quatro virtudes possuídas por Augusto: virtus, pietas, clementia e iustitia. Galinsky aponta que o clupeus servia como meio de reforço da auctoritas de Augusto, ainda mais se tomarmos o fato de ter sido concedido pelos senadores, sendo um exemplo de reciprocidade e reconhecimento da liderança do herdeiro de César (GALINSKY, 1996, p.80).

O clupeus representava uma crença da restauração da moral e dos valores e simboliza uma ligação de Augusto com o passado, o presente e o futuro, sendo as quatro virtudes ali destacas importantes no contexto político e social pelo qual os romanos estavam passando (GALINSKY, 1996, p. 80-83). Foi um símbolo intimamente relacionado com a corona civica, por exaltar os bons feitos de Augusto em prol da República.

No que concerne às quatro virtudes apresentadas no clupeus, cabe uma breve explicação. A primeira delas é a virtus. Esta tinha principalmente uma conotação militar, relacionada ao papel da vitória em batalhas, mas também possuía uma face moral. Como Galinsky argumenta, no clupeus ela tinha o objetivo de reforçar a ação individual de Augusto com relação à República romana. A clementia era uma virtude relacionada à moderação com o inimigo e de reciprocidade entre duas partes, tendo sido uma virtude muito relacionada a ação desempenhada por César. A terceira virtude apontada pelas res gestae como presente no clupeus é a iustitia. Aqui podemos fazer um paralelo com Marco Antônio, mesmo que de modo indireto, pois essa virtude era característica de alguém que lutava contra as injustiças e as ilegalidades, tanto em esferas domésticas, quanto externas. A última e, segundo Galinsky, a mais importantes das virtudes era a pietas. Esta tinha uma forte ligação sobre a forma de agir de quem a possuía, pois perpassava pelas relações com a ciuitas e com o pater. Através dela, 
reforça-se a ligação entre Augusto e César e também a boa ação de Augusto contra Cleópatra em defesa da República. Contudo, ao observamos essas virtudes, como expõe o autor, não devemos tomá-las como cânones a serem seguidos pelos demais romanos ou príncipes, mas apenas como características do homenageado com a posse do clupeus, ou seja, Augusto (GALINSKY, 1996, p.84-88).

Como Zanker apresenta, o clupeus foi bastante utilizado por Augusto na construção de suas imagens, estando presente tanto em peças numismáticas, quanto em camafeus e outros objetos (ZANKER, 1988, p.92-98), estando até mesmo na ornamentação de seu mausoléu, segundo Pollini (2012. p.248-252). A primeira imagem abaixo (Imagem 11) nos trás uma cópia do que teria sido o clupeus de Augusto, sendo uma reprodução em mármore encontrada em Arles. Em seguida, temos uma de suas representações na numismática (Imagem 12), tendo ele sido também, como alguns exemplos nos foram legados, associado a outros elementos desse plano simbólico de Augusto, como, por exemplo, a Vitória.

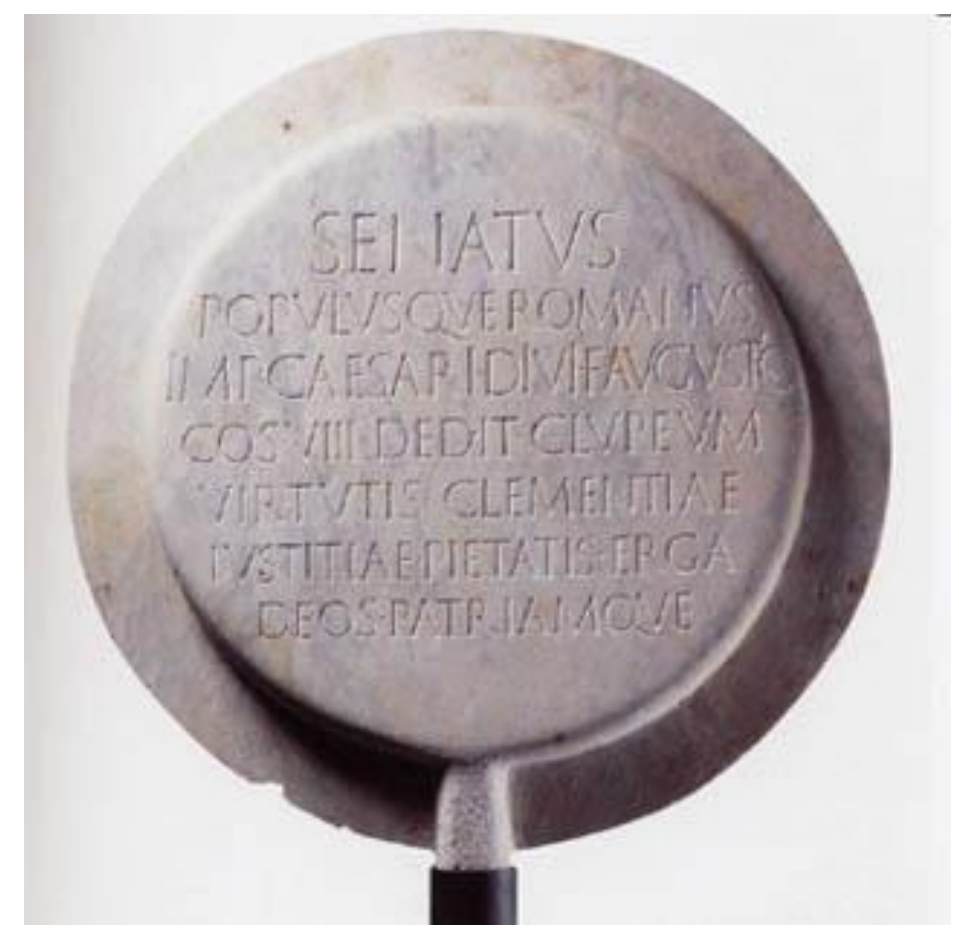

$\underline{\text { Imagem }} \underline{11}$ - Clupeus virtutis de Augusto; - escultura em mármore;

- Musée Lapidaire (Munique - Alemanha); 

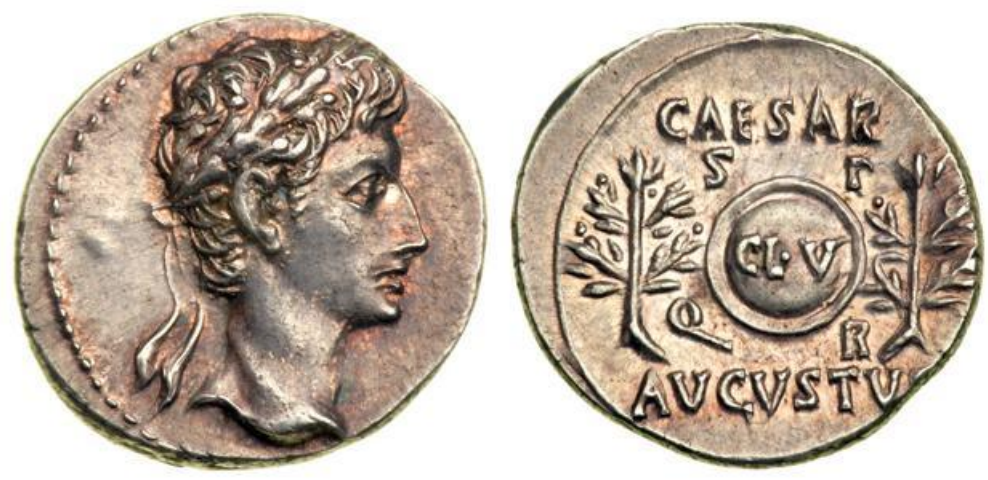

Imagem 12 - Moeda de Augusto (RIC 0036); - denário de prata; - cunhada entre 19 e 18 a.C.;

- Anverso: cabeça de Augusto;

- Reverso: CAESAR AUGUSTUS SPQR - Clupeus virtutis ao centro ladeado por ramos de louro;

O último dos símbolos que nos falta comentar é o título de Augustus. Com relação a ele, muito já se foi escrito. Como Galinsky aponta, a origem do nome remete a duas raízes etimológicas na língua latina, a primeira a augere, a qual se liga a palavra auctoritas, central na encenação do príncipe, ou seja, a influência ou a autoridade; e, segundo, a esfera religiosa, em que Augustus se torna sinônimo de bom augúrio (GALINSKY, 2012, p.66-68). Portanto, um símbolo que denota poder tanto numa esfera política, quanto num plano religioso. Suetônio, em sua biografia sobre Augusto nos apresenta a discussão existente sobre a adoção ou não do nome de Rômulo por Otaviano, até que Munácio Planco propôs Augusto (SUETÔNIO, Augusto, 7). A adoção do nome do fundador de Roma era perigosa, pois ele havia sido um rei, mesmo que a tradição legasse uma boa imagem dele como um governante que agiu em prol da Urbs. Como visto, a monarquia era mal vista e Otaviano havia acabado de vencer, de acordo com o seu discurso, uma ameaça monárquica representada por Cleópatra, o que o fazia não querer de modo algum se associar a algum elemento desses sistema político, mesmo que tendo sido pertencente ao passado romano.

$* * *$

Com o processo de uma maior centralização de muitas das atribuições das principais magistraturas republicanas nas mãos de homens de destaque na cena política romana no decorrer do século I a.C., era preferível que esta ao menos ocorresse nas mãos de alguém que soubesse manter a fachada republicana, ou seja, permitindo a continuação da aristocracia e do povo romano na ação política, conjuntamente com ele. Assim, este personagem não deveria tentar implantar em Roma um sistema político monárquico ou tirânico, mas se inserir na cena 
política romana sem ser um corpo estranho a ela. Foi o que ocorreu com Augusto. A República não voltou a ser o que havia sido nos séculos anteriores, até porque não estamos falando da mesma pequena região do Lácio sob o domínio das assembléias e magistraturas, mas sim de quase toda a bacia do Mediterrâneo sob dominação romana. A expansão territorial mostrou as limitações das estruturas políticas municipais para a gerência de um grande império, o que forçou o destacamento de alguém no seio dos magistrados romanos e este foi Augusto, que apesar da vitória militar e do apoio do exército, buscou legitimar seu poder junto às esferas políticas da Urbs, os senadores e o povo. Augusto procurou não se apresentar como estranho à República, mas sim como mais um dos senadores romanos, o que podemos ver até pela honra escolhida como a principal forma de se apresentar, a de princeps senatus. A centralização das incumbências políticas foi realizada como uma ação advinda de sua auctoritas, não de algo excepcional cedido a ele.

O estudo do comportamento social de Augusto se faz importante para se compreender a própria constituição do Principado. A etiqueta social instituída por Augusto, obviamente, teve que se adequar a própria situação de transição em que se encontrava a estrutura republicana romana, além de ser mais um dos elementos que compunham o cenário de restauração da República, pois não bastava expressar por palavras ou objetos e imagens que o mos maiorum romano estava sendo seguido e que a República estava sendo restabelecida. Era necessário que todos visualizassem na prática social aquilo que era disseminado pelo discurso augustano. A mise en scène era um artifício importante para que os demais cidadãos do império romano acreditassem que, de fato, Augusto não estava deturpando o poder dos patres e instaurando um governo pessoal.

Desse modo que observamos a ação de Augusto enquanto um civilis princeps, em que as recusas, as ações com relação ao senatus populusque romanus, o comprometimento com a manutenção da libertas, as ações enquanto um privatus e em conjunto com o officia amicorum, bem como a simplicidade de atuação e apresentação à sociedade e o patrocínio das artes, compõem a sua encenação política dentro da teatrocracia política. Ele não era mais do que um cidadão como os demais, porém, destacava-se apenas com relação a sua auctoritas, a qual, segundo ele mesmo, permitiu todas as honras que recebeu e, assim, o fizeram ser visto como diferente dos demais. A defesa da República foi um discurso significativo para que ele pudesse numa fase de adaptações da República romana se cristalizar enquanto um homem político diferente do jovem sem experiência nos eventos posteriores aos Idos de março. As honras, os cargos, os poderes e os símbolos do príncipe se inserem nesse cenário de construção e legitimação do Principado, em que Augusto é apresentado de modo ambíguo no 
seio da República romana, sendo um homem igual, mas diferente dos demais ao mesmo tempo.

Nesse contexto, a forma de ação com os elementos do exterior era importante, pois não deveria parecer que a adoção destes fosse uma ameaça aos costumes dos antepassados. A teatrocracia era encenada com a cultura romana e com os romanos, não com estrangeiros (claro que na prática de gerência das províncias isso não se aplicava por completo). Augusto não deveria se apropriar do modus vivendi exterior na composição de seu comportamento social. O mundo oriental se encontrava fora da teatrocracia política romana desejada. A adoção de um padrão de comportamento estrangeiro foi utilizada para descaracterizar Marco Antônio e fortalecer Otaviano/Augusto enquanto um bom romano, como observado anteriormente. A mise en scène do Principado era a de restauração e compromisso com a República, não sendo a figura de Augusto usada como suporte para uma deturpação da República e a associação de elementos externos, que quando realizados, como comum entre os romanos, foi relacionada à nova época em que a Urbs estava. Desse modo, a associação de Augusto a Apolo, o uso da lenda troiana de Enéias, a utilização da imagem de Alexandre Magno, dentre outros elementos, foram relacionados a Otaviano/Augusto com o cuidado de não se quebrar a encenação e o mos maiorum. Tudo que pudesse aludir a um referencial monárquico, como a coroa, os títulos ou mesmo o modo de agir em diversos campos de ação era evitado ou feito pelo viés romano, pela simbologia da própria cultura romana.

Portanto, mais do que apenas (des)construir os rivais Marco Antônio e Cleópatra, era necessário que Otaviano/Augusto também tomasse cuidado com a sua própria forma de agir politicamente, desde suas representações até os meios pelos quais atuava na cena política romana. Todos esses pontos estavam intimamente relacionados com o discurso de bem-feitor para com a República romana e com a experimentação do Principado romano. 


\section{CONSIDERAC ÕES FINAIS}

Apesar das considerações terem sido apresentadas de modo parcial ao final de cada capítulo, faz-se necessária uma retomada dos aspectos mais centrais de nosso exercício reflexivo no presente momento para que possamos ver os principais elementos da pesquisa de modo integrado neste último espaço de nossa leitura sobre os acontecimentos do passado. Nosso objeto de estudo foi observar como Otaviano/Augusto atuou politicamente em sua encenação de restauração da República e como esse discurso foi importante para o seu estabelecimento e sua manutenção na cena política romana durante sua vida política. Contudo, nosso prisma analítico foi analisar como os rivais, Marco Antônio e Cleópatra, e as relações com o mundo oriental foram inseridos nesse cenário e como a (des)construção dos retratos deles foi importante para a mise en scène de Otaviano/Augusto e o estabelecimento do Principado romano.

O Triunvirato romano foi uma fase política importante para que as bases do Principado romano fossem gestadas. Os anos de conturbada relação entre Otaviano e Marco Antônio permitiram, não somente que um líder surgisse no cenário político romano após a morte de César, apesar da frágil posição que ele ocupava, mas também que os temores de uma corrupção dos costumes dos antepassados fossem afastados através desse novo ator político que se dizia o defensor de Roma e o restaurador da República. Assim Otaviano procurou se apresentar à sociedade romana, sobretudo após os eventos de 36 a.C. (sua vitória contra Sexto Pompeu, a derrota de Marco Antônio perante os partos e a exclusão de Lépido do Triunvirato), em que a disputa passou a ser mais pessoal entre os dois dos três triúnviros que permaneceram nas atribuições políticas do Triunvirato.

Esse ano é central para que possamos entender o desenrolar dos anos seguintes e os desfechos realizados com o rompimento entre os dois antigos aliados de Triunvirato. As auctoritates deles se inverteram. Marco Antônio passou a ser acusado de ter se degenerado durante sua estadia no Oriente, onde estava desde 39 a.C., a partir da adoção de costumes 
comuns nessa região, como uma vida desregrada e a associação a outros deuses, como, por exemplo, Baco. No entanto, o amor por Cleópatra, que estaria levando o triúnviro a agir em prol dos egípcios, como reforçado a partir dos eventos de 34 a.C. (triunfo em Alexandria e doações de Alexandria) e da leitura de seu testamento em 32 a.C., o qual serviu de motivo para o definitivo rompimento da aliança e a declaração da guerra contra Cleópatra.

A maioria das análises historiográficas aborda as relações entre Marco Antônio e Otaviano, mas pouco se apropriam de como a construção de um discurso de um Marco Antônio nefasto à República foi significativo para Otaviano/Augusto em sua encenação política e para seu estabelecimento como um bom romano. As críticas de orientalização têm um contexto específico, como buscamos abordar em nossa pesquisa, e muito serviram como instrumento de engrandecimento de Otaviano/Augusto. Essa relação entre eu e outro também compôs o discurso de restauração da República engendrado por Otaviano/Augusto, por mais que em muitos aspectos apareça apenas de modo sutil e indireto. Marco Antônio foi mais do que um amigo e rival de Triunvirato, foi um personagem importante na composição da mise en scène de Otaviano/Augusto e muitos dos retratos que possuímos dele decorrem desse movimento de (des)construção de sua imagem.

Dentro desse quadro de disputa política entre os triúnviros, devemos inserir a rainha Cleópatra. Ela também fez parte desse discurso elaborado por Otaviano/Augusto de defensor da República. Como visto, mais do que apenas mostrar as ações e o comportamento degenerado de Marco Antônio no Oriente, era preciso também mostrar que a sua parceira política e esposa era inferior e uma ameaça à Urbs. Os estudos vêm buscando desconstruir o retrato que possuímos de Cleópatra, mostrando como ela foi traduzida no interior do mundo romano e como os séculos posteriores também se apropriaram de sua imagem. O foco principal, geralmente, é mostrá-la como uma mulher além das tintas dos autores antigos que a descreviam como uma mulher fatal. Para nós, o que mais nos foi significativo foi procurar compreender as razões que levaram, tanto na época de Otaviano/Augusto, quanto posteriormente, a trazê-la como um perigo a Roma. A batalha vencida em Actium foi declarada a ela, que foi colocada no posto de monstro que desejava governar sobre as ruínas do Capitólio. Desse modo, trazer Cleópatra como uma ameaça era justificar um confronto contra Marco Antônio, reforçar a acusação de sua degeneração e, ainda, colocar Otaviano/Augusto no papel do bom romano que protegia o povo, o Senado e os deuses romanos. O processo de tradução de Cleópatra à sociedade romana, em que o temor de uma dominação monárquica, principalmente sendo sua governante uma mulher pertencente a um 
arcabouço cultural diferente e visto como inferior ao romano, também compôs a cena da restauração republicana de Otaviano/Augusto.

No entanto, não apenas a (des)construção dos rivais deve ser trazida no objetivo de se entender a mise en scène de Otaviano/Augusto no interior da teatrocracia política existente na Roma do século I a.C.. O comportamento social dele também é um dos elementos que compõe o discurso de restauração republicana. De nada adiantaria apenas criticar Marco Antônio e Cleópatra se ele não procurasse agir de modo oposto àquele que se acusava ser o comportamento social deles. A historiografia muito abordou essa temática sobre a forma como Otaviano/Augusto se estabeleceu, manteve e legitimou no cenário político romano a partir da utilização de referenciais romanos ou ao modo romano. O Principado surgiu como uma experimentação, sendo uma adaptação da República a sua nova condição de um vasto território mediterrânico e com um magistrado superior aos demais em auctoritas. Os cargos, os poderes, as honras e os símbolos de Otaviano/Augusto se adequaram ao seu discurso de restauração e salvaguarda da República romana. Contudo, a sua ação enquanto um civilis princeps também teve como referencial o diálogo com elementos e com o modo de comportamento estrangeiro, principalmente oriental e das realidades monárquicas, mesmo que na maioria das vezes como negação, já que a visão de degeneração era uma atribuição a Marco Antônio.

Portanto, a 'restauração republicana' de Augusto deve ser trazida a análise dentro de sua característica complexidade. Primeiramente, porque o que ocorreu foi mais um retorno da ação política republicana do que uma restauração dos negócios públicos como existira antes do acirramento das querelas políticas entre os aristocratas romanos. Segundo, pelo fato de não apenas o príncipe ou os seus apoiadores serem tomados para sua análise, mas também todo o contexto no qual esse discurso foi elaborado. Assim, os problemas surgidos do desequilíbrio da relação entre Marco Antônio e Otaviano, ainda no contexto do Triunvirato, devem, como procuramos fazer em nosso exercício, ser apropriados para uma abordagem da mise en scène existida no Principado, pois os temores que justificaram a batalha fundacional do governo de Otaviano/Augusto e as honras a ele atribuídas em 27 a.C. permaneceram tendo ecos no modo de se atuar na cena política romana posterior. 


\section{ANEXO I}

\section{CRONOLOGIA}

63 a.C. - Nascimento de Otaviano;

51 a.C. - Ascensão de Cleópatra VII no trono egípcio;

48 a.C. - Morte de Pompeu e chegada de Júlio César em Alexandria;

Guerra alexandrina;

44 a.C. - Morte de Júlio César;

43 a.C. - Batalha de Módena;

Estabelecimento do acordo do Segundo Triunvirato;

42 a.C. - Batalha de Filipos;

Primeira reorganização do acordo do Triunvirato;

Ida de Marco Antônio para o Oriente;

41 a.C. - Batalha de Perúsia;

40 a.C. - Paz de Brindes - Segunda reorganização do acordo do Triunvirato;

Casamento de Marco Antônio com Otávia;

39 a.C. - Acordo de Miseno;

37 a.C. - Acordo de Tarento - Renovação do Triunvirato;

36 a.C. - Guerra contra Sexto Pompeu;

Guerra contra os partos;

Exclusão de Lépido do Triunvirato;

34 a.C. - Triunfo armênio e doações de Alexandria;

33 a.C. - Fim do Triunvirato;

32 a.C. - Leitura do testamento de Marco Antônio;

Declaração de guerra a Cleópatra;

Juramento dos italianos em apoio a Otaviano;

31 a.C. - Batalha de Actium;

30 a.C. - Conquista de Alexandria e do Egito;

Suicídios de Marco Antônio e Cleópatra;

29 a.C. - Triunfos de Otaviano em Roma;

27 a.C. - Devolução dos poderes de Otaviano ao Senado; 
Recebimento do título de Augustus, da corona civica e do clupeus uirtutis;

Divisão das províncias entre o príncipe e o Senado - recebimento do imperium;

23 a.C. - Poderes de Augusto: imperium proconsulare maius e tribunicia potestas;

14 d.C. - Morte de Augusto;

Ascensão de Tibério; 


\section{REFERÊNCIAS BIBLIOGRÁFICAS}

ALFÖLDY, Géza. A história social de Roma. Lisboa: Presença, 1989.

BALANDIER, Georges. O poder em cena. Brasília: Editora da Universidade de Brasília, 1980.

BALL, Warwick. Rome in the East: the transformation of an empire. London: Routledge, 2002.

BELAYCHE, Nicole. Rome: la Ville et le pouvoir. In: BELAYCHE, Nicole (dir.). Rome, les Césars et la Ville: aux deux prémiers siècles de notre ère. Rennes: Presse Universitaire de Rennes, 2001. p.I-XII.

BLOCH, Marc. Apologia da História. Rio de Janeiro: Jorge Zahar, 2002.

BRANIGAN, Keith. Hellenistic influences on the Roman world. In: WACHER, John (Ed.). The Roman world. Vol. I. Londres: Routledge, 2002. p.38-55.

BRAUND, David C.. The legacy of the Republic. In: WACHER, John (Ed.). The Roman world. Vol. I. Londres: Routledge, 2002. p.55-68.

BRUNT, Peter A. The army and the land in the Roman revolution. Journal of Roman Studies. 52. 1962. p.69-85.

La plebe romana. In: FINLEY, Moses. I. (ed.). Estudios sobre Historia Antigua. Madrid: Akal Editos, 1981. p.87-117.

BURKE, Peter. A fabricação do rei: a construção da imagem pública de Luís XIV. Rio de Janeiro: Jorge Zahar Editor, 1994.

Testemunha ocular. São Paulo: Edusc, 2004.

CAZENAVE, Michel; AUGUET, Roland. Os imperadores loucos: ensaio de mito-análise histórica. Mem Martins: Inquérito, 1995.

CAMOUS, Thierry. Orients/Occidents: vingt-cinq siècles de guerres. Paris: Presses Universitaires de France, 2007.

CÍCERO. Sobre a República. Tradução de Amador Cisneiros. Rio de Janeiro: Edições de Ouro, 1975.

CICERON. Discours contre Marc Antoine. Traduit par Héguin de Guerle. Paris: Librairie Garneir Frère, s/d.

CIZEK, Eugen. Histoire et historiens à Rome dans l'Antiquité. Lyon: Presses Universitaires de Lyon, 1995. 
CLÍMACO, Joana Campos. A representação dos reis ptolomeus do Egito segundo a tradição clássica. Anais do XXVI Simpósio Nacional de História - ANPUH. São Paulo, 2011. p.1-18.

CORASSIN, Maria Luiza. Sociedade e política na Roma antiga. São Paulo: Atual, 2001.

. Comentário sobre as Res Gestae Divi Avgvsti. Revista História. São Paulo, 2004, n.151, p.181-199.

CORBIER, Mireille. Poder e parentesco: a família Julio-Claudia. Clássica. São Paulo. 1992/1993, 5/6. p.167-203.

COSME, Pierre. Auguste. Paris: Editions Perrin, 2005.

CROOK, John A.. Political history, 30 BC to AD 14. In: BOWMAN, Alan K.; CHAMPLIN, Edward; LINTOTT, Andrew (eds.). The Cambridge Ancient History: The Augustan Empire, 43 B.C. - A.D 69. Tomo X. 2.ed. Cambridge: Cambridge University Press, 2001a. p.70-112.

Augustus: power, authority, achievement. In: BOWMAN, Alan K.; CHAMPLIN, Edward; LINTOTT, Andrew (eds.). The Cambridge Ancient History: The Augustan Empire, 43 B.C. - A.D 69. Tomo X. 2.ed. Cambridge: Cambridge University Press, 2001b. p.113-146.

DAVIAULT, André. Le 'mos maiorum'. In: GAILLARD, Jacques (org.). Rome $\boldsymbol{I}^{\text {er }}$ siècle av. J. C.: Ainsi périt la République des virtus.... Paris: Édition Autrement, 1996. p.58-71.

DAVIES, Penelope J. E.. Aegyptiaca in Rome: Adventus and Romanitas. In: GRUEN, Erich S. (ed.). Cultural Identity in the Ancient Mediterranean: Issues \& Debates. Los Angeles: Getty Research Institute, 2010. p.354-370.

DIO CASSIUS. Roman History. Translation by Earnest Cary. Londres: William Heinemann, 1955. (The Loeb Classical Library).

DION CASSIUS. Histoire romaine. Texte établi, traduit et annoté par Marie-Laure Freyburger et Jean-Michel Roddaz. Paris: Les Belles Lettres, 1991/4.

EDER, Walter. Augustus and the power of tradition. In: GALINSKY, Karl (org.). The Cambridge companion to the Age of Augustus. New York: Cambridge University Press, 2005. p.13-32.

ERSKINE, Andrew. Hellenistic Monarchy and Roman Political Invective. The Classical Quartely. Cambridge, 1991, p.106-120.

FINLEY, Moses I.. Aspectos da Antiguidade. São Paulo: Martins Fontes, 1991.

GALINSKY, Karl. Augustan culture: an interpretive introduction. New Jersey: Princeton University Press, 1996. 
Introduction. In: GALINSKY, Karl (org.). The Cambridge companion to the Age of Augustus. New York: Cambridge University Press, 2005. p.5-12.

. Augustus: an introduction to life of an emperor. Cambridge: Cambridge University Press, 2013.

GEERTZ, Clifford. A interpretação das culturas. Rio de Janeiro: Zahar Ed., 1978.

GRIMAL, Pierre. A civilização romana. Lisboa: Edições 70, 1993.

GRUEN, Erich. Greeks and non-Greeks. In: BUGH, Gleen R. (ed.). The Cambridge companion to Hellenistic World. New York: Cambridge University Press, 2006. p.295-314. 2011.

HAHM, David E.. Kings and constitutions: Hellenistic theories. In: ROWE, Christopher; SCHOFIELD, Malcom. The Cambridge History of Greek and Roman Political Thought. New York: Cambridge University Press, 2008. p.457-476.

HAMMOND, Mason. Hellenistic influences on the structure of Augustus principate. Memoirs of the American Academy in Rome. Vol. 17, 1940. p.1-25.

HARTOG, François. O espelho de Heródoto: ensaio sobre a representação do outro. Belo Horizonte: Editora UFMG, 1999.

HASSALL, Mark. Romans and non-Romans. In: WACHER, John (ed.). The Roman world. Vol. II. Londres: Routledge, 2002. p.685-700.

HENTSCH, Thierry. L'Orient imaginaire: la vision politique occidentale de l'Est méditerranéen. Paris: Les Éditions de Minuit, 1988.

HOBSON, John M.. The Eastern origins of Western civilisation. Cambridge: Cambridge University Press, 2004.

HÖLBL, Günther. A history of the Ptolemaic empire. New York: Routledge, 2001.

HORACE. Odes et épodes. Texte établi et traduit par F. Villeneuve. Paris: Les Belles Lettres, 1946.

HUGHES-HALLETT, Lucy. Cleópatra: histórias, sonhos e distorções. Rio de Janeiro: Record, 2005.

KOSELLECK, Reinhart. Futuro passado: Contribuição à semântica dos tempos históricos. Rio de Janeiro: Contraponto, 2011.

LE GOFF, Jacques. Monumento/Documento. In: História e Memória. São Paulo: Editora da Unicamp, 2003. p.525-541. 
LÉVÊQUE, Pierre. O mundo helenístico. Lisboa: Edições 70, 1987.

MACRÓBIO. Saturnalia. Tradução de R. A. Kaster. Cambridge: Harvard University (Loeb), 2011.

MEIER, Christian. C. Caesar Divi filius and the formation of alternative in Rome. In: RAAFLAUB, Kurt A.; TOHER, Mark (eds). Between Republic and Empire: Interpretations of Augustus and his Principate. London: University of California Press, 1993. p.54-70.

MILLAR, Fergus. Some speeches in Cassius Dio. Museum Helveticum. Vol. 18. 1961, p.1122. 67 .

Triumvirate and Principate. The Journal of Roman Studies. Vol. 63. 1973. p.50-

State and subject: the impact of monarchy. In: MILLAR, Fergus; SEGAL, Erich. Caesar Augustus: seven aspects. New York: Clarendon Press, 1984. p.37-60.

MOMIGLIANO, Arnaldo. Os limites da helenização: a interação cultural das civilizações grega, romana, céltica, judaica e persa. Rio de Janeiro: Jorge Zahar, 1991.

NERAUDAU, Jean Pierre. Auguste: La brique et le marbre. Paris: Belles Lettres, 1996.

NICOLET, Claude. Rome et la conquete du monde mediterranéen. Paris: Press Universitaires de France, 1979.

. O cidadão e o político. In: GIARDINA, Andrea (org.). O homem romano. Lisboa: Presença, 1992. p.21-48.

PELLING, Christopher. The triumviral period. In: BOWMAN, Alan K.; CHAMPLIN, Edward; LINTOTT, Andrew (eds.). The Cambridge Ancient History: The Augustan Empire, 43 B.C. - A.D 69. Tomo X. 2.ed. Cambridge: Cambridge University Press, 2001. p.1-69.

PESAVENTO, Sandra J. Cidades visíveis, cidades sensíveis, cidades imaginárias. Revista Brasileira de História. São Paulo, 2007, v.27, n.53, p.11-23.

PLUTARQUE. Vies. Texte établi et traduit par Robert Flacelière et Emile Chambry. Paris: Les Belles Lettres, 1977.

POLÍBIO. História. Tradução de Mario da Gama Kury. Brasília: Editora da Universidade de Brasília, 1985.

POLLINI, John. From Republic to Empire: Rhetoric, Religion, and Power in the Visual Culture of Ancient Rome. Oklahoma: University of Oklahoma Press, 2012.

PROPERCE. Élégies. Texte établi et traduit par D. Paganelli. Paris: Les Belles Lettres, 1947. 
REINHOLD, M.; SWAN, P. M.. Cassius Dio's assessments of Augustus. In: RAAFLAUB, Kurt A.; TOHER, Mark (eds). Between Republic and Empire: Interpretations of Augustus and his Principate. London: University of California Press, 1993. p.155-173.

Res Gestae Divi Augusti. In: A Vida e os Feitos do Divino Augusto / textos de Suetônio e Augusto. Tradução de Matheus Trevizam; Antonio Martinez de Rezende. Belo Horizonte: Editora UFMG, 2007.

. Tradução e comentários G. D. Leoni. São Paulo: Nobel, 1957.

ex monvmentis Ancyrano et Antiocheno Latinis Ancyrano et Apolloniensi Graecis. Texte établi et commenté par Jean Gagé. Paris: Les Belles Lettres, 1935.

RICHTER, Gisela M. A.; BRECKENRIDGE, J. D. The relation of early Imperial Rome to Greek art. In: HAASE, Wolfgang; TEMPORINI, Hildegard (eds.). Aufstieg und Niedergang der Römischen Welt. II. 12.1. Berlin / New York: Walter de Gruyter, 1982. p.3-23.

RIVERO, Pilar. A política externa de Cleópatra VII Filopátor. In: FUNARI, Pedro Paulo A. Amor, desejo e poder na Antiguidade: relações de gêneros e representações do feminino. Campinas: Editora da Unicamp, 2003. p.95-105.

SAID, Edward W.. Orientalismo: O Oriente como invenção do Ocidente. São Paulo: Companhia das Letras, 2007.

SALÚSTIO. Conjuração de Catilina. Tradução de Antônio da Silveira Mendonça. Petrópolis: Vozes, 1990.

SARTRE, Maurice. L'Orient Romain: Provinces et Société Provinciales en Méditerranée Orientale d'Auguste aux Sévères (31 avant J.-C. - 235 après $J$.-C.). Paris: Éditions du Seuil, 1991.

SCHEID, John. Du princeps à l'empereur. In: JACQUES, François; SCHEID, John. Rome et l'integration de l'Empire (44 av. J.C. - 260 ap. J.C.). tome I - Les structures de l'empire romain. Paris: Nouvelle Clio, 1990. p.1-46.

SCHNEIDER, Rolf Michael. The making of Oriental Rome: shaping the Trojan legend. In: BANG, Peter Fibiger; KOLODZIEJCZYK, Dariusz (eds.). Universal Empire: $a$ comparative approach to Imperial Culture and representation in Eurasian History. Cambridge: Cambridge University Press, 2012. p.76-129.

SCHWENTZEL, Christian-Georges. Cleópatra. Porto Alegre: L\&PM, 2009.

SEBASTIANI, Breno B.. A política como objeto de estudo: Tito Lívio e o pensamento historiográfico romano do século I a.C. In: JOLY, Fábio Duarte (org.). História e Retórica: Ensaios sobre historiografia antiga. São Paulo: Alameda, 2007. p.77-96.

SILVA, Camila Ferreira Paulino da. A construção da imagem de Otávio, Cleópatra e Marco Antônio entre moedas e poemas (44 a 27 a.C.). 2014. 189f. Dissertação (Mestrado em História). Universidade Federal do Espírito Santo, Vitória, 2014. 
SILVA, Érica Cristhyane Morais da. A helenização de Roma: convergências e impasses. In: SILVA, Gilvan Ventura da (org.) Grécia, Roma e Oriente: da crise da pólis a época helenística (404-31 a.C.). Vitória: Flor\&cultura, 2009. p.139-164.

STRABON. Géographie. Livres V et VI. Texte établi et traduit par François Lassere. Paris: Les Belles Lettres, 1967.

SUETÔNIO. A vida dos doze Césares. Tradução de Sady-Garibaldi. Rio de Janeiro: Ediouro, s/d.

TÁCITO. Anais. Tradução de Leopoldo Pereira. Rio de Janeiro: Edições de ouro. 1977.

TITE-LIVE. Histoire Romaine. Introduction par Jean Bayet et traduction par Gaston Baillet Paris: Les Belles Lettres, 1947.

TOHER, Mark. Augustus and the evolution of Roman historiography. In: RAAFLAUB, Kurt A.; TOHER, Mark (eds). Between Republic and Empire: Interpretations of Augustus and his Principate. London: University of California Press, 1993. p.139-154.

TURCAN, Robert. Les cultes orientaux dans le monde romain. Paris: Les Belles Lettres, 1989.

VIRGÍLIO. Eneida. Tradução de Manuel Odorico Mendes. Campinas: Atelie Editorial/Ed. Unicamp, 2005.

VLASSOPOULOS, Kostas. Unthinking the Greek Polis: Ancient Greek History Beyond Eurocentrism. Cambridge/New York: Cambridge University Press, 2007.

WALBANK, F. W.. Monarchies and monarchic ideas. In: WALBANK, F. W.; ASTIN, A. E. (eds.). The Cambridge Ancient History: The Hellenistic World. Tomo VII, Parte I. 2.ed. Cambridge: Cambridge University Press, 1984. p.62-100.

WALLACE-HADRILL, Andrew. Civilis Princeps: Between Citizen and King. The Journal of Roman Studies. Vol.72. 1982. p.32-48.

Arcs de triomphe romains et honneurs grecs: la langage du pouvoir à Rome. In: BELAYCHE, Nicole (dir.). Rome, les Césars et la Ville: aux deux prémiers siècles de notre ère. Rennes: Presse Universitaire de Rennes, 2001. p.51-84.

Rome's Cultural Revolution. Cambridge: Cambridge University Press, 2008.

WOOLF, Greg. Saving the barbarian. In: GRUEN, Erich S. (ed.). Cultural Identity in the Ancient Mediterranean: Issues \& Debates. Los Angeles: Getty Research Institute, 2010. p.255-271.

YAVETZ, Zvi. The res gestae and Augustus' public image. In: MILLAR, Fergus; SEGAL, Erich. Caesar Augustus: seven aspects. New York: Clarendon Press, 1984. p.1-36.

ZANKER, Paul. The power of images in the age of Augustus. Ann Arbor: The University of Michigan Press. 1988. 